\title{
Recent Advances in Antigen-Specific Immunotherapies for the Treatment of Multiple Sclerosis
}

\author{
Olga Kammona ${ }^{1}$ and Costas Kiparissides ${ }^{1,2, *}$ \\ 1 Chemical Process and Energy Resources Institute, Centre for Research and Technology Hellas, \\ P.O. Box 60361, 57001 Thessaloniki, Greece; kammona@cperi.certh.gr \\ 2 Department of Chemical Engineering, Aristotle University of Thessaloniki, 54124 Thessaloniki, Greece \\ * Correspondence: costas.lpre@cperi.certh.gr
}

Received: 5 May 2020; Accepted: 26 May 2020; Published: 29 May 2020

\begin{abstract}
Multiple sclerosis (MS) is an autoimmune disease of the central nervous system and is considered to be the leading non-traumatic cause of neurological disability in young adults. Current treatments for MS comprise long-term immunosuppressant drugs and disease-modifying therapies (DMTs) designed to alter its progress with the enhanced risk of severe side effects. The Holy Grail for the treatment of MS is to specifically suppress the disease while at the same time allow the immune system to be functionally active against infectious diseases and malignancy. This could be achieved via the development of immunotherapies designed to specifically suppress immune responses to self-antigens (e.g., myelin antigens). The present study attempts to highlight the various antigen-specific immunotherapies developed so far for the treatment of multiple sclerosis (e.g., vaccination with myelin-derived peptides/proteins, plasmid DNA encoding myelin epitopes, tolerogenic dendritic cells pulsed with encephalitogenic epitopes of myelin proteins, attenuated autologous $\mathrm{T}$ cells specific for myelin antigens, $\mathrm{T}$ cell receptor peptides, carriers loaded/conjugated with myelin immunodominant peptides, etc.), focusing on the outcome of their recent preclinical and clinical evaluation, and to shed light on the mechanisms involved in the immunopathogenesis and treatment of multiple sclerosis.
\end{abstract}

Keywords: multiple sclerosis; autoimmune diseases; antigen-specific immunotherapies; tolerogenic vaccines; tolerance induction; central nervous system; myelin peptides; myelin basic protei; proteolipid protein; myelin oligodendrocyte glycoprotein

\section{Introduction}

Multiple sclerosis (MS) is a chronic inflammatory disease of the central nervous system (CNS) caused by genetically-predisposed hosts by infectious and environmental factors which induce complex autoimmune responses in the CNS resulting in degeneration of the myelin sheath and axonal loss in the brain and spinal cord [1-14] It is the most prominent demyelinating disease leading to progressive clinical disability in MS patients $[5,6,15]$ due to ineffective remyelination $[13,15]$. More than 2 million people worldwide suffer from MS and it is considered as the leading non-traumatic cause of neurological disability in young adults with a disease onset commonly around 20 and 40 years of age $[4,6,15,16]$. High prevalence of the disease is reported in North America and Europe [15].

MS exhibits a vastly heterogeneous clinical course $[6,17]$ which varies from a benign disease course that doesn't lead to serious disability, demonstrated by $10-15 \%$ of MS patients, to aggressive forms of the disease leading to severe disability and even paralysis. The increased heterogeneity of the disease severity strongly affects the design and duration of therapeutic schemes administered to MS patients [17]. 
MS features the following stages: a pre-clinical stage, namely, a radiologically-isolated syndrome (RIS), which is then demonstrated as a clinically-isolated syndrome (CIS) [2,3], followed by a relapsing remitting stage (RRMS) which may later advance into secondary progressive disease (SPMS) $[2,4,6,16,18]$. It should be noted that a minority of MS patients (e.g., 10-15\% [3,6,16]) exhibit progressive MS from the disease onset, known as primary progressive MS (PPMS) [2,4,6,18] (Figure 1). The aforementioned classification corresponds to the inflammatory image of MS which can be detected via magnetic resonance imaging $(\mathrm{MRI})[2,16]$.

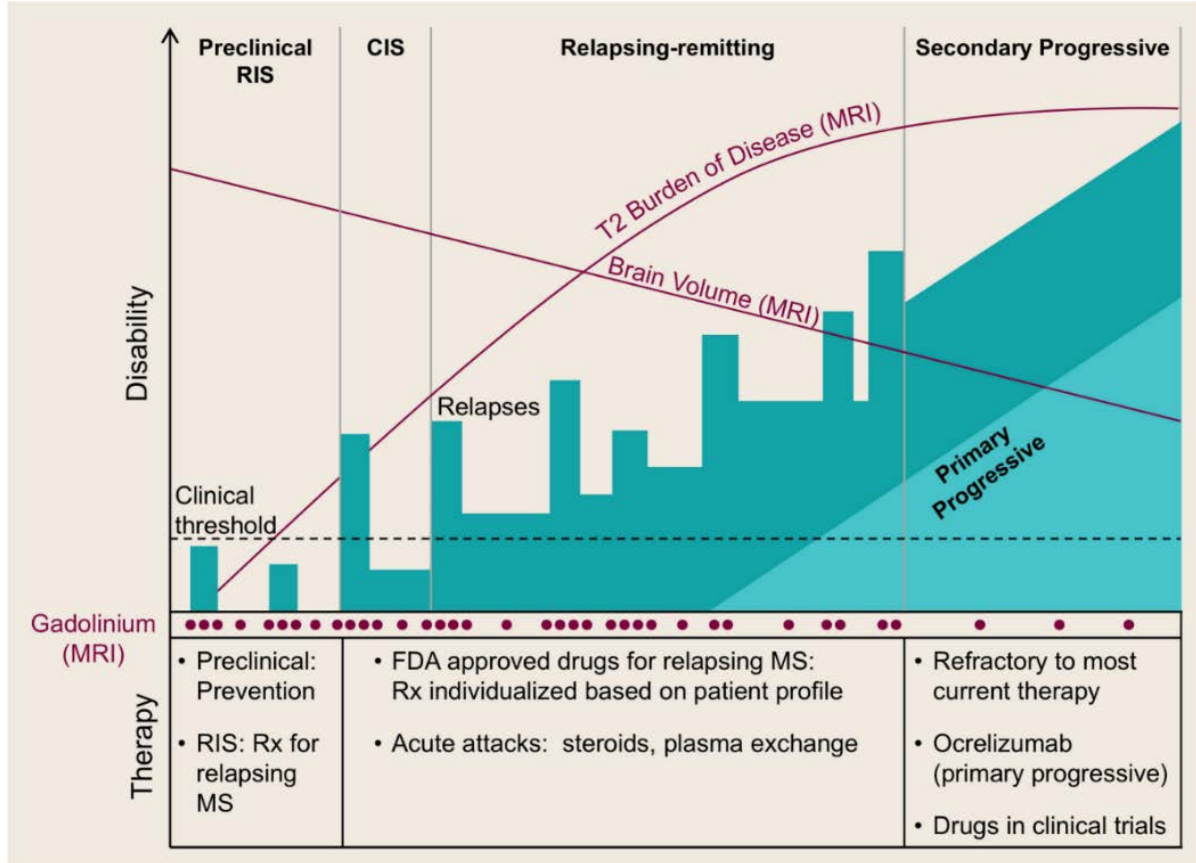

Figure 1. Stages of multiple sclerosis (MS). RIS: radiologically isolated syndrome; CIS: clinically isolated syndrome; FDA: U.S. food and drug administration (with the permission of [2]).

RRMS affects approximately $85 \%$ of MS patients $[3,6,19]$ of whom women are twice as many as men [6]. It is characterized by periods of relapses (i.e., episodes of neurologic dysfunction, such as sensory disturbances, optic neuritis, or disturbances of motor/cerebellar function) followed by remission periods (i.e., periods of partial or full clinical recovery) $[2,3,6,14,16]$. Relapses coincide with CNS inflammation/demyelination visualized by MRI as lesions found mainly in the white matter [3]. In the majority of patients, RRMS advances to SPMS [16] within 10-20 years after diagnosis [3,6].

RRMS involves the movement of immune cells from the peripheral sites to the CNS (mainly in the white matter, even though extensive number of demyelinated plaques can be located in the grey matter [20]) resulting in the formation of localized inflammatory sites. Inflammatory processes in these sites induce killing of oligodendrocytes, myelin damage, and axon injury and loss, resulting in impaired neurological function [20]. On the other hand, the progressive disease implicates the generation of a pathological process within the brain [2]. Thus, the characteristic feature of SPMS is no longer the inflammatory lesions but an atrophic brain attributed to enhanced loss of axons, cortical demyelination, activation of microglia, and inefficient remyelination [2,3]. SPMS patients demonstrate progressive neurological dysfunction resulting in enhanced physical disability (e.g., inability to walk) [2,3].

PPMS is also characterized by gradual neurological decline without relapses [3,6]. In comparison with RRMS, the disease onset for PPMS is usually ten years later and it does not exhibit female predominance [6]. To date, clinical evidence shows significant differences between RRMS and progressive MS [21], reflected by the diverse response to currently existing treatments, but not between SPMS and PPMS. [18]. 
Currently, there is no cure for MS. Some existing treatments appear to be beneficial for patients with RRMS. However, there is still a lack of effective therapies for the progressive forms of MS [2].

The present paper aims to extensively review the different, recently developed myelin antigen-specific strategies (e.g., myelin peptide based vaccination, vaccination with plasmid DNA encoding myelin epitopes, tolerogenic dendritic cells pulsed with encephalitogenic epitopes of myelin proteins, vaccination with attenuated autologous $\mathrm{T}$ cells specific for myelin antigens, $\mathrm{T}$ cell receptor vaccination, carrier-aided administration of myelin immunodominant peptides, etc.) for the prevention/treatment of MS, especially with respect to their in vivo and clinical evaluation outcomes and the challenges they face in order to be translated to MS patients. It also seeks to unravel the mechanisms involved in the immunopathogenesis of the relapsing remitting and progressive MS, as well as the mechanisms of action of the developed tolerance-inducing vaccines.

The different antigen-specific immunotherapies are analytically presented in a comparative manner in separate tables providing detailed information about the selected myelin antigen, the vaccination strategy (e.g., prophylactic, preclinical, therapeutic), the administration route (e.g., intravenous, subcutaneous, intraperitoneal, epicutaneous, intradermal, oral, nasal, pulmonary) and the administered dose, the cell type (e.g., tolerogenic dendritic cells, $\mathrm{T}$ cells, hematopoietic stem cells, bone marrow cells) and the inductive agent, the carrier type (e.g., polymer particles, soluble antigen arrays, immune polyelectrolyte multilayers, inorganic particles, pMHC-NPs, mannan-conjugated myelin peptides, liposomes, exosomes, antigen-presenting yeast cells), and its characteristics (e.g., size, zeta potential, antigen loading), as well as the vaccination outcome.

The review paper is based on a systematic search of PubMed using the following search terms: multiple sclerosis, antigen-specific immunotherapies, tolerogenic vaccines, nanocarriers, nanomedicine, DNA vaccination, cell-based vaccination, clinical trials. The search covered the time period from 1 January 2000 till today. Publications addressing pre-clinical and clinical evaluation of antigen-specific immunotherapies for multiple sclerosis were selected for inclusion.

\section{Immunopathogenesis of MS}

Successful preclinical studies and clinical trials for MS which target cells and molecules of the immune system support the idea that the latter has a dominant role in the pathogenesis of MS. These studies have proposed that cells of the adaptive immune system like B cells and various effector $T$ cells, combined with cells of the innate immune system such as natural killer cells and microglia, uniquely contribute to the disease [2]. However, it should be mentioned that while the peripheral adaptive immune system (T lymphocytes) is the primary driver of RRMS, the innate immune system (microglia and astrocytes) together with B lymphocytes is considered to drive progressive MS [2]. The CNS of MS patients has been also found to exhibit infiltration of activated T cells, B cells, plasma cells, dendritic cells (DCs), and macrophages indicating the contribution of both cellular and humoral (i.e., antibody-mediated) immune responses as well as of various immunopathological effector mechanisms to the damage of CNS tissue [22,23].

It has been suggested that two independent types of inflammation, developing in parallel, can occur in multiple sclerosis patients. The first one is related with the focal invasion of $\mathrm{T}$ and $\mathrm{B}$ cells through $B B B$ leakage, giving rise to classic active demyelinated plaques in the white matter. The second one deals with a slow accumulation of $\mathrm{T}$ and $\mathrm{B}$ lymphocytes without profound BBB damage in the perivascular Virchow Robin spaces and the meninges, where they form cellular aggregates resembling, in most severe cases, tertiary lymph follicles. The latter can be linked with the development of demyelinated lesions in the cerebral and cerebellar cortex, slow expansion of existing lesions in the white matter, and diffuse neurodegeneration in normal-appearing white and/or grey matter [18]. The presence of the lymphoid follicle-like structures (follicle-like ectopic germinal centers) in the inflamed cerebral meninges of some SPMS patients could indicate that B-cell maturation is sustained locally in the CNS and contributes to the induction of a compartmentalized humoral immune response [2,22]. 
The role of the various immune cells and the immunopathological effector mechanisms contributing to the development of MS are discussed below.

The ability of the human immune system to respond to an enormous number of encountered antigens comes with the risk that some T cells will be able to recognize self-antigens, such as CNS (e.g., myelin) antigens. Most autoreactive T lymphocytes are usually deleted in the thymus via a process known as negative selection (central tolerance). However, a number of these $T$ cells escape from the thymus to peripheral sites where they are normally kept under control by mechanisms of peripheral tolerance. If these mechanisms fail, due to reduced action of regulatory $\mathrm{T}$ cells and/or enhanced resistance of effector $\mathrm{T}$ and $\mathrm{B}$ lymphocytes to suppression, autoreactive $\mathrm{T}$ cells recognizing CNS antigens are activated in the peripheral lymphoid system to become effector cells, via molecular mimicry (i.e., activation by a viral peptide having sufficient sequence similarity [24] or otherwise sharing an immunologic epitope [25] with the CNS antigen), recognition of CNS proteins released in the periphery, presentation of new autoantigens and bystander activation (i.e., $\mathrm{T}$ cell receptor (TCR)-independent and cytokine-dependent activation probably due to viral infection [26]). Then the activated $T$ cells (CD8+ T cells, and CD4+ T cells differentiate to T helper 1 (Th1) and Th17 cells) together with $\mathrm{B}$ cells and monocytes (cells of the innate immune system) infiltrate the CNS by crossing the blood-brain barrier (BBB) leading to inflammation. There, they are reactivated via encountered resident antigen presenting cells, APCs (e.g., microglial cells) and infiltrating APCs (e.g., dendritic cells, macrophages) presenting CNS autoantigens on the major histocompatibility complex, MHC (also known as human leucocyte antigen, HLA, in humans [11]) molecules. Specifically, CD4+ T cells interact with MHC II expressing cells, like dendritic cells, macrophages and B cells, whereas CD8+ T cells directly interact with MHC I/antigen-expressing cells, like neurons and oligodendrocytes. It should be noted that MHC class II is adequately expressed only on professional APCs, while MHC class I is expressed by all cell types in the CNS inflammatory milieu. Therefore, CD4+ T cells are mainly found in perivascular cuffs, and meninges, whereas CD8 $+\mathrm{T}$ cells additionally infiltrate the parenchyma of the irritated lesions. Upon contact with their cognate antigen, $\mathrm{CD} 4+\mathrm{T}$ cells are thought to secrete cytokines and immune mediators resulting in the attraction of resident immune cells like microglia, macrophages and astrocytes, secretion of proinflammatory cytokines, enhanced APC function, and increased production of reactive oxygen and nitrogen species (ROS/RNS). On the other hand, apart from secreting inflammatory mediators, CD8 $+\mathrm{T}$ cells directly attack oligodendrocytes and neurons, thus causing oligodendrocyte death (e.g., via secretion of granzymes and perforin leading to pore formation and stimulation of programmed cell death [2]) and neuronal damage (e.g., release of cytolytic granules leading to axonal dissection [2]) (Figure 2). The above result in inflammation, myelin loss, and axonal injury. This inflammatory cascade leads to the recruitment of monocytes and macrophages into the lesion resulting in the release of more CNS antigens and their presentation to potentially autoreactive $\mathrm{T}$ cells. It should be mentioned that epitope spreading could result in a broader autoimmune response involving additional autoantigens [1-3,11,27-33].

$\mathrm{CD} 4+\mathrm{T}$ cells are considered to have a paramount role in the immunopathogenesis of MS due to the secretion of interferon gamma (IFN $\gamma$ ) and IL-17 [2,20,34]. However, it has been lately revealed that CD8+ $\mathrm{T}$ cells are also responsible for the initiation of human MS pathogenesis where, contrary to experimental autoimune encephalomyelitis (EAE), CD8+ T cells are the predominant T lymphocyte infiltrate in acute and chronic MS lesions [1,2]. Compared with CD4+ T cells, CD8+ T cells can be found more frequently in the white matter and in the cortical demyelinating lesions in the grey matter, and their density can be closely correlated with axonal damage [1,3]. Epitope spreading, assisted by cross-presentation of antigens by monocyte-derived DCs, has been found to activate myelin-specific CD8+ T cells also in an EAE model [3]. It has been suggested that CD8+ T cells remain in the CNS (e.g., brain and spinal cord) as tissue-resident cells, and upon re-encounter of their cognate antigen, focally propagate neuroinflammation [18].

Despite the fact that MS is considered a T lymphocyte-mediated disease [35], the important results of anti-CD20 therapy (e.g., rituximab, ocrelizumab) in MS indicate a significant role for B cells in its 
pathogenesis. B cells can have either a pro- or an anti-inflammatory role, based on their subtype and context. Their pro-inflammatory functions, comprise critical antigen presentation in the context of MHC class II molecules to Th17 and Th1 cells, secretion of pro-inflammatory cytokines (e.g., tumor necrosis factor alpha, TNF- $\alpha$, interleukin-6 (IL-6) and granulocyte-macrophage colony-stimulating factor, GM-CSF) that promote CNS inflammation and propagate demyelination and neurodegeneration, and production of antibodies [36]. B lymphocytes can traffic out of the CNS to the cervical lymph nodes where they can undergo affinity maturation and then re-enter the CNS and promote further damage [3].

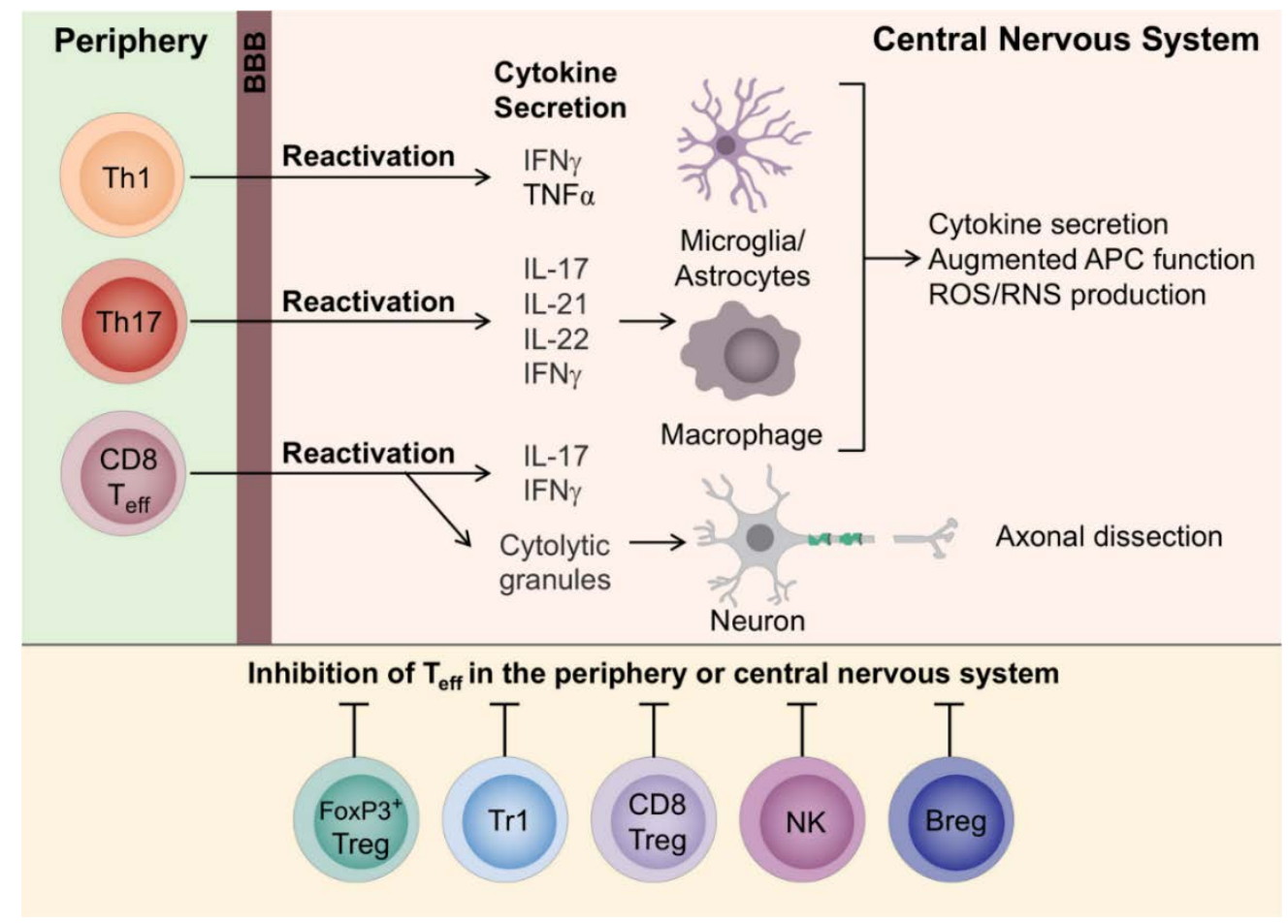

Figure 2. Effector T cells in multiple sclerosis (with the permission of [2]).

B cells are considered a unique population of APCs since, in contrast to other APCs which recognize various exogenous and endogenous antigens, B cells are highly selective (i.e., they specifically recognize only the antigens that are bound to their unique surface B cell receptor). Studies with the EAE model have indicated that some autoantigens, like the highly immunogenic myelin oligodendrocyte glycoprotein (MOG), require their presentation by B cells to activate CD4+ T cells. Accordingly, it can be speculated that the antigen(s) which trigger human MS are likewise B cell dependent [36]. Furthermore, active genes in B cells represent a major component of more than 200 variants known to increase the risk for developing MS. Remarkably, the gene that encodes the MHC class II DR $\beta$ chain, which is known to be critical for APC function, is considered, genome-wide, the strongest MS predisposition signal. Probably, the net effect of this genetic burden is biased biology of B cells towards a pro-inflammatory phenotype, which promotes the presentation of self-antigens to effector $\mathrm{T}$ cells or augments the autoimmune responses through the production of cytokines and other immune mediators [36].

Regulatory T cells (CD4 FoxP3+ Tregs, CD4+ Tr1 regulatory cells, CD8 Tregs), regulatory B cells (Breg) cells and natural killer cells (NK cells) can achieve regulation of effector $\mathrm{T}$ cells in the peripheral lymphoid tissue or in the CNS. CD4 FoxP3+ Tregs $(<4 \%$ of circulating CD4 T cells) express the transcription factor Forkhead box protein 3 (FoxP3) along with numerous inhibitory checkpoint molecules on their surface. They are activated by self-antigens and they suppress the activation of other cell types through a mechanism that requires cell contact [37]. CD4+ Tr1 regulatory cells impede 
cell proliferation mainly via the secretion of IL-10 [38]. Both Tregs are considered important in MS due to the exhibition of unique characteristics. Subsets of CD8+ Tregs that have been indicated to suppress immune responses and disease progression via distinct mechanisms have been identified by a unique expression of molecules like CD122, CD28, CD102 and HLA-G [2,39,40]. In addition, Th2 cells secreting cytokines like IL-4, IL-5, and IL-13, are considered to be able to downregulate the activity of pro-inflammatory cells [27]. B cells can also regulate various B and $\mathrm{T}$ cell mediated effector immune functions via secretion of regulatory cytokines IL-10 and IL-35, transforming growth factor beta (TGF- $\beta$ ), or programmed death-ligand 1 (PD-L1). Specifically, IL-10 secreting B-regs inhibit pro-inflammatory T cell responses, partly mediated via IFN $\gamma$ and IL17 [2,3,36]. Finally, NK cells are known to suppress immune responses via killing activated, possibly pathogenic, CD4+ T cells.

Immune-modulatory networks are triggered in parallel with the deleterious activity of effector $\mathrm{T}$ cells, in order to limit CNS inflammation and initiate tissue repair, resulting in partial remyelination. The modulation of immune activation can be associated with clinical remission. However, it should be mentioned that in the absence of treatment, suppression of autoimmunity cannot be fully achieved. Consequently, additional attacks will normally lead to the progressive form of MS [2]. The action of autoreactive $\mathrm{T}$ and $\mathrm{B}$ cells in MS could be owed to the defective function of regulatory cells. Disease-associated HLA class II variants might skew the selection in the thymus so that the regulatory $\mathrm{T}$ cells which are released into the peripheral sites cannot adequately suppress autoreactive effector $\mathrm{T}$ cells [3].

\section{MS Therapies}

\subsection{Disease-Modifying Therapies}

Current treatments for MS can be categorized into long-term immunosuppressant drugs, which have significant risks for various infections and cancer, and disease-modifying therapies (DMTs) designed to alter the progress of the disease via interference with $\mathrm{B}$ and $\mathrm{T}$ cells activity, and reduction of BBB disruption. For example, the more recently engineered monoclonal antibodies (mAbs) act via blocking $\alpha 4$ integrin interactions (e.g., natalizumab) or lysing immune cells exhibiting surface markers like CD20 (ocrelizumab, ofatumumab) [41] or CD52 (alemtuzumab). Due to their different mechanisms of action (Figure 3), DMTs' efficacy and safety profiles [42] vary significantly. Presently, there exist more than 10 FDA (U.S. Food and Drug Administration) approved DMTs for RRMS aiming to reduce relapse level and severity of inflammation in CNS. DMTs can be classified based on the administration route as intravenous, self-injectable and oral formulations (Table 1) [16,23,31,43-49].

Among the FDA-approved DMTs, ocrelizumab, alemtuzumab and natalizumab seem to have the highest anti-inflammatory effect and to efficiently reduce relapses as proven by MRI scans $[2,50]$. Another approach for the treatment of MS involves the use of low-dose interleukin 2 (IL-2). This treatment is based on the weak in vivo response of effector T cells to low-dose IL-2 compared with Foxp3+ Treg cells which proliferate due to the expression of the high-affinity IL-2 receptor (CD25). This treatment has been shown to be well tolerated but, since non-specific expansion of the Foxp3+ Treg population cannot be excluded, it may effect susceptibility to infections and malignancies in some patients [51]. Interestingly, it has been shown that the more aggressive and less selective targeting of immune cells leads to more effective disease suppression, though at the cost of enhanced risk of side effects like infections and neoplasms due to decreased normal immune surveillance [27].

Despite the noteworthy advancements in the treatment of MS, the observed rates of progressive disability as well as of early mortality are still bothersome. Accordingly, there exists a need for safer, well tolerated and highly efficient treatments. This need is even higher for therapies capable of stopping or slowing the progression, and improving the disability in progressive MS [14,16,52-54]. Till now, only one therapy (ocrelizumab) appeared to be beneficial for the treatment of PPMS [14,16]. 


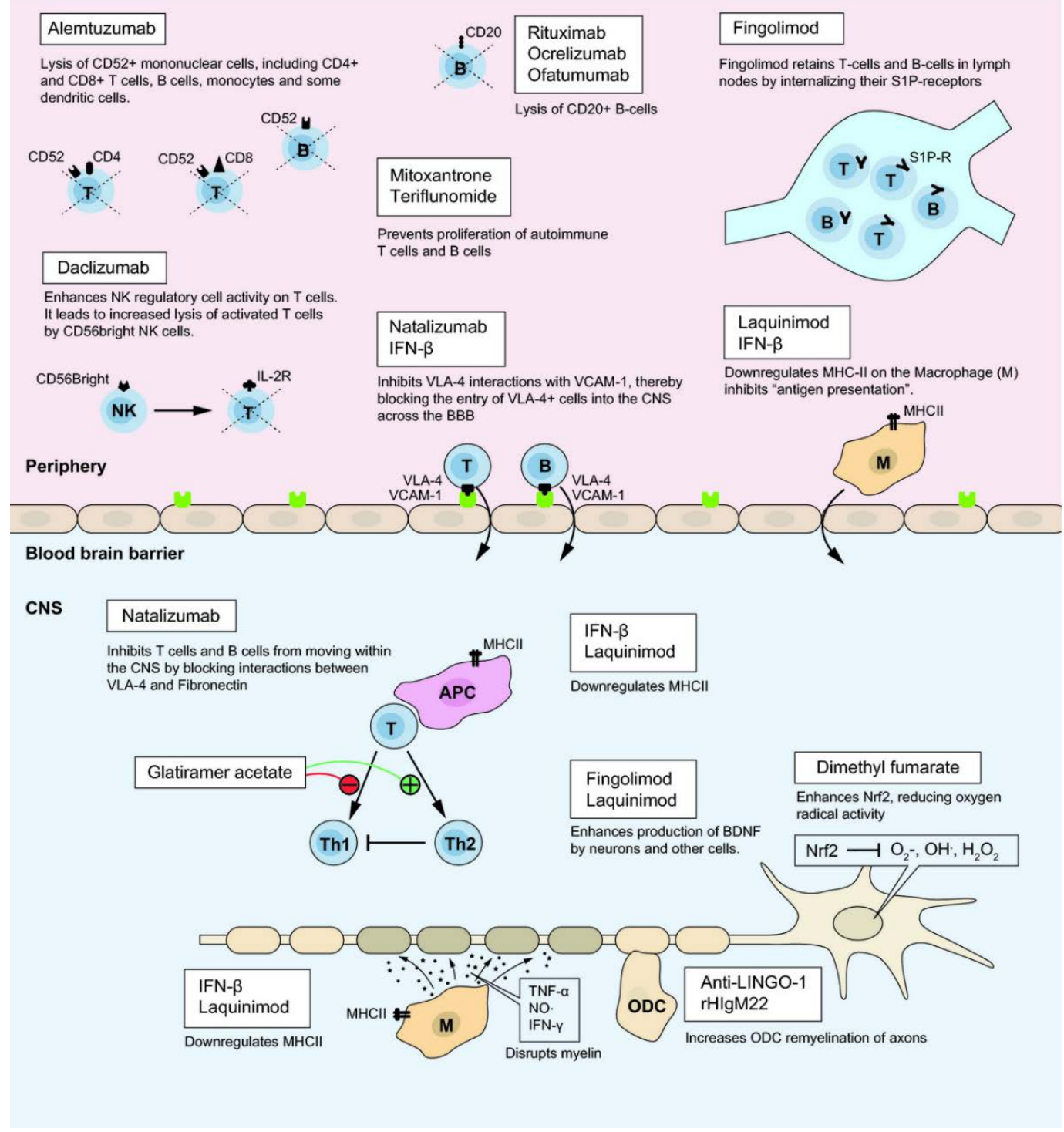

Figure 3. Suggested mechanism of action of several disease-modifying therapies (DMTs) (with the permission of [47]). 
Table 1. Disease-modifying-therapies for RRMS (based on $[16,23,43,45]$ ).

\begin{tabular}{|c|c|c|c|c|c|c|}
\hline Therapeutic Molecule & Commercial Name & Year of Approval & Admin. Route & Admin. Frequency & Mode of Action & Side Effects \\
\hline IFN- $\beta 1 \mathrm{a}$ & $\begin{array}{l}\text { Avonex }^{\circledR} \\
\text { Rebif }^{\circledR}\end{array}$ & 1993 & $\begin{array}{l}\text { i.m. } \\
\text { s.c. }\end{array}$ & $\begin{array}{l}\text { Once a week } \\
\text { Three times a week }\end{array}$ & $\begin{array}{l}\text { Decrease of proinflammatory and increase of } \\
\text { anti-inflammatory cytokines; decreased } \\
\text { migration of inflammatory cells across the BBB; } \\
\text { decrease of Th17 cells; modulation of T and B } \\
\text { cells. }\end{array}$ & $\begin{array}{l}\text { Symptoms similar to those } \\
\text { of flu; leukopenia; liver } \\
\text { damage. }\end{array}$ \\
\hline pegIFN- $\beta 1 \mathrm{a}$ & Plegridy ${ }^{\circledR}$ & & s.c. & Once per two weeks & $\begin{array}{l}\text { Decrease of proinflammatory and increase of } \\
\text { anti-inflammatory cytokines; decreased } \\
\text { migration of inflammatory cells across the BBB; } \\
\text { decrease of Th17 cells; modulation of T and B } \\
\text { cells }\end{array}$ & $\begin{array}{l}\text { Symptoms similar to those } \\
\text { of flu; leukopenia; liver } \\
\text { damage. }\end{array}$ \\
\hline IFN- $\beta 1 \mathrm{~b}$ & $\begin{array}{l}\text { Betaseron }^{\circledR} \\
\text { Extavia }^{\circledR}\end{array}$ & 1993 & s.c. & Once per two days & $\begin{array}{l}\text { Decrease of proinflammatory and increase of } \\
\text { anti-inflammatory cytokines; decreased } \\
\text { migration of inflammatory cells across the BBB; } \\
\text { decrease of Th17 cells; modulation of T and B } \\
\text { cells; down regulation of MHC expression on } \\
\text { APCs. }\end{array}$ & $\begin{array}{l}\text { Symptoms similar to those } \\
\text { of flu; leukopenia; liver } \\
\text { damage. }\end{array}$ \\
\hline Glatiramer acetate & Copaxone $^{\circledR}$ & 1996 & s.c. & - & $\begin{array}{l}\text { Decrease of proinflammatory and increase of } \\
\text { anti-inflammatory cytokines; decrease of Th17 } \\
\text { cells; increase of Th2 cells and Tregs; blocking of } \\
\text { pMHC. }\end{array}$ & $\begin{array}{l}\text { Erythema; induration; heart } \\
\text { palpitations; dyspnea; } \\
\text { tightness of chest; } \\
\text { flushes/anxiety. }\end{array}$ \\
\hline Dimethyl fumarate & Tecfidera $^{\circledR}$ & 2013 & oral & Twice or three times per day & $\begin{array}{l}\text { Anti-inflammatory-Increase of Th2 cells; } \\
\text { anti-oxidative stress; neuroprotection through } \\
\text { activation of Nrf-2 pathway. }\end{array}$ & $\begin{array}{l}\text { Flushes; vomit; diarrhea; } \\
\text { nausea; decrease of WBC. }\end{array}$ \\
\hline Teriflunomide & Aubagio ${ }^{\circledR}$ & 2012 & oral & Once per day & $\begin{array}{l}\text { Inhibition of dihydroorotate dehydrogenase; } \\
\text { inhibition of T and } \mathrm{B} \text { cells; }\end{array}$ & $\begin{array}{l}\text { Lymphopenia; nausea; } \\
\text { hypertension; fatigue; } \\
\text { headache; diarrhea; } \\
\text { peripheral neuropathy; } \\
\text { acute renal failure; alopecia. } \\
\text { Weakening of heart rate; }\end{array}$ \\
\hline Fingolimod & Glenya ${ }^{\circledR}$ & 2010 & oral & Once per day & $\begin{array}{l}\text { S1P receptor modulator; preventing the } \\
\text { circulation of lymphocytes in non-lymphoid } \\
\text { tissues including the CNS. }\end{array}$ & $\begin{array}{l}\text { hypertension; macular } \\
\text { edema; increased liver } \\
\text { enzymes; decreased } \\
\text { lymphocyte levels. }\end{array}$ \\
\hline Siponimod [55] & Mayzent ${ }^{\circledR}$ & 2019 & oral & & Binding to S1P-1 and S1P-5 & \\
\hline Ozanimod [56] & Zeposia $^{\circledR}$ & 2020 USA & oral & & $\begin{array}{l}\text { S1P receptor agonist } \\
\text { Immunomodulation of } \mathrm{T} \text { cells, DCs and }\end{array}$ & \\
\hline Laquinimod & & & Oral & & $\begin{array}{l}\text { monocytes; neuroprotection of astrocytes; } \\
\text { decrease of proinflammatory and increase of } \\
\text { anti-inflammatory cytokines; reduced } \\
\text { infiltration of cells into the CNS. }\end{array}$ & $\begin{array}{l}\text { No severe cardiac adverse } \\
\text { effects were detected during } \\
\text { Phase III clinical trials. }\end{array}$ \\
\hline Cladribine [57] & Mavenclad $^{\circledR}$ & $\begin{array}{l}2017 \text { EU } \\
2019 \text { USA }\end{array}$ & & & Reduction of circulating $\mathrm{T}$ and $\mathrm{B}$ cells. & Risk of cancer \\
\hline
\end{tabular}


Table 1. Cont.

\begin{tabular}{|c|c|c|c|c|c|c|}
\hline Therapeutic Molecule & Commercial Name & Year of Approval & Admin. Route & Admin. Frequency & Mode of Action & Side Effects \\
\hline Mitoxantrone & Novatrone ${ }^{\circledR}$ & 2000 USA & i.v. & Once per three months & $\begin{array}{l}\text { Cytotoxic for B and T cells; reduction of Th1 } \\
\text { cytokines; inhibition of type II topoisomerase. }\end{array}$ & Cardiotoxicity; leukemia \\
\hline Methylprednisolone & & & i.v. & - & Immunosuppression; anti-inflammatory effects. & $\begin{array}{l}\text { Risk of infections; retention } \\
\text { of sodium; glucose } \\
\text { intolerance; mood } \\
\text { disturbances. }\end{array}$ \\
\hline Dalfampridine & Ampyra ${ }^{\circledR}$ & & oral & Twice per day & $\begin{array}{l}\text { Blocking of potassium channel; improvement of } \\
\text { motor symptoms. }\end{array}$ & \\
\hline Natalizumab & Tysabr $^{\circledR}$ & 2004 & i.v. & Once per 28 days & Targeting $\alpha 4$-integrin & $\begin{array}{l}\text { Progressive multifocal } \\
\text { leukoencephalopathy. }\end{array}$ \\
\hline $\begin{array}{l}\text { Ofatumumab } \\
\text { Ocrelizumab }\end{array}$ & $\begin{array}{l}\text { Arzerra }{ }^{\circledR} \\
\text { Ocrevus }^{\circledR}\end{array}$ & & $\begin{array}{l}\text { i.v. } \\
\text { i.v. }\end{array}$ & $\begin{array}{l}\text { Once per two weeks } \\
\text { Once per six months }\end{array}$ & $\begin{array}{l}\text { Targeting CD20 } \\
\text { Targeting CD20 }\end{array}$ & \\
\hline Alemtuzumab & Lemtrada ${ }^{\circledR}$ & $2013 \mathrm{EU}$ & i.v. & Once a year & Targeting CD52 & $\begin{array}{l}\text { High risk of infections } \\
\text { Graves' disease }\end{array}$ \\
\hline Daclizumab & Zinbryta ${ }^{\circledR}$ & & s.c. & Once per month & Targeting CD25 & \\
\hline Rituximab & Rituxan ${ }^{\circledR}$ & & i.v. & - & Targeting CD20 & $\begin{array}{l}\text { Chills; nausea; hypotension } \\
\text { Risk of infections; nausea; }\end{array}$ \\
\hline Obinutuzumab & Gazyva $^{\circledR}$ & & i.v. & - & Direct cell death & $\begin{array}{l}\text { thrombocytopenia; } \\
\text { neutropenia }\end{array}$ \\
\hline
\end{tabular}

IFN: interferon; im : intramuscular; s. : subcutaneous; BBB: blood-brain barrier; MHC: major histocompatibility complex; APCs: antigen presenting cells; Nrf-2: nuclear factor erythroid-2; WBC: white blood cell; CNS: central nervous system; i.v.: intravenous. 


\subsection{Antigen-Specific Immunotherapies}

The Holy Grail for the treatment of MS is to specifically suppress the disease while at the same time allow the immune system to be functionally active against infectious diseases and malignancy. This could be achieved via the development of immunotherapies designed to specifically suppress immune responses to self-antigens [43,51,58-60]. Even though the detailed mechanisms of MS induction have not been fully clarified, a dominant hypothesis is that the loss of immune tolerance to myelin proteins like myelin basic protein (MBP), proteolipid protein (PLP) and myelin oligodendrocyte glycoprotein (MOG) leads to the recruitment of myelin-specific CD4+ T cells, resulting in myelin damage [14,61].

Antigen-specific immunotherapies are based on the introduction of self-antigens to APCs in the absence or presence of very low levels of costimulatory molecules (i) acting directly via TCR on effector $\mathrm{T}$ cells resulting in immunological anergy and deletion of pathogenic $\mathrm{T}$ cell clones (passive tolerance), and (ii) through activation, expansion, and differentiation of antigen-specific regulatory $\mathrm{T}$ cells which secrete anti-inflammatory cytokines (active tolerance) [62,63] (Figure 4).

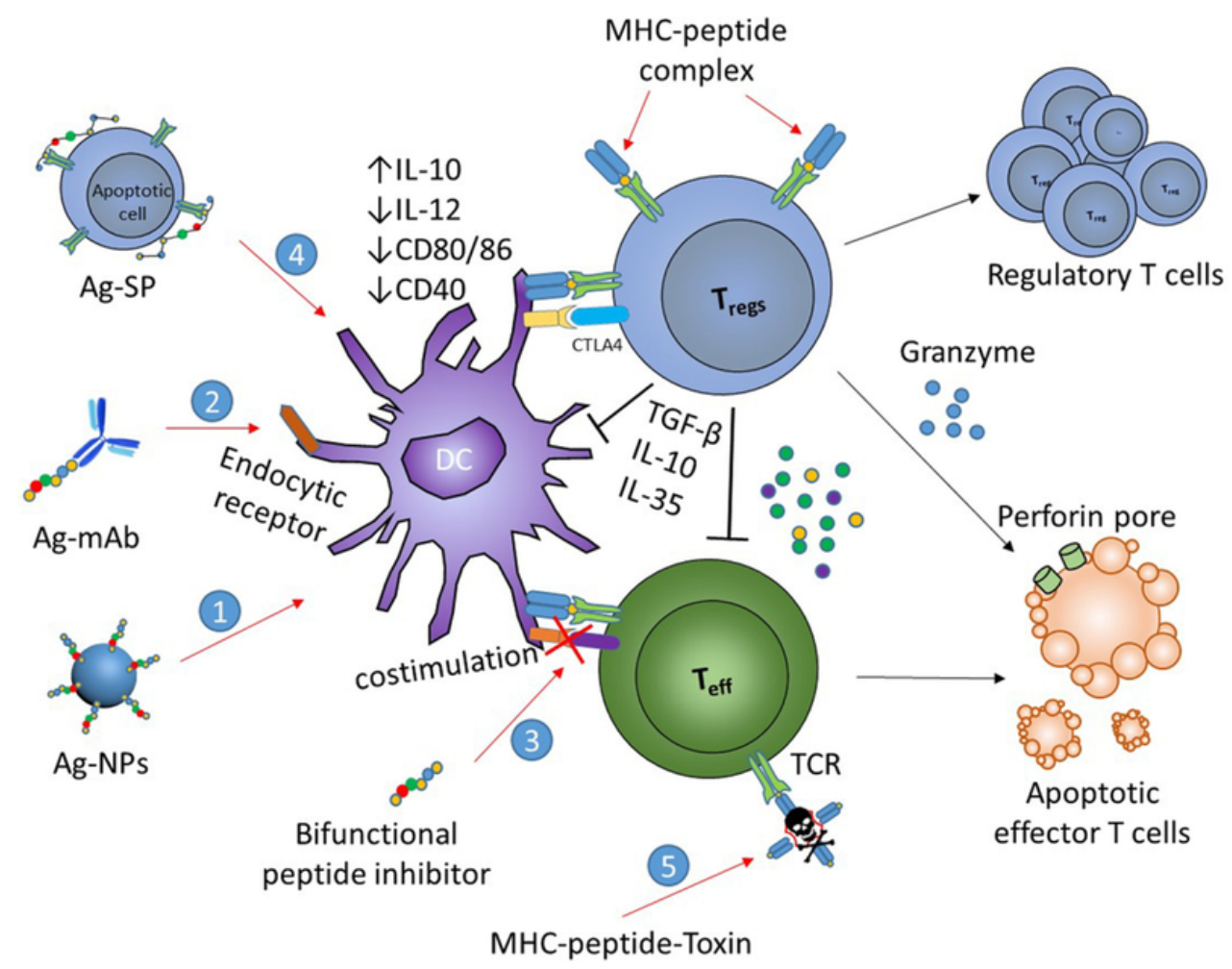

Figure 4. Bioconjugate-based approaches for the induction of Ag-specific tolerance in autoimmune diseases. The engineered bioconjugates target autoantigens and tolerogenic molecules to DCs (1); to facilitate antigen-processing via endocytic receptors (2); to hinder costimulation (3); to link to apoptotic cells for tolerogenic presentation (4); and to deliver toxin to autoantigen-specific T cells (5). These strategic approaches lead to peripheral tolerance as a consequence of anergy and deletion of cognate $\mathrm{T}$ cells, and/or induction of Tregs (with permission of [62]).

More specifically, an immunological synapse is established between APCs and T cells that is based on the formation of a trimolecular complex (signal 1) comprising the HLA class II molecule on the APC, the antigen (e.g., immunodominant epitope of a myelin protein) bound to this molecule and the TCR $[64,65]$. The establishment of the immunological synapse is the most vital process for the activation of effector T cells. In the absence of costimulatory molecules (signal 2), $\mathrm{T}$ cells become unresponsive to the antigen stimulation, a state known as anergy $[65,66]$. The presence of a costimulatory molecule exhibiting inhibitory properties could result to clonal deletion via apoptosis of the $\mathrm{T}$ cells. Autoreactivity of $\mathrm{T}$ lymphocytes can be also suppressed by the induction of regulatory $\mathrm{T}$ 
cells resulting in stable and long-term immune tolerance $[59,65]$. In vivo experiments have revealed that antigen-specific regulatory $\mathrm{T}$ cells are more effective than polyclonal Tregs regarding the control of organ-specific autoimmune diseases [67]. Finally, immune tolerance can be achieved via cytokine induced immune deviation, i.e., skewing of effector T cell subsets from Th1 and Th17 (proinflammatory phenotype) towards Th2 and Tr1 (anti-inflammatory phenotype) [59,65].

Antigen-specific therapies can be categorized according to the nature of the tolerogen (e.g., peptides derived from MBP, PLP, or MOG, mixtures of myelin derived peptides; altered peptide ligands; plasmids encoding myelin derived peptides, peptides related to TCR regions, attenuated myelin-specific T cells, tolerogenic DCs, antigen-coupled cells), the administration route (e.g., intravenous, subcutaneous, intraperitoneal, mucosal, epicutaneous, infusion of Ag-coupled cells) $[14,43,51,59,65]$ and the antigen dose [68]. Since, antigen-specific therapies are thought to combine maximal efficiency with minimal side effects, they could be considered especially appealing [14]. On the other hand, they need to overcome major challenges in order to be efficiently used for the treatment of MS.

The first challenge is that the target antigens in MS are not known and remain to be identified [14,27,65]. The disease is largely heterogeneous. It involves multiple autoantigens (contrary for example to neuromyelitis optica that involves reactivity to Aquaporin-4, AQP4) that can vary between patients depending on genetic characteristics, age, environmental and/or triggering factors, and duration of the disease $[2,27,69,70]$. It has been assumed that myelin targets like MBP, PLP and MOG are relevant, but this is mainly based on EAE models and not on MS patients. Furthermore, therapeutic efficiency in EAE cannot always be translated in MS. Accordingly, the interpretation of the above remains a crucial challenge for the translation of antigen-specific therapies from bench to bedside [27].

Furthermore, it should be noted that the clinical/neuropathological features of MS change noticeably with time [5,70]. Thus, not all patients will necessarily have similar responses to myelin antigen-specific immunotherapies [5]. Additionally, in chronic MS, the pattern of recognized autoantigens progressively increases during the course of the disease, due to a spread of the adaptive immunity to related self-antigens, a phenomenon recognized as epitope spreading [69,70]. Epitope spreading has been defined as the broadening of epitope specificity from the initial immunodominant epitope-specific immune response to other subdominant protein epitopes [71]. Epitope spreading can be categorized as "intra-molecular" related to shifting of immune responses between different epitopes of the same protein (e.g., MBP) and "intermolecular" related to the shifting of immune responses between two proteins (e.g., MBP and PLP) [27,72]. The hierarchy of immunodominant and cryptic epitopes is supposed to be dependent on a combination of peptide processing and presentation by various APCs, and also on the availability of epitope-specific T lymphocytes, taking into account the mechanisms of central and peripheral tolerance [71]. Accordingly, identifying the autoantigens that should be included in the therapeutic formulation can be rather challenging. This problem might be partially overcome via tolerance spreading, i.e., a gradual spread of the tolerance to the administered autoantigens also to other self-antigens which are involved in autoimmunity [70]. Elucidation of the cellular and molecular mechanisms involved in epitope spreading in MS is very important in order to design efficient antigen-specific immunotherapies for MS patients [71]. In this respect, therapeutic strategies targeting a broader array of epitopes may need to be pursued. Furthermore, since immune reactivity broadens with disease duration, antigen-specific immunotherapies should ideally be delivered early in the course of the disease when epitope spreading has not yet occurred, according to an optimized dosage and frequency schedule [14,27,65,73]. An alternative approach could be to achieve bystander suppression (i.e., modulation of the responses to one target antigen leads to modulation of the responses to neighboring target antigens). However, limiting evidence exists for such therapies [27].

Finally, another challenge regarding the translation of antigen-specific immunotherapies from bench to bedside is that the administration of tolerogenic vaccines to MS patients with inapparent infections could be immunogenic and worsen the course of the disease due to its presentation in the 
immune system in a pro-inflammatory environment. This has been the case in clinical trials with APL [74]. Thus, a crucial test for tolerogenic vaccines could be the in vivo assessment of their delivery in a proinflammatory environment, either after EAE onset, or by co-delivery of adjuvants and/or pro-inflammatory stimuli during EAE immunization [63].

Continuing research efforts towards the development of effective and safe antigen-specific therapies for MS gave rise to the epicutaneous administration of antigens (e.g., dermal patch loaded with myelin derived peptides) for the establishment of skin-induced immune tolerance in MS. The ability of skin DCs to induce myelin-specific tolerance has already been demonstrated in both in vivo experiments (Table 2) and early clinical trials [28,58]. Finally, oral tolerance has appeared to be efficient regarding the prevention of EAE, but significantly less efficient concerning the therapy of ongoing EAE and MS [75].

\section{In Vivo Assessment of Tolerance-Inducing Vaccination in MS}

\subsection{Animal Model of MS}

The typically used animal model of MS is that of the experimental autoimmune encephalomyelitis (EAE) [3,4,18,76-80]. EAE is an acute or chronic neuro-inflammatory brain and spinal cord disease [18] which can be induced in various animal strains such as mice, rats, guinea pigs, rabbits, and even primates [7], via immunization with spinal cord homogenate or with various myelin proteins (e.g., MBP, PLP, MOG) emulsified in complete Freund's adjuvant (active EAE) [7,78,81]. EAE can be also transferred to naïve mice via adoptive transfer of T cells specific for myelin [8,78]. In EAE, myelin peptides are presented on MHC class II molecules to autoreactive T cells, together with costimulatory molecules (e.g., CD80 and CD86), resulting in activation of the T lymphocytes and, consequently, in an autoimmune attack on the myelin sheath [79]. EAE is principally mediated by myelin specific CD4+ $T$ cells $[20,78,82,83]$. The clinical course of EAE varies based on the immunized animal species and the encephalitogenic antigen used for the inoculation. Usually the animals experience either an acute monophasic, progressive or not, disease, or a chronic relapsing-remitting disease. Ataxia, weight loss, sagging hind limb and paralysis are among the typical clinical signs of EAE [78]. Interestingly, various effective RRMS therapies (e.g., anti-inflammatory, immunomodulatory therapies) have been developed with the aid of EAE models. However, to date, no EAE model exists, that is capable of reproducing the specific features (e.g., clinical and neuropathological) of progressive MS. Therefore, despite the undeniable value of EAE for basic research concerning the mechanisms of brain inflammation and immune mediated CNS tissue damage, its value as model for MS is limited [18].

\subsection{Myelin Peptide-Based Vaccination}

\subsubsection{Immunodominant Myelin Petides}

Myelin is a multilaminar sheath around nerve fibers comprising lipid bilayers and different proteins. The major myelin proteins are MBP and PLP which represent more than $75 \%$ of the total myelin protein. Additionally, myelin contains MOG [84] representing $~ 0.05 \%$ of the myelin proteins [7], myelin-associated oligodendrocyte basic protein (MOBP), oligodendrocyte-specific protein (OSP), myelin-associated glycoprotein (MAG), and Nogo-A [85].

While the etiology of MS is not clear yet, a favored hypothesis supported by experimental evidence indicates that the cross-reactive immune response between myelin derived epitopic peptides and viral or bacterial components can be considered as an important factor that contributes to the development of autoimmune $\mathrm{T}$ cells which initiate a demyelinating inflammatory response. Thus, the determination of the main epitopes of the encephalitogenic myelin and/or neuronal proteins that are implicated in MS is considered of major significance both for the development of antigen-specific therapies for MS and the elucidation of MS pathophysiology and etiology [85]. 
In recent decades, extensive studies have been performed aiming to identify the immunodominant epitopes recognized by $\mathrm{T}$ lymphocytes in MS. These studies have revealed that only the myelin proteins MBP, PLP, MOG, MOBP, and OSP can induce clinical EAE in laboratory animals and that autoimmune $\mathrm{T}$ cells against these proteins can be detected in MS patients. Other myelin proteins, like MAG and Nogo-A have been also identified as encephalitogenic proteins. Finally, some neuronal components (e.g., $\beta$-Synuclein, Neurofilament) have been found to exhibit encephalitogenic potential [85]. Antigen recognition takes place in the setting of a trimolecular complex formed by HLA, myelin peptide and TCR $[64,86,87]$. The immunodominant PLP epitopes which can be processed by human APCs lie within the PLP regions 30-60 and 180-230. Similarly, the PLP epitopes that activate T lymphocytes in EAE are within the 40-70, 90-120 and 180-230 regions of the protein [5]. Immunodominant epitopes of MOG that are recognized by encephalitogenic T cells in MS as foreign antigens are $\mathrm{MOG}_{1-22}, \mathrm{MOG}_{35-55}$ and MOG $_{92-106}$ with the 35-55 epitope being the major immunodominant region of MOG [86]. Analysis of $\mathrm{T}$-cell responses to $\mathrm{MOBP}$ in SJL/J mice indicated $\mathrm{MOBP}_{15-36}$ as the main encephalitogenic epitope of MOBP [85].

A cyclic analogue of $\mathrm{MBP}_{87-99}$ has been designed by Matsoukas and coworkers taking into consideration HLA (His ${ }^{88}$, $\mathrm{Phe}^{90}$, $\mathrm{Ile}^{93}$ ) and T-cell $\left(\mathrm{Phe}^{89}{\text {, } \mathrm{Lys}^{91} \text {, Pro }}^{96}\right.$ ) contact side-chain information. cyclo(87-99)MBP 87-99 was shown to induce EAE, bind HLA-DR4, and enhance CD4+ T-cell proliferation, similarly to the linear $\mathrm{MBP}_{87-99}$ peptide [83]. Additionally, peptide analogues derived from the encephalitogenic peptide $\mathrm{MBP}_{82-98}$, the altered peptide ligand $\mathrm{MBP}_{82-98}$ (Ala ${ }^{91}$ ) and their cyclic analogues were synthesized by Deraos and coworkers and assessed regarding their binding to HLA-DR2 and HLA-DR4 alleles involved in the presentation of myelin epitopes to T cells. The cyclic $\mathrm{MBP}_{82-98}$ was shown to bind strongly to HLA-DR2 and to have a lower affinity to the HLA-DR4 allele. Both the cyclic and APL analogues of $\mathrm{MBP}_{82-98}$ were found to be promising and were selected to be further evaluated regarding their ability to modulate the responses of autoreactive T cells in MS [88]. In addition to the abovementioned studies, Tapeinou and coworkers developed a peptide compound comprising the $\mathrm{MBP}_{85-99}$ immunodominant epitope coupled to an anthraquinone derivative (AQ) via a disulfide (S-S) and six amino hexanoic acid (Ahx) residues. AQ-S-S-(Ahx)6MBP $85-99$ was found to bind reasonably to HLA II DRB1*-1501 antigen indicating the possibility of eliminating encephalitogenic T lymphocytes through generation of a toxic, thiol-containing moiety (AQ-SH) [89].

Yannakakis and coworkers used molecular dynamic simulations to study the interactions of the MOG epitope $\mathrm{MOG}_{35-55}$ with the HLA and TCR receptors during the formation of the trimolecular complex TCR-hMOG $35-55$-HLA DR2 [64]. They also used robust computational methods (e.g., molecular dynamics, pharmacophore modeling, molecular docking) to rationally design non-peptide mimetic molecules capable of binding with enhanced affinity to the T-cell receptor and not to the MHC-peptide complex, thus impeding the formation of the trimolecular complex [90].

To date various studies have assessed different myelin epitopes, as single peptides or mixtures of them, regarding their ability to induce antigen-specific tolerance in EAE animal models (Table 2).

\subsubsection{Altered Peptide Ligands (APLs)}

Altered peptide analogues (APLs) of the immunodominant myelin protein epitopes have been successfully synthesized and applied in antigen-specific immunotherapies in vivo (Table 2). They are molecules where one or more amino acids in the sequence of the native immunodominant peptides, crucial for the interaction with the TCR, have been substituted. Depending on the substitutions, APLs can induce protective or therapeutic immune responses against EAE [91]. APLs can change agonist peptides into antagonist ones. Antagonistic peptides participating in the trimolecular complex MHC-peptide-TCR and causing suppression of EAE exhibit loss of their side chain interactions with the complementarity determining region 3 (CDR3) loop of the TCR. Substitution of large side chains interacting with the TCR with small side chain amino acids (e.g., Ala) causes antagonism and, therefore, inhibition of EAE symptoms. Moreover, APLs can switch Th1 cell response towards Th2 thus leading to disease suppression. Finally, APLs might activate regulatory T cells capable of antagonizing the 
deleterious actions of encephalitogenic cells in the CNS [83,87]. Accordingly, mutant cyclic peptides of MBP87-99 (e.g., cyclo(91-99)[Ala96]MBP87-99 and cyclo(87-99)[Arg91Ala96]MBP87-99) were shown to suppress the proliferation of a CD4 T-cell line from a MS patient, bind to HLA-DR4 and exhibit an increased Th2/Th1 cytokine ratio in peripheral BMCs derived from MS patients [83].

Molecular dynamics were applied by Mantzourani and coworkers to study the interactions of

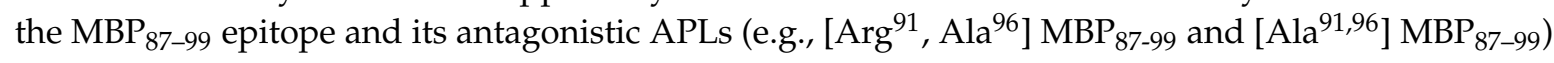
with the receptor HLA-DR2b [92].

\subsubsection{Y-MSPc}

Kaushansky and coworkers [93,94] pursued a "multi-epitope-targeting" approach aiming to simultaneously neutralize $\mathrm{T}$ lymphocytes reactive against various major encephalitogenic epitopes. In this respect, they designed a recombinant synthetic protein comprising multiple epitopes of the human myelin protein (Y-MSPc). Y-MSPc was shown to efficiently inhibit the development of EAE induced in mice by a single epitope of myelin protein (classical EAE) or by a cocktail of five different encephalitogenic peptides (complex EAE) and suppress its progression, outperforming the single disease-specific epitope and the.mixture of peptides (Table 2).

\subsubsection{Cytokine-Neuroantigen (NAg) Fusion Proteins}

Fusion proteins consisting of a cytokine (N-terminal domain) fused with or without an appropriate linker to a neuroantigen (C-terminal domain) represent an emerging platform for antigen-specific vaccination $[95,96]$. Regarding their mechanism of action, the cytokine domain of the vaccine exhibits high affinity binding to specific surface cytokine receptors on certain subsets of APCs. This results in highly efficient uptake of the neuroantigen domain by these APCs, and its processing and presentation on MHC class II molecules to NAg-specific T lymphocytes. NAg tolerogenic presentation is assumed to induce regulatory responses and results in the establishment of antigen-specific immunological tolerance (Figure 5) [96,97].

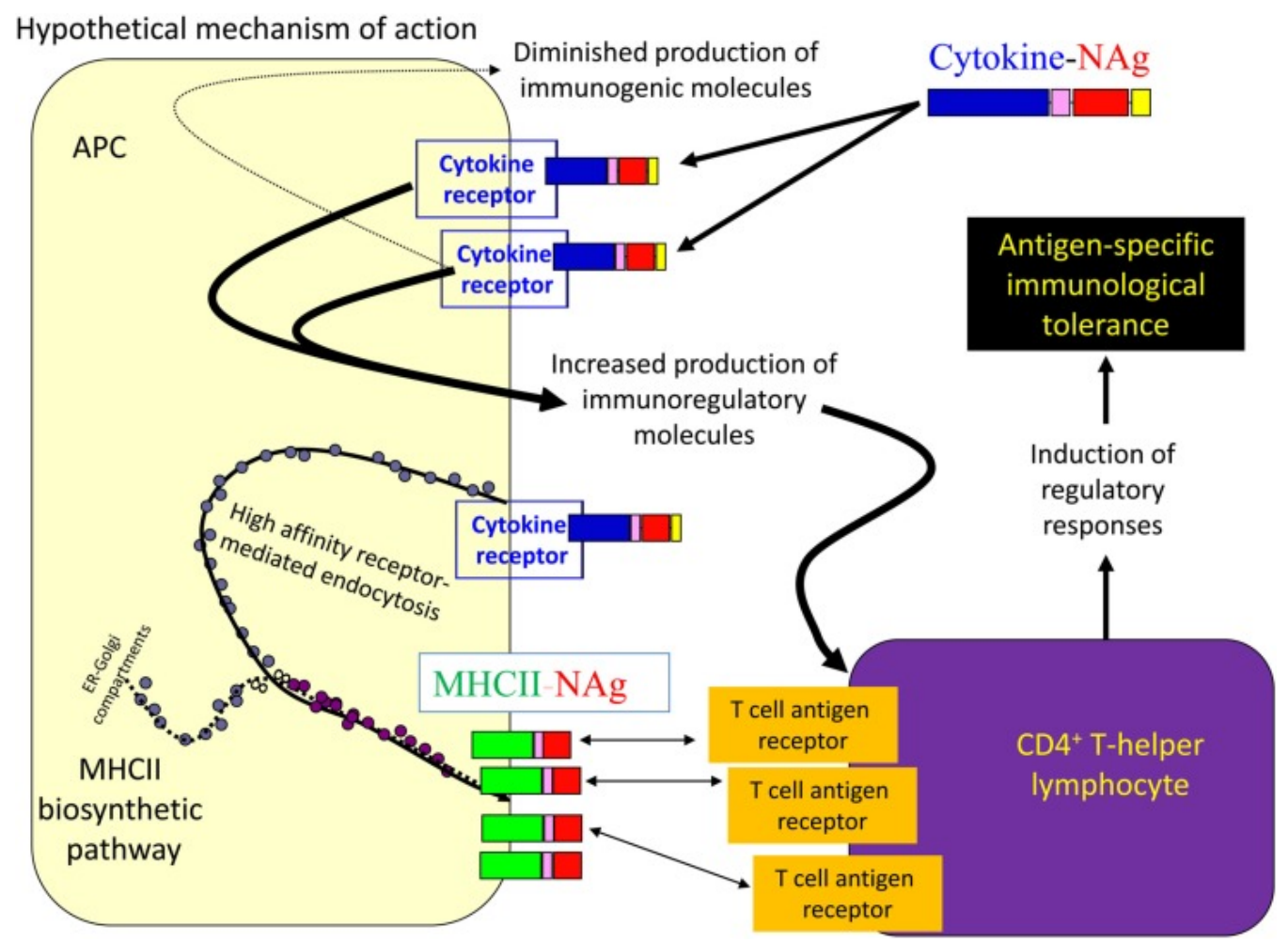

Figure 5. Mechanism of action of cytokine-NAg fusion proteins [96]. 
Various single-chain cytokine-neuroantigen (NAg) fusion proteins (e.g., granulocyte-macrophage colony-stimulating factor (GMCSF)-NAg, IFN $\beta-N A g$, IL16-NAg, IL2-NAg), where NAg comprises self-myelin epitopes, have been examined as potential tolerogenic and/or therapeutic antigen-specific vaccines in EAE mouse models (Table 2). The developed fusion proteins have been found to target APCs and to effectively prevent the induction of EAE when administered prophylactically as well as to suppress pre-developed EAE. Due to their combined preventive and therapeutic activities, the cytokine-NAg vaccines were characterized as both tolerogenic and therapeutic.The ranking order with respect to their inhibitory activity was the following: GMCSF-NAg, IFN $\beta$-NAg > NAgIL16 > IL2-NAg > MCSF-NAg, IL4-NAg, IL-13-NAg, IL1RA-NAg. [96].

Apart from the aforementioned cytokine-NAg fusion proteins, the macrophage colony stimulating factor (MCSF)-NAg fusion protein was used in order to increase the presentation of NAg by macrophages. However, it was found to be less tolerogenic than GMCSF-Nag, thus indicating the latter fusion protein as the most suitable for antigen-specific vaccination [95,98]. Additionally, it was revealed that GMCSF-MOG does not require a non-inflammatory quiescent environment to effectively prevent the development of EAE which contradicts the previous knowledge regarding tolerogenic vaccines $[95,98]$.

\subsubsection{Antibodies Coupled with Myelin Peptides}

The dendritic and epithelial cell receptor with molecular weight equal to $205 \mathrm{kDa}$ (DEC205) is expressed by DCs and enables antigen presentation. Injection of antigens (Ags) coupled to antibodies (Abs) specific for DEC205 into mice, at a low dose (e.g., $\leq 0.1 \mu \mathrm{g}$ of fusion $\mathrm{mAb}$ [99]) leads to $\mathrm{Ag}$ presentation by nonactivated DCs, resulting in induction of regulatory T lymphocytes. In this respect, fusion of $\alpha$ DEC-205 Abs with MOG $_{35-55}$ [100] and PLP ${ }_{139-151}$ [101] ameliorated EAE in mice. Similarly, Ring and coworkers synthesized single chain fragment variables (scFv) specific for DEC205. scFvs were subsequently fused with MOG (scFvDEC:MOG) and administered to mice both before and after induction of EAE. Significant prevention of EAE was observed by vaccination with scFv DEC:MOG before immunization. In addition, administration of scFv DEC:MOG post immunization led to substantial alleviation of the clinical symptoms of the disease [102]. On the other hand, Tabansky and coworkers targeted the dendritic cell inhibitory receptor 2 (DCIR2) receptor with $\alpha \mathrm{DCIR} 2$ Abs fused to PLP ${ }_{139-151}$ and observed significant alleviation of EAE clinical symptoms [79]. In another approach, Kasagy and co-workers demonstrated that administration of anti-CD4 and anti-CD8 Abs followed by injection of $\mathrm{PLP}_{139-151}$ resulted in substantially lower EAE scores and reduced rate of relapses in chronic disease in mice [103] (Table 2).

\subsubsection{Recombinant T-cell Receptor Ligands (RTLs)}

Antigen-specific immunosuppression can be induced via the utilization of MHC-peptide complexes as specific TCR ligands interacting with autoimmune T cells in the absence of co-stimulatory molecules. A recombinant TCR ligand (RTL) typically comprises a single polypeptide chain encoding the $\beta 1$ and $\alpha 1$ domains of MHC class II molecules linked to a self-antigen [104] and represents the minimal interactive surface with antigen-specific TCR. RTLs fold in a similar manner to native four-domain MHC/peptide complexes but they deliver qualitatively different, suboptimal signals which cause a "cytokine change" to anti-inflammatory factors in targeted autoreactive T cells. Treatment with RTLs could reverse the clinical/histological signs of EAE in different experimental cases (e.g., MBP-induced monophasic disease, MOG peptide-induced chronic EAE, PLP-induced relapsing remitting EAE) and even promote recovery of myelin and axons in mice with chronic disease [105-107] (Table 2).

Alternatively, RTLs could involve natural or recombinant $\alpha_{1} \alpha_{2}$ and $\beta_{1} \beta_{2}$ MHC class II domains covalently or noncovalently linked with encephalitogenic or other pathogenic peptides. These specific RTLs could bind both to the TCR and the CD4 molecule on the T cells surface via the $\beta_{2}$ MHC domain and were shown to hinder the activation of $\mathrm{T}$ cell and thus prevent EAE in rodents [108]. 
Table 2. Myelin protein/peptide-based vaccination.

\begin{tabular}{|c|c|c|c|c|c|c|c|}
\hline Vaccine & Antigen & Targeting Ligand/Drug & Vaccination Type & Admin. Route & Admin. Dose & Animal Model & Vaccination Outcome \\
\hline \multicolumn{8}{|l|}{ Myelin Proteins/Peptides } \\
\hline MBP [112] & Guinea pig MBP & - & $\begin{array}{l}\text { Prophylactic: seven days } \\
\text { b.i. }\end{array}$ & e.c. & & $\begin{array}{l}\text { SJLxB10.PL female mice (6-8 } \\
\text { weeks old) with EAE } \\
\text { induced with MBP }\end{array}$ & $\begin{array}{l}\text { Protection from RR form of EAE } \\
\text { Reduction of disease incidence to } \\
58 \%\end{array}$ \\
\hline MBP [113] & Guinea pig MBP & - & $\begin{array}{l}\text { Prophylactic: seven and } \\
\text { three days bi. } \\
\text { Therapeutic: at initial signs } \\
\text { of EAE and after four days }\end{array}$ & e.c. & & $\begin{array}{l}\text { B10.PL female mice (6-8 } \\
\text { weeks old) with EAE } \\
\text { induced with MBP }\end{array}$ & $\begin{array}{l}\text { Prophylactic vaccine: protection } \\
\text { from EAE Therapeutic vaccine: } \\
\text { suppression of EAE }\end{array}$ \\
\hline MBP [114] & Guinea pig MBP & - & $\begin{array}{l}\text { Prophylactic: seven and } \\
\text { three days b.i. }\end{array}$ & e.c. & & $\begin{array}{l}\text { B10.PL and SJLxB10.PL } \\
\text { female mice (6-8 weeks old) } \\
\text { with acute or RR EAE } \\
\text { respectively, induced with } \\
\text { MBP } \\
\text { Knock out mice: TCR } \delta-- \text {, } \\
\text { CD1d- }-- \text { and } \beta_{2} \mathrm{~m}-/- \text { on } \\
\text { H-2 } 2^{\mathrm{u}} \text { background. }\end{array}$ & $\begin{array}{l}\text { Vaccination with MBP prior to } \\
\text { EAE induction prevented the } \\
\text { development of the disease } \\
\text { (incidence reduction by } 50 \% \text { ) and } \\
\text { reduced the severity of the } \\
\text { clinical symptoms in the mice } \\
\text { that developed EAE. } \\
\text { Experiments with knock out } \\
\text { mice showed that the disease } \\
\text { could not be completely } \\
\text { suppressed only in } \beta_{2} \mathrm{~m}-/- \text { mice. }\end{array}$ \\
\hline $\mathrm{MOG}_{35-55}[115]$ & $\mathrm{MOG}_{33-55}$ & - & $\begin{array}{l}\text { Preclinical/Therapeutic: } 3 \text {, } \\
\text { 5, and } 7 \text { days p.i. }\end{array}$ & i.v. & & $\begin{array}{l}\text { C57BL/ } 6 \text { female mice ( } 8-10 \\
\text { weeks old) with EAE } \\
\text { induced with } \text { MOG }_{35-55}\end{array}$ & $\begin{array}{l}\text { Dramatic suppression of EAE } \\
\text { development }\end{array}$ \\
\hline $\mathrm{c}-\mathrm{MOG}_{35-55}[116]$ & $\begin{array}{l}\mathrm{MOG}_{35-55} \text { and } \\
\text { cyclic- } \text { MOG }_{35-55}\end{array}$ & - & $\begin{array}{l}\text { Preclinical/Therapeutic on } \\
\text { the same day with } \\
\text { immunization and seven } \\
\text { days p.i. }\end{array}$ & s.c. & & $\begin{array}{l}\text { C57BL/ } / 6 \text { female mice (6-10 } \\
\text { weeks old) with EAE } \\
\text { induced with } \mathrm{MOG}_{35-55}\end{array}$ & $\begin{array}{l}\text { Amelioration of EAE clinical } \\
\text { course and pathology. Reduction } \\
\text { of clinical severity of acute phase } \\
\text { of EAE and reduction of overall } \\
\text { EAE burden. }\end{array}$ \\
\hline ATX-MS-1467 [117] & $\begin{array}{l}\text { Mixture of } \mathrm{MBP}_{30-44} \\
\text { MBP }_{131-145,} \\
\text { MBP }_{140-154,} \\
\text { MBP }_{83-99}\end{array}$ & - & $\begin{array}{l}\text { Prophylactic } \\
\text { Preclinical/Therapeutic }\end{array}$ & s.c. & $\begin{array}{l}100 \mu \mathrm{L} \text { of ATX-MS-1467 } \\
\text { twice a week }\end{array}$ & $\begin{array}{l}\text { (ObxDR2)F1 mice with EAE } \\
\text { induced with spinal cord } \\
\text { homogenate }\end{array}$ & $\begin{array}{l}\text { ATX-MS- } 1467 \text { was shown to } \\
\text { effectively prevent and treat EAE } \\
\text { The inhibition of the disease was } \\
\text { found to be dose-dependent. }\end{array}$ \\
\hline Pool of MBP peptides [118] & $\begin{array}{l}\mathrm{MBP}_{68-86} \text { and } \\
\mathrm{MBP}_{87-99}\end{array}$ & & $\begin{array}{l}\text { Therapeutic: secen and } 11 \\
\text { days p.i. }\end{array}$ & i.n. & $\begin{array}{l}500 \mu \mathrm{g} \text { of each MBP } \\
\text { peptide/rat }\end{array}$ & $\begin{array}{l}\text { Lewis female rats }(9 \text { weeks } \\
\text { old) with EAE induced with } \\
\text { MBP }_{68-86}\end{array}$ & $\begin{array}{l}\text { Tolerization to a pool of MBP } \\
\text { peptides was found to result in } \\
\text { amelioration of clinical } \\
\text { symptoms of EAE. }\end{array}$ \\
\hline $\mathrm{MOG}_{35-55}[119]$ & $\mathrm{MOG}_{35-55}$ & - & $\begin{array}{l}\text { Prophylactic: every other } \\
\text { day, for } 10 \text { days b.i. }\end{array}$ & oral & $200 \mu \mathrm{g}$ of $\mathrm{MOG}_{35-55}$ & $\begin{array}{l}\text { C57BL/6 male mice (6-8 } \\
\text { weeks old) with EAE } \\
\text { induced with } \text { MOG }_{35-55} \text {. }\end{array}$ & $\begin{array}{l}\text { Oral vaccination with } \mathrm{MOG}_{35-55} \\
\text { was found capable of efficiently } \\
\text { suppressing pathogenic cells. } \\
\text { Euthymic Tg mice were shown to }\end{array}$ \\
\hline MBP [120] & MBP & - & Prophylactic: one day b.i. & oral & $100 \mathrm{mg}$ of MBP & $\begin{array}{l}\text { Euthymic and adult } \\
\text { thymectomized Tg mice } \\
\text { with EAE induced with } \\
\text { MBP. }\end{array}$ & $\begin{array}{l}\text { be protected from EAE after oral } \\
\text { administration of MBP contrary } \\
\text { to thymectomized mice, thus } \\
\text { indicating the key role of thymus } \\
\text { in oral tolerance induction. }\end{array}$ \\
\hline
\end{tabular}


Table 2. Cont.

\begin{tabular}{|c|c|c|c|c|c|c|c|}
\hline Vaccine & Antigen & Targeting Ligand/Drug & Vaccination Type & Admin. Route & Admin. Dose & Animal Model & Vaccination Outcome \\
\hline \multicolumn{8}{|c|}{ Altered peptide ligands (APLs) } \\
\hline APL [121] & 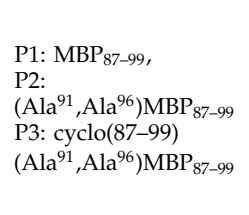 & - & $\begin{array}{l}\text { Prophylactic: on the day of } \\
\text { immunization }\end{array}$ & s.c. & & $\begin{array}{l}\text { Female Lewis rats (6-8 } \\
\text { weeks old) with EAE } \\
\text { induced with } \mathrm{MBP}_{74-85}\end{array}$ & $\begin{array}{l}\text { Suppression of EAE was } \\
\text { detected } 8 \text { days post P2 and P3 } \\
\text { administration. P1 was not } \\
\text { found to suppress EAE. P2 was } \\
\text { shown to suppress EAE between } \\
8-16 \text { days whereas P3 suppressed } \\
\text { EAE until the end of the } \\
\text { experiment (e.g., day } 18 \text { or 20). }\end{array}$ \\
\hline APL [87] & 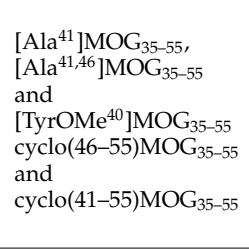 & - & $\begin{array}{l}\text { Prophylactic: on the day of } \\
\text { immunization. }\end{array}$ & s.c. & & $\begin{array}{l}\text { C57BL } / 6 \text { female mice }(12-18 \\
\text { weeks old) with EAE } \\
\text { induced with rat } \mathrm{MOG}_{35-55}\end{array}$ & 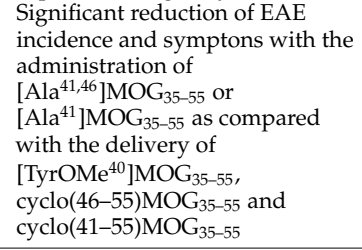 \\
\hline \multicolumn{8}{|l|}{ Y-MSPc } \\
\hline Y-MSPc [94] & $\begin{array}{l}\text { MOG }_{34-56} \\
\text { MBP }_{89-104} \\
\text { OSP }_{55-80} \\
\text { OSP }_{179-201} \\
\text { MOBP }_{15-36} \\
\text { PLP }_{139-151} \\
\text { PLP }_{178-191}\end{array}$ & - & $\begin{array}{l}\text { Preclinical/Therapeutic: } 3 \text {, } \\
5,7 \text {, and } 21 \text { days p.i. }\end{array}$ & i.v. & $75 \mu \mathrm{g}$ of $\mathrm{Y}-\mathrm{MSP} \mathrm{c} /$ mouse & $\begin{array}{l}\text { SJL/J female mice (2-3 } \\
\text { months old) with EAE } \\
\text { induced with PLP } 139-151\end{array}$ & $\begin{array}{l}\text { Y-MSPc was revealed to be more } \\
\text { efficient in inhibiting the } \\
\text { development of the disease and } \\
\text { suppressing its progression in } \\
\text { comparison with a single } \\
\text { encephalitogenic peptide or a } \\
\text { cocktail of peptides. }\end{array}$ \\
\hline Y-MSPc [93] & $\begin{array}{l}\text { OSP }_{55-74} \\
\text { MOBP }_{55-77} \\
\text { MOBP }_{15-36} \\
\text { MOG }_{34-56} \\
\text { PLP }_{175-194} \\
\text { PLP }_{139-151} \\
\text { MBP }_{89-104}\end{array}$ & & $\begin{array}{l}\text { Preclinical/Therapeutic: } \\
\text { administration post } \\
\text { immunization }\end{array}$ & i.v. & $75 \mu \mathrm{g}$ of Y-MSPc/mouse & 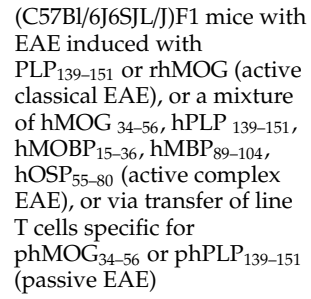 & $\begin{array}{l}\text { Y-MSPc was shown to be more } \\
\text { efficient in inhibiting the } \\
\text { development of classical or } \\
\text { complex EAE, suppressing the } \\
\text { disease course and reversing the } \\
\text { chronic disease, compared with a } \\
\text { single encephalitogenic peptide } \\
\text { or a cocktail of peptides. } \\
\text { Additionally, Y-MSPc appeared } \\
\text { to be more effective in } \\
\text { suppressing passive EAE. }\end{array}$ \\
\hline
\end{tabular}


Table 2. Cont.

\begin{tabular}{|c|c|c|c|c|c|c|c|}
\hline Vaccine & Antigen & Targeting Ligand/Drug & Vaccination Type & Admin. Route & Admin. Dose & Animal Model & Vaccination Outcome \\
\hline \multicolumn{8}{|c|}{ Cytokine-neuroantigen (NAg) fusion proteins } \\
\hline $\begin{array}{l}\text { GMCSF-NAg and } \\
\text { MCSF-NAg [60] }\end{array}$ & $\begin{array}{l}\text { Guinea pig } \\
\text { MBP }_{69-87}\end{array}$ & $\begin{array}{l}\text { GM-CSF M-CSF } \\
\text { cytokines }\end{array}$ & $\begin{array}{l}\text { Therapeutic: Exp.1: } 9,10, \\
\text { 12, and } 14 \text { days p.i.; exp. } 2: \\
10,11 \text { and } 13 \text { days p.i.; exp. } \\
\text { 3: eight and } 11 \text { days p.i. }\end{array}$ & s.c. & $\begin{array}{l}1 \mathrm{nmol} \text { of fusion } \\
\text { protein(s) per injection } \\
\text { (exp. } 1 \text { and } 2) \text {, } \\
4 \text { nmol on day } 8 \text { and } 1 \\
\text { nmol on day } 11 \text { (exp. } 3 \text { ) }\end{array}$ & $\begin{array}{l}\text { Lewis rats with EAE } \\
\text { induced with DHFR-NAg } \\
\text { fusion protein }\end{array}$ & $\begin{array}{l}\text { GMCSF-NAg was found to } \\
\text { potently target MBP } \mathrm{P}_{69-87} \text { to } \\
\text { subsets of myeloid APCs and to } \\
\text { successfully induce } \\
\text { antigen-specific tolerance. }\end{array}$ \\
\hline $\begin{array}{l}\text { GMCSF-NAg MCSF-NAg } \\
\text { [98] }\end{array}$ & $\mathrm{MBP}_{69-87}$ & $\begin{array}{l}\text { GMC-SF } \\
\text { MCSF }\end{array}$ & $\begin{array}{l}\text { Prophylactic: } 21,1,4 \text { and } 7 \\
\text { days b.i. } \\
\text { Therapeutic: } 9,10,12 \text { and } \\
\text { 14 days p.i. (exp. 1), or } 10, \\
11 \text {, and 13 days p.i. (exp. 2), } \\
\text { or eight and 11 days p.i. } \\
\text { (exp. 3) }\end{array}$ & s.c. & $\begin{array}{l}\text { Prophylactic: } 4 \text { nmol of } \\
\text { fusion protein(s) per } \\
\text { injection } \\
\text { Therapeutic: } 1 \mathrm{nmol} \\
\text { (exp. } 1 \& 2), 4 \mathrm{nmol} \text { on } \\
\text { day } 8 \text { and } 1 \mathrm{nmol} \text { on } \\
\text { day } 11 \text { (exp. 3) }\end{array}$ & $\begin{array}{l}\text { Lewis rats with EAE } \\
\text { induced with DHFR-NAg } \\
\text { fusion protein }\end{array}$ & $\begin{array}{l}\text { Prophylactic vaccination with } \\
\text { GMCS-NAg resulted in } \\
\text { attenuation of EAE severity. } \\
\text { Furthermore, treatment with } \\
\text { GMCSF-NAg successfully } \\
\text { inhibited EAE progression to } \\
\text { more severe stages. }\end{array}$ \\
\hline GMCSF-NAg [122] & $\mathrm{MOG}_{35-55}$ & GM-CSF & Preclinical/Therapeutic: p.i. & s.c. & $\begin{array}{l}2 \text { or } 1 \mathrm{nmol} \text { of } \\
\text { GMCSF-NAg }\end{array}$ & $\begin{array}{l}\text { C57BL/6 mice with EAE } \\
\text { induced with MOG } 35-55 \\
\text { (active EAE) or with } \\
\text { activated MOG-specific Th1 } \\
\text { T cells (passive EAE). SJL } \\
\text { mice with EAE induced } \\
\text { with PLP E139-151- B cell } \\
\text { deficient, CD4-deficient, } \\
\text { IFN- } \gamma \text { R1-deficient, and 2D2 }\end{array}$ & $\begin{array}{l}\text { GMCSF-NAg was shown to } \\
\text { suppress the established disease } \\
\text { especially in passive EAE models. } \\
\text { It also proved to be an efficient } \\
\text { therapy for Cd4-defficient mice } \\
\text { and to exhibit tolerogenic activity } \\
\text { in B cell deficient mice. }\end{array}$ \\
\hline Cytokine-NAg [97] & $\begin{array}{l}\text { MOG }_{35-55} \\
\text { PLP }_{139-151}\end{array}$ & GM-CSF & $\begin{array}{l}\text { Prophylactic: } 21,14 \text { and } 7 \\
\text { days b.i. } \\
\text { Therapeutic: } 13,15,17 \text {, and } \\
20 \text { days p.i. }\end{array}$ & s.c. & $\begin{array}{l}\text { Prophylactic: } 2 \mathrm{nmol} \text { of } \\
\text { cytokine-NAg } \\
\text { Therapeutic: } 4 \mathrm{nmol} \text { on } \\
\text { days } 9 \text { and } 11 \text {, and } 2 \\
\text { nmol on day } 14 \text { p.i. }\end{array}$ & 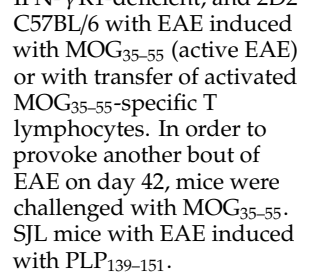 & $\begin{array}{l}\text { Fusion of GM-CSF with myelin } \\
\text { protein epitopes was found to } \\
\text { lead to efficient antigen uptake } \\
\text { by myeloid APCs resulting in } \\
\text { blocking of the development and } \\
\text { progression of EAE. }\end{array}$ \\
\hline Cytokine-NAg [96] & $\begin{array}{l}\mathrm{MBP}_{69-87} \\
\mathrm{MBP}_{73-87} \\
\mathrm{PLP}_{139-151} \\
\mathrm{MOG}_{35-55}\end{array}$ & $\begin{array}{l}\text { GMCSF } \\
\text { IFN- } \beta \\
\text { IL16 } \\
\text { IL2 }\end{array}$ & $\begin{array}{l}\text { Prophylactic: } 21,14 \text {, and } 7 \\
\text { days b.i. } \\
\text { Therapeutic: } 13,15,17 \text {, and } \\
20 \text { days p.i. or alternatively } \\
\text { after the onset of paralysis }\end{array}$ & s.c. & & $\begin{array}{l}\text { C57BL/ } 6 \text { mice with EAE } \\
\text { induced with MOG } 35-55 . \text { SJL } \\
\text { mice with RR EAE induced } \\
\text { with PLP } 139-151 \text {. Lewis rats } \\
\text { with EAE (acute } \\
\text { monophasic form) induced } \\
\text { with MBP } 73-87\end{array}$ & $\begin{array}{l}\text { The developed cytokine-NAg } \\
\text { fusion proteins were shown to } \\
\text { target APCs and to successfully } \\
\text { prevent the induction of EAE } \\
\text { when administered } \\
\text { prophylactically as well as to } \\
\text { suppress on-going EAE. }\end{array}$ \\
\hline Cytokine-NAg [123] & Guinea pig MBP & rat IL-2 or IL-4 & $\begin{array}{l}\text { Prophylactic: } 21,14 \text { and } 7 \\
\text { days b.i. } \\
\text { Preclinical/Therapeutic: } \\
\text { five days p.i. and on every } \\
\text { other day through days } 9 \text {, } \\
11 \text {, or } 13 \text { p.i. }\end{array}$ & s.c. & $\begin{array}{l}\text { Prophylactic: } 0.5-1 \\
\text { nmol per injection }\end{array}$ & $\begin{array}{l}\text { Lewis rats with EAE } \\
\text { induced with guinea pig } \\
\text { MBP fusion protein }\end{array}$ & $\begin{array}{l}\text { Prophylactic or therapeutic } \\
\text { vaccination with IL-2/NAg } \\
\text { resulted in attenuation of EAE } \\
\text { course, whereas administration } \\
\text { of IL4-NAg indicated lack of } \\
\text { tolerogenic activity. }\end{array}$ \\
\hline
\end{tabular}


Table 2. Cont.

\begin{tabular}{|c|c|c|c|c|c|c|c|}
\hline Vaccine & Antigen & Targeting Ligand/Drug & Vaccination Type & Admin. Route & Admin. Dose & Animal Model & Vaccination Outcome \\
\hline GMCSF-NAg [95] & $\mathrm{MOG}_{35-55}$ & GM-CSF & $\begin{array}{l}\text { C57BL/6 mice: Prophylactic } \\
\text { 21, 14, and } 7 \text { days b.i. } \\
\text { 2D2-FIG mice: } \\
\text { Preclinical/Therapeutic: } 0, \\
\text { 7, and } 14 \text { days, or } 7 \text { and } 14 \\
\text { days, or } 14 \text { days } \text {.i. }\end{array}$ & $\begin{array}{l}\text { C57BL/6 mice: } \\
\text { s.c. } \\
\text { 2D2-FIG mice: } \\
\text { i.v. }\end{array}$ & $\begin{array}{l}\text { C57BL/6 mice: } 2 \mathrm{nmol} \\
\text { GMCSF-MOG } 35-55 \text { per } \\
\text { injection } \\
\text { 2D2-IIG mice: } 4 \mathrm{nmol} \\
\text { per injection }\end{array}$ & $\begin{array}{l}\text { C57BL/6 mice with EAE } \\
\text { induced with MOG } \\
\text { 2D2-FIG mice with a } \\
\text { transgenic MOG-specific } \\
\text { repertoire of T cells and a } \\
\text { GFP reporter of FOXP3 } \\
\text { expression }\end{array}$ & $\begin{array}{l}\text { The pretreatment with the } \\
\text { GMCSF-MOG fusion protein } \\
\text { elicited CD25+ Tregs which were } \\
\text { required for the induction of } \\
\text { tolerance. Vaccination of } \\
\text { 2D2-FIG with GMCSF-MOG } \\
\text { elicited circulating FOXP3+ Tregs } \\
\text { the number of which was } \\
\text { maintained with multiple } \\
\text { boosters. }\end{array}$ \\
\hline 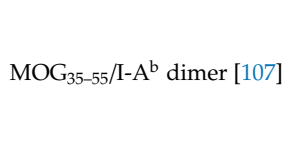 & $\mathrm{MOG}_{35-55}$ & $\mathrm{I}-\mathrm{A}^{\mathrm{b}}$ dimer & $\begin{array}{l}\text { Therapeutic: nine days p.i. } \\
\text { (treatment duration: four } \\
\text { days). }\end{array}$ & i.p. & $\begin{array}{l}12 \mathrm{nM} \mathrm{MOG}_{35-55} / \mathrm{I}-\mathrm{A}^{\mathrm{b}} \\
\text { dimer (1 } \\
\mu \mathrm{g} / \text { mouse/day) }\end{array}$ & $\begin{array}{l}\text { C57BL/ } 6 \text { female mice (6-8 } \\
\text { weeks old) with EAE } \\
\text { induced with } \text { MOG }_{35-55}\end{array}$ & $\begin{array}{l}\text { The administration of } \\
\text { MOG }_{35-55 / I-A^{b} \text { dimer resulted in }} \text { the reduction of antigen-specific } \\
\text { T cells and amelioration of EAE } \\
\text { symptoms. }\end{array}$ \\
\hline \multicolumn{8}{|c|}{ Antibodies coupled with myelin peptides } \\
\hline $\begin{array}{l}\alpha \text {-receptor-MOGp } \\
\text { mAbs [100] }\end{array}$ & $\begin{array}{l}\text { DNA for } \mathrm{MOG}_{29-59} \\
\text { (MOGp) }\end{array}$ & $\begin{array}{l}\alpha \text {-DEC mAbs } \\
\alpha \text {-Langerin mAb }\end{array}$ & $\begin{array}{l}\text { Prophylactic: transfer of } \\
\text { MOG-specific CD4+ T cells } \\
15 \text { days b.i. and admin. of } \\
\alpha \text {-receptor-MOGp mAbs } \\
14 \text { days b.i. }\end{array}$ & s.c. & $\begin{array}{l}3 \mu \mathrm{g} \text { of } \alpha \text {-receptor } \\
\text { mAbs }\end{array}$ & $\begin{array}{l}\text { C57BL/6 (B6) mice with EAE } \\
\text { induced with } \mathrm{MOG}_{35-55}\end{array}$ & \multirow{4}{*}{ 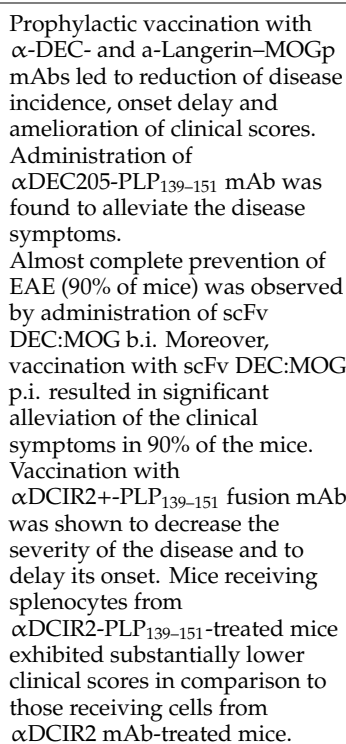 } \\
\hline $\begin{array}{l}\alpha \text { DEC205-PLP }_{139-151} \mathrm{mAb} \\
\text { [Stern et al., 2010] }\end{array}$ & $\operatorname{PLP}_{139-151}$ & anti-DEC205 & $\begin{array}{l}\text { Prophylactic: } 10 \text { or } 15 \text { days } \\
\text { b.i. }\end{array}$ & i.p. & $1 \mu \mathrm{g}$ of fusion $\mathrm{mAb}$ & $\begin{array}{l}\text { SJL/J female mice (6-10 } \\
\text { weeks old) with EAE } \\
\text { induced with PLP } \\
139-151\end{array}$ & \\
\hline scFv DEC:MOG [102] & MOG & $\begin{array}{l}\text { scFv specific for } \\
\text { DEC205 }\end{array}$ & $\begin{array}{l}\text { Prophylactic: seven and } \\
\text { three days b.i. } \\
\text { Therapeutic: oje and four } \\
\text { days after disease onset, } \\
\text { signified by a clinical score } \\
\text { equal to } 1\end{array}$ & i.v. & $\begin{array}{l}10 \mu \mathrm{g} \text { of } \\
\text { scFvDEC:MOG }\end{array}$ & $\begin{array}{l}\text { C57/B16 mice with EAE } \\
\text { induced with WSCH }\end{array}$ & \\
\hline $\begin{array}{l}\alpha \mathrm{DCIR2} 2-\mathrm{PLP} \\
\mathrm{mAb} \text { [39-151 fusion }\end{array}$ & PLP $_{139-151}$ & $\alpha$ DCIR2 & Prophylactic: 10 days b.i. & i.p. & $1 \mu \mathrm{g}$ of fusion $\mathrm{mAbs}$ & $\begin{array}{l}\text { SJL/J female mice (6-10 } \\
\text { weeks old) with EAE } \\
\text { induced with PLP } 139-151 \\
\text { (active EAE) or via adoptive } \\
\text { transfer of splenocytes from } \\
\alpha \text { DCIR2-PLP } 139-151 \text {-treated } \\
\text { mice (passive EAE) }\end{array}$ & \\
\hline
\end{tabular}


Table 2. Cont.

\begin{tabular}{|c|c|c|c|c|c|c|c|}
\hline Vaccine & Antigen & Targeting Ligand/Drug & Vaccination Type & Admin. Route & Admin. Dose & Animal Model & Vaccination Outcome \\
\hline$\alpha \mathrm{CD} 4 / \mathrm{CD} 8+\mathrm{PLP}_{139-151}[103]$ & PLP $_{139-151}$ & $\begin{array}{l}\text { Anti-CD4, anti-CD8a } \\
\mathrm{Ab}\end{array}$ & $\begin{array}{l}\text { Prophylactic: admin. of } \\
\text { mAb 21 days b.i. followed } \\
\text { by PLP } 139-151 \text { delivery } \\
\text { every other day for } 1 \text { days. } \\
\text { Therapeutic: Mice treated } \\
\text { with } \\
\alpha \text { CD4/CD8 Abs on day } 11 \\
\text { p.i. were injected with } \\
\alpha \text { CD4/CD8+PLP } 139-151 \\
\text { every other day from day } \\
12-26 .\end{array}$ & i.p. & $\begin{array}{l}100 \mu \mathrm{g} \text { of CD4-/mouse) } \\
100 \mu \mathrm{g} \text { of CD8a-/mouse } \\
25 \mu \mathrm{g} \text { PLP } 139-151 \text { per } \\
\text { injection }\end{array}$ & $\begin{array}{l}\text { SJL female mice (seven } \\
\text { weeks old) with EAE } \\
\text { induced with PLP } \\
139-151\end{array}$ & $\begin{array}{l}\alpha \mathrm{CD} 4 / \mathrm{CD} 8+\mathrm{PLP}_{139-151} \text {-treated } \\
\text { mice exhibited substantially } \\
\text { lower EAE scores and reduced } \\
\text { rate of relapses in chronic disease }\end{array}$ \\
\hline \multicolumn{8}{|c|}{ Recombinant T-cell receptor ligands (RTLs) } \\
\hline RTL342M [124] & $\mathrm{MOG}_{35-55}$ & $\begin{array}{l}\text { HLA-DR2 } \\
\text { peptide-binding } \\
\text { domains }\end{array}$ & $\begin{array}{l}\text { Therapeutic (s.c. or i.v.): } \\
\text { admin. on the day that the } \\
\text { clinical score for each } \\
\text { mouse was } \geq 2 \text {. Dily } \\
\text { admin. for mice receiving } \\
\text { multiple doses. } \\
\text { Prophylactic (s.c.): admin. } \\
\text { of } 4,9 \text {, or } 14 \text { doses within } \\
15 \text { days. EAE was induced } \\
2 \text { days after the admin. of } \\
\text { the final dose. }\end{array}$ & $\begin{array}{l}\text { i.v. } \\
\text { s.c. }\end{array}$ & $50 \mu \mathrm{g}$ of RTL342M & $\begin{array}{l}\text { HLA-DR2 positive } \\
\text { male/female mice ( } 8-12 \\
\text { weeks old) with EAE } \\
\text { induced with } \text { MOG }_{35-55}\end{array}$ & $\begin{array}{l}\text { RTL treatment was revealed to be } \\
\text { more efficient in reducing } \\
\text { paralysis when administered in } \\
\text { the form of multiple doses } \\
\text { instead of a single dose, } \\
\text { independently of the } \\
\text { administration mode. } \\
\text { Furthermore, the treatment with } \\
\text { RT342M could treat or prevent } \\
\text { relapses. Pretreatment with } \\
\text { RTL342M was shown to prevent } \\
\text { the disease. }\end{array}$ \\
\hline RTL401 [125] & PLP $_{139-151}$ & $\begin{array}{l}\alpha 1 \text { and } \beta 1 \text { domains of } \\
\text { the I- } A^{\mathrm{s}} \text { class II } \\
\text { molecule }\end{array}$ & $\begin{array}{l}\text { Upon EAE onset, daily i) i.v. } \\
\text { admin. for } 3-4 \text { days and ii) } \\
\text { s.c. admin. for } 8 \text { days. }\end{array}$ & $\begin{array}{l}\text { i.v. } \\
\text { s.c. }\end{array}$ & $100 \mu \mathrm{g}$ of RTL401 & $\begin{array}{l}\text { SJL mice (6-7 weeks of age) } \\
\text { with EAE induced with } \\
\text { PLP }_{139-151} \text { or PLP } 178-191 \text { or } \\
\text { MBP }_{48-104 .} \text { C57BL/6 X SJL) } \\
\text { F1 mice (6-7 weeks of age) } \\
\text { with EAE induced with } \\
\text { MOG }_{35-55} \text { or PLP P139-151. }\end{array}$ & $\begin{array}{l}\text { i.v. or s.c. vaccination with } \\
\text { RTL401 resulted in prevention of } \\
\text { relapses and long-term reduction } \\
\text { of clinical severity only in SJL } \\
\text { mice and C57BL/6 X SJL) F1 mice } \\
\text { with EAE induced with } \\
\text { PLP } 139-151 \text {. } \\
\text { i.v. or s.c. vaccination with }\end{array}$ \\
\hline RTL401 [126] & $\operatorname{PLP}_{139-151}$ & $\begin{array}{l}\alpha 1 \text { and } \beta 1 \text { domains of } \\
\text { the I- } A^{s} \text { class II } \\
\text { molecule }\end{array}$ & $\begin{array}{l}\text { Upon EAE onset, daily (i) } \\
\text { i.v. admin. for five days } \\
\text { and (ii) s.c. for eight days. }\end{array}$ & $\begin{array}{l}\text { i.v. } \\
\text { s.c. }\end{array}$ & $\begin{array}{l}100 \mu \mathrm{L} \text { of } 1 \mathrm{mg} / \mathrm{mL} \\
\text { RTL } 401\end{array}$ & 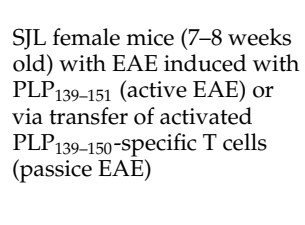 & $\begin{array}{l}\text { RTL401 was shown to effectively } \\
\text { discontinue passive EAE } \\
\text { progression, reverse its clinical } \\
\text { severity and reduce the } \\
\text { infiltration of cells into the CNS, } \\
\text { as in the treatment of active EAE. } \\
\text { Injury to axons was also } \\
\text { prevented. }\end{array}$ \\
\hline RTL551 [127] & $\mathrm{MOG}_{35-55}$ & $\begin{array}{l}\alpha 1 \text { and } \beta 1 \text { domains of } \\
\text { the I- } \mathrm{A}^{\mathrm{b}} \text { class II } \\
\text { molecule }\end{array}$ & $\begin{array}{l}\text { Upon EAE onset (days } \\
12-14 \text { for active EAE and } \\
\text { days } 7-12 \text { for passive EAE), } \\
\text { daily i.v. admin. for five } \\
\text { days. }\end{array}$ & i.v. & $\begin{array}{l}100 \mu \mathrm{L} \text { of } 1 \mathrm{mg} / \mathrm{mL} \\
\text { RTL551 }\end{array}$ & $\begin{array}{l}\text { C57BL/6 male mice (6-7 } \\
\text { weeks of age) with EAE } \\
\text { induced with MOG } 35-55 \\
\text { (active EAE) or via transfer } \\
\text { of activated cells (passive } \\
\text { EAE). }\end{array}$ & $\begin{array}{l}\text { RTL551 treatment of actively or } \\
\text { passively induced EAE resulted } \\
\text { in significant reduction of clinical } \\
\text { symptoms and spinal cord } \\
\text { lesions. }\end{array}$ \\
\hline
\end{tabular}


Table 2. Cont

\begin{tabular}{|c|c|c|c|c|c|c|c|}
\hline Vaccine & Antigen & Targeting Ligand/Drug & Vaccination Type & Admin. Route & Admin. Dose & Animal Model & Vaccination Outcome \\
\hline $\begin{array}{l}\text { RTL401, RTL402, } \\
\text { RTL403 [128] }\end{array}$ & $\begin{array}{l}\text { PLP }_{139-151} \\
\text { PLP }_{178-191} \\
\text { MBP }_{84-104}\end{array}$ & $\begin{array}{l}\alpha 1 \text { and } \beta 1 \text { domains of } \\
\text { the I-As class II } \\
\text { molecule }\end{array}$ & $\begin{array}{l}\text { At EAE onset (days 10-11), } \\
\text { when the clinical score was } \\
\geq 2 \text {, daily s.c. admin. for } 8 \\
\text { days. }\end{array}$ & s.c. & $100 \mu \mathrm{L}$ of $1 \mathrm{mg} / \mathrm{mL}$ RTL & $\begin{array}{l}\text { SJL/J female mice ( } 7-8 \text { weeks } \\
\text { old) with EAE induced with } \\
\text { WSCH or with a mixture of } \\
\text { PLP }_{139-151} \text { and PLP } \\
178-191 .\end{array}$ & $\begin{array}{l}\text { A single RTL was found capable } \\
\text { of successfully treating ongoing } \\
\text { disease induced with a mixture } \\
\text { of encephalitogenic epitopes as } \\
\text { long as the cognate T cell } \\
\text { specificity was present. }\end{array}$ \\
\hline RTL551 [106] & $\begin{array}{l}\text { rhMOG, } \\
\text { hMOG }_{35-55,} \\
\text { mMOG }_{35-55}\end{array}$ & $\begin{array}{l}\alpha 1 \text { and } \beta 1 \text { domains of } \\
\text { the I- } A^{\mathrm{b}} \text { class II } \\
\text { molecule }\end{array}$ & $\begin{array}{l}\text { At EAE onset (days 10-13), } \\
\text { when the clinical score was } \\
\geq 2 \text {, daily i.v. admin. for } \\
\text { eight days. }\end{array}$ & i.v. & $\begin{array}{l}100 \mu \mathrm{L} \text { of } 1 \mathrm{mg} / \mathrm{mL} \\
\text { RTL551 }\end{array}$ & $\begin{array}{l}\text { C57BL/6 male mice (7-8 } \\
\text { weeks old) with EAE } \\
\text { induced with rhMOG or } \\
\text { mMOG }_{35-55 .}\end{array}$ & $\begin{array}{l}\text { Vaccination with RTL551 could } \\
\text { reverse the progression of EAE, } \\
\text { reduce demyelination and } \\
\text { damage of axons without } \\
\text { however induce suppression of } \\
\text { anti-MOG Ab response. }\end{array}$ \\
\hline RTL401 [129] & $\operatorname{PLP}_{139-151}$ & $\begin{array}{l}\alpha 1 \text { and } \beta 1 \text { domains of } \\
\text { the I-As class II } \\
\text { molecule }\end{array}$ & $\begin{array}{l}\text { Upon EAE onset (days } \\
\text { 10-11), daily admin. for 1, } \\
\text { 2, or } 5 \text { days. }\end{array}$ & s.c. & $\begin{array}{l}100 \mu \mathrm{L} \text { of } 1 \mathrm{mg} / \mathrm{mL} \\
\text { RTL401 }\end{array}$ & 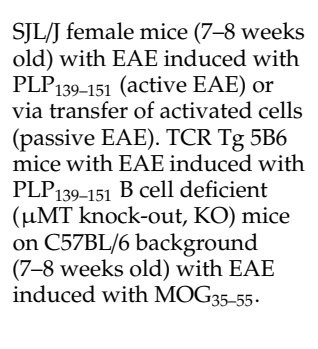 & $\begin{array}{l}\text { A new interaction between cells } \\
\text { was revealed via which the } \\
\text { RTL-equipped myeloid APCS } \\
\text { reverse EAE progression by } \\
\text { transferring tolerogenic signals } \\
\text { to cognate T lymphocytes. It was } \\
\text { also found that splenocytes } \\
\text { incubated with RTL401 exhibited } \\
\text { reduced ability to passively } \\
\text { transfer EAE. Finally, it was } \\
\text { shown that EAE can be treated by } \\
\text { RTL551 in the absence of B cells. } \\
\text { Vaccination with VG312 led to }\end{array}$ \\
\hline $\begin{array}{l}\text { VG312, VG303, } \\
\text { VG311 [108] }\end{array}$ & $\begin{array}{l}\text { MOG }_{35-55} \\
\text { MBP }_{85-99} \\
\text { CABL }^{-1}\end{array}$ & $\begin{array}{l}\alpha 1 \text { and } \beta 1 \text { domains of } \\
\text { DR2 }\end{array}$ & $\begin{array}{l}\text { Therapeutic: i.v. } \\
\text { administration for eight } \\
\text { consecutive days, } 2-4 \text { days } \\
\text { after the disease onset. }\end{array}$ & i.v. & $\begin{array}{l}100 \mu \mathrm{L} \text { of VG312, } \\
\text { VG303, VG311 }\end{array}$ & $\begin{array}{l}\text { Tg HLA-DR2 male and } \\
\text { female mice }(8-12 \text { weeks } \\
\text { old) with EAE induced with } \\
\text { MOG }_{35-55}\end{array}$ & $\begin{array}{l}\text { peptide- and dose-dependent } \\
\text { induction of long-term tolerance } \\
\text { to the encephalitogenic epitope } \\
\text { MOG }_{35-55} \text { and reversal of the } \\
\text { clinical/histological symptoms of } \\
\text { EAE }\end{array}$ \\
\hline RTL401 [130] & PLP $_{139-151}$ & $\begin{array}{l}\alpha 1 \text { and } \beta 1 \text { domains of } \\
\text { the I-A } A^{s} \text { class II } \\
\text { molecule }\end{array}$ & $\begin{array}{l}\text { Therapeutic: (i) i.v. admin. } \\
\text { for five consecutive days } \\
\text { (days 20-24) and (ii) s.c. } \\
\text { admin. for } 3 \text { days (days } \\
\text { 32-34). }\end{array}$ & $\begin{array}{l}\text { i.v. } \\
\text { s.c. }\end{array}$ & $100 \mu \mathrm{g}$ of RTL401 & $\begin{array}{l}\text { SJL/J female mice (7-8 weeks } \\
\text { old) with EAE induced with } \\
\text { PLP } 139-151 \text {. }\end{array}$ & $\begin{array}{l}\text { Administration of RTL } 401 \text { post } \\
\text { the relapsing EAE peak resulted } \\
\text { in prevention of disease relapses, } \\
\text { reduction of demyelination and } \\
\text { axonal damage. }\end{array}$ \\
\hline
\end{tabular}


Table 2. Cont.

\begin{tabular}{|c|c|c|c|c|c|c|c|}
\hline Vaccine & Antigen & Targeting Ligand/Drug & Vaccination Type & Admin. Route & Admin. Dose & Animal Model & Vaccination Outcome \\
\hline \multicolumn{8}{|c|}{ Bifunctional peptide inhibitor (BPI) } \\
\hline PLP-B7AP [131] & $\operatorname{PLP}_{139-151}$ & $\begin{array}{l}\text { B7 antisense peptide } \\
\text { (AP) derived from } \\
\text { CD28 receptor }\end{array}$ & $\begin{array}{l}\text { Prophylactic } 11,8 \text {, and } 5 \\
\text { days b.i. } \\
\text { Preclinical/Therapeutic: } 4, \\
\text { 7, and } 10 \text { days p.i. }\end{array}$ & s.c. & $\begin{array}{l}\text { Prophylactic: } 50 \text { or } 100 \\
\text { nmol } \\
\text { PLP-B7AP/injection } \\
\text { Therapeutic: } 100 \mathrm{nmol} \\
\text { PBI/injection }\end{array}$ & $\begin{array}{l}\text { SJL/J female mice (5-7 weeks } \\
\text { old) with EAE induced with } \\
\text { PLP }_{139-151}\end{array}$ & $\begin{array}{l}\text { Both prophylactic and } \\
\text { therapeutic vaccination with } \\
\text { PLP-B7AP resulted in efficient } \\
\text { suppression of EAE. Mice treated } \\
\text { with PLP-B7AP exhibited } \\
\text { significantly low demyelination. }\end{array}$ \\
\hline PLP-LABL [132] & PLP $_{139-151}$ & LABL & $\begin{array}{l}\text { Prophylactic: } 11,8 \text {, and } 5 \\
\text { days b.i. }\end{array}$ & s.c. & $100 \mathrm{nmol} /$ injection/day & $\begin{array}{l}\text { SJL/J female mice ( } 5-7 \text { weeks } \\
\text { old) with EAE induced with } \\
\text { PLP }\end{array}$ & $\begin{array}{l}\text { The vaccination with PLP-LABL } \\
\text { inhibited the inflammatory } \\
\text { response resulting in prevention } \\
\text { of BBB disruption and thus } \\
\text { inhibition of EAE onset and } \\
\text { progression. }\end{array}$ \\
\hline $\begin{array}{l}\text { PLP-LABL } \\
\text { derivatives [110] }\end{array}$ & PLP $_{139-151}$ & LABL & $\begin{array}{l}\text { Therapeutic: admin. on } \\
\text { disease onset, signified by } \\
\text { a clinical score } \geq 1 \text {, and for } \\
\text { three consecutive days } \\
\text { until the score was }<1 \text { ) }\end{array}$ & i.v. & $100 \mathrm{nmol} /$ mouse & $\begin{array}{l}\text { SJL/J (H-2S) female mice } \\
\text { (5-7 weeks old) }\end{array}$ & $\begin{array}{l}\text { Vaccination with the synthesized } \\
\text { BPI derivatives was shown to } \\
\text { efficiently inhibit EAE severity, } \\
\text { and incidence. }\end{array}$ \\
\hline PLP-LABL [133] & PLP $_{139-151}$ & LABL & $\begin{array}{l}\text { Preclinical/Therapeutic: } 4, \\
\text { 7, 10, and } 14 \text { days p.i. }\end{array}$ & i.v. & $100 \mathrm{~mol} /$ mouse & $\begin{array}{l}\text { SJL/J female mice (5-7 weeks } \\
\text { old) with EAE induced with } \\
\text { PLP } 139-151\end{array}$ & \multirow{3}{*}{$\begin{array}{l}\text { Low disease scores and incidence } \\
\text { could be observed in mice } \\
\text { vaccinated with PLP-LABL. } \\
\text { The synthesized BPI derivatives } \\
\text { were revealed to suppress EAE } \\
\text { progression after intravenous } \\
\text { administration more efficiently } \\
\text { in comparison with unmodified } \\
\text { BPI. } \\
\text { BPI-Fc fusion peptides were } \\
\text { revealed to be highly efficient in } \\
\text { suppressing EAE. The vaccinated } \\
\text { mice were not found to exhibit } \\
\text { weight loss, and featured benign } \\
\text { clinical symptoms and reduced } \\
\text { demyelination. }\end{array}$} \\
\hline $\begin{array}{l}\text { PLP-LABL } \\
\text { derivatives [134] }\end{array}$ & PLP $_{139-151}$ & LABL & $\begin{array}{l}\text { Therapeutic: admin. on } \\
\text { disease onset, signified by } \\
\text { a clinical score } \geq 1 \text {, and for } \\
\text { three consecutive days } \\
\text { until the score was }<1 \text { ) }\end{array}$ & i.v. & $100 \mathrm{nmol} /$ mouse & $\begin{array}{l}\text { SJL/J female mice (5-7 weeks } \\
\text { old) with EAE induced with } \\
\text { PLP } 139-151\end{array}$ & \\
\hline $\begin{array}{l}\text { BPI-Fc fusion peptides } \\
\text { LABL-Fc-ST-PLP and } \\
\text { LABL-Fc-ST-MOG [109] }\end{array}$ & $\begin{array}{l}\text { PLP }_{139-151} \\
\text { MOG G8-50 }_{38}\end{array}$ & LABL-Fc-ST & $\begin{array}{l}\text { Preclinical/Therapeutic: } \\
\text { four and seven days p.i. }\end{array}$ & i.v. & $25 \mathrm{nmol}$ per dose & $\begin{array}{l}\text { SJL/J mice (5-7 weeks old) } \\
\text { with EAE induced with } \\
\text { PLP }_{139-151}\end{array}$ & \\
\hline PLP-cIBR Derivatives [135] & PLP $_{139-151}$ & cIBR7 peptide & $\begin{array}{l}\text { Studies I and II: } 4,7 \text {, and } 10 \\
\text { days p.i. } \\
\text { Study III: admin. on } \\
\text { disease onset, signified by } \\
\text { a clin. score } \geq 1 \text {, and for } 3 \\
\text { consecutive days until the } \\
\text { score was }<1\end{array}$ & i.v. & $\begin{array}{l}\text { Study I: } 100 \\
\text { nmol/injection/day } \\
\text { Study II and III: } 50 \\
\text { nmol/injection/day }\end{array}$ & $\begin{array}{l}\text { SJL/J (H-2S) female mice } \\
\text { (5-7 weeks old) with EAE } \\
\text { induced with PLP } 139-151\end{array}$ & $\begin{array}{l}\text { Vaccination with PLP-CIBR, even } \\
\text { at low dose or less frequent i.v. } \\
\text { injections, resulted in significant } \\
\text { amelioration of EAE and } \\
\text { protected CNS against } \\
\text { demyelination. }\end{array}$ \\
\hline
\end{tabular}


Table 2. Cont.

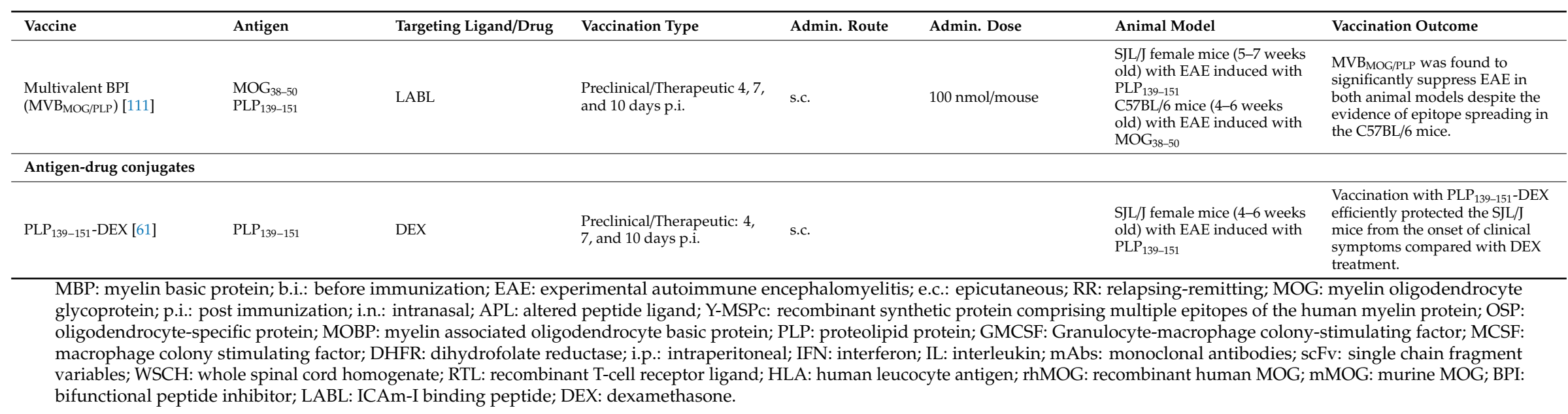




\subsubsection{Bifunctional Peptide Inhibitors (BPIs)}

Bifunctional peptide inhibitors (BPIs) are a promising novel class of peptide conjugates which are designed to selectively impede the maturation of myelin specific $\mathrm{T}$ cells. They comprise an immunodominant myelin protein epitope tethered to a signal-2-blocking peptide derived from lymphocyte function-associated antigen-1, LFA-1 (i.e., a T cell protein binding to intercellular adhesion molecule-1, ICAM-1) [109] (Figure 6). It is hypothesized that they bind at the same time to MHC-II and ICAM-1 on APCs thus inhibiting the immunological synapse formation during APC and T cell interactions [110]. The development of molecules that could target more than one epitope is crucial for the application of BPI technology in MS [111]. The performance of BPIs with respect to the induction antigen-specific immune tolerance has been studied in EAE animal models (Table 2).

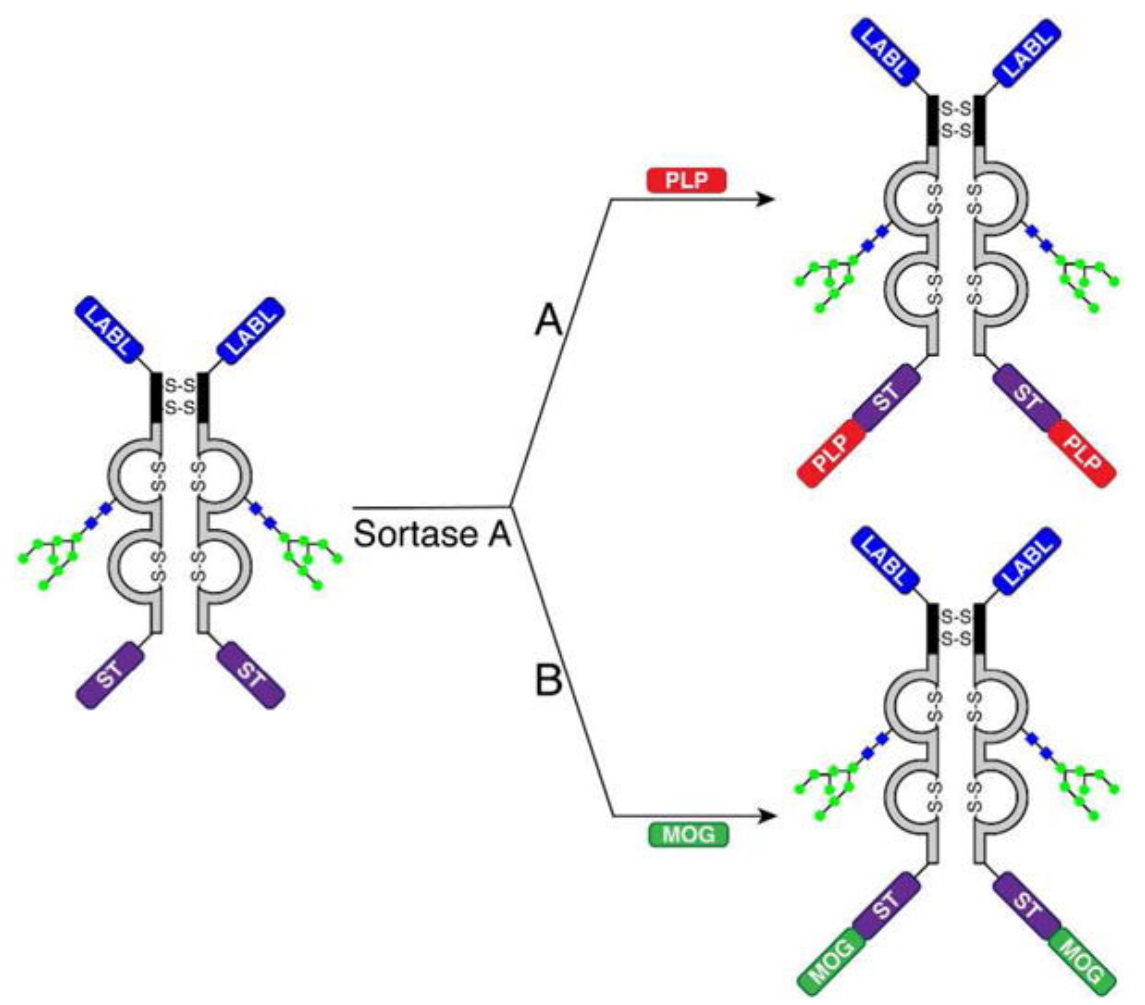

Figure 6. Sortase-mediated addition of two different antigens (A) PLP and (B) MOG to the C-terminus of LABL-Fc-ST (with permission of [109]).

\subsubsection{Antigen-Drug Conjugates}

Antigen drug conjugates (AgDCs) combine two therapeutic approaches (e.g., antigen-specific immunotherapies and immunomodulatory agents) to treat autoimmune diseases. Via chemical conjugation, the Ag could target the immunomodulatory agent to diseased cells thus minimizing side effects. AgDCs are assumed to exhibit increased affinity specificity through targeting cognate B cell receptors or endogenous autoantibodies. AgDCs formation entails the selection of an appropriate pair of antigen and immune modulator, and a linking scheme. An AgDC combing PLP $139-151$ and dexamethasone ( $\mathrm{PLP}_{139-151}$-DEX) was administered to mice induced with EAE. It was shown that the AgDC protected the mice from developing clinical symptoms during the 25-day study [61] (Table 2).

\subsection{DNA Vaccination}

Deoxyribonucleic acid (DNA) vaccination is considered a promising antigen-specific approach for the treatment of MS [91,136-138]. DNA plasmid vaccines for tolerance induction in MS comprise a bacterial plasmid encoding myelin antigen(s). Expression is controlled by a mammalian promoter and a transcription terminator. They are administered either as naked DNA or with the aid of carriers 
(e.g., cationic lipids, cationic liposomes, polymeric particles), via the intramuscular or intradermal (e.g., "gene gun" delivering gold particles coated with pDNA vaccines) administration routes. Vaccination leads to DNA uptake and gene expression by the cells at the injection site [139,140]. Induction of immune tolerance is achieved via the following potential mechanisms (Figure 7). After intramuscular injection, myocytes are the main transfected cells, as well as few APCs. Antigens are then presented by the following mechanisms: i) myocytes process and present the antigen to $\mathrm{T}$ cells leading to $\mathrm{T}$ cell anergy ii) myocytes produce and secrete antigen that is taken up by APCs, which subsequently activate $\mathrm{T}$ cells. This results in loss of $\mathrm{T}$ cell co-stimulation through CD28, downregulation of IL-2, production of IFN- $\gamma$ and reduced T cell proliferation. Intramuscular injection can also induce IFN- $\beta$ via TLR9 activation due to the presence of CPG in the plasmid backbone [140], leading to downregulation of IL-12, IFN- $\gamma$, and Th17 cell responses. Following intradermal administration, DNA is delivered directly into the resident APCs (e.g., Langerhans and dermal cells). Intradermal vaccination leads to the secretion of regulatory cytokines (e.g., IL-4, IL-10, and TGF- $\beta$ ) thus resulting in the induction of anti-inflammatory Th2 immune responses $[139,141]$. Balance between tolerance induction and inflammatory immune response can be controlled by the administration route, antigen dose, and modification of the DNA-encoded antigen [141]. Numerous data from in vivo studies with the EAE animal model (Table 3), have demonstrated the efficiency of DNA plasmid vaccines at inhibiting MS via inducing $T$ regulatory cells or anergy, clonal deletion, and immune deviation [139].

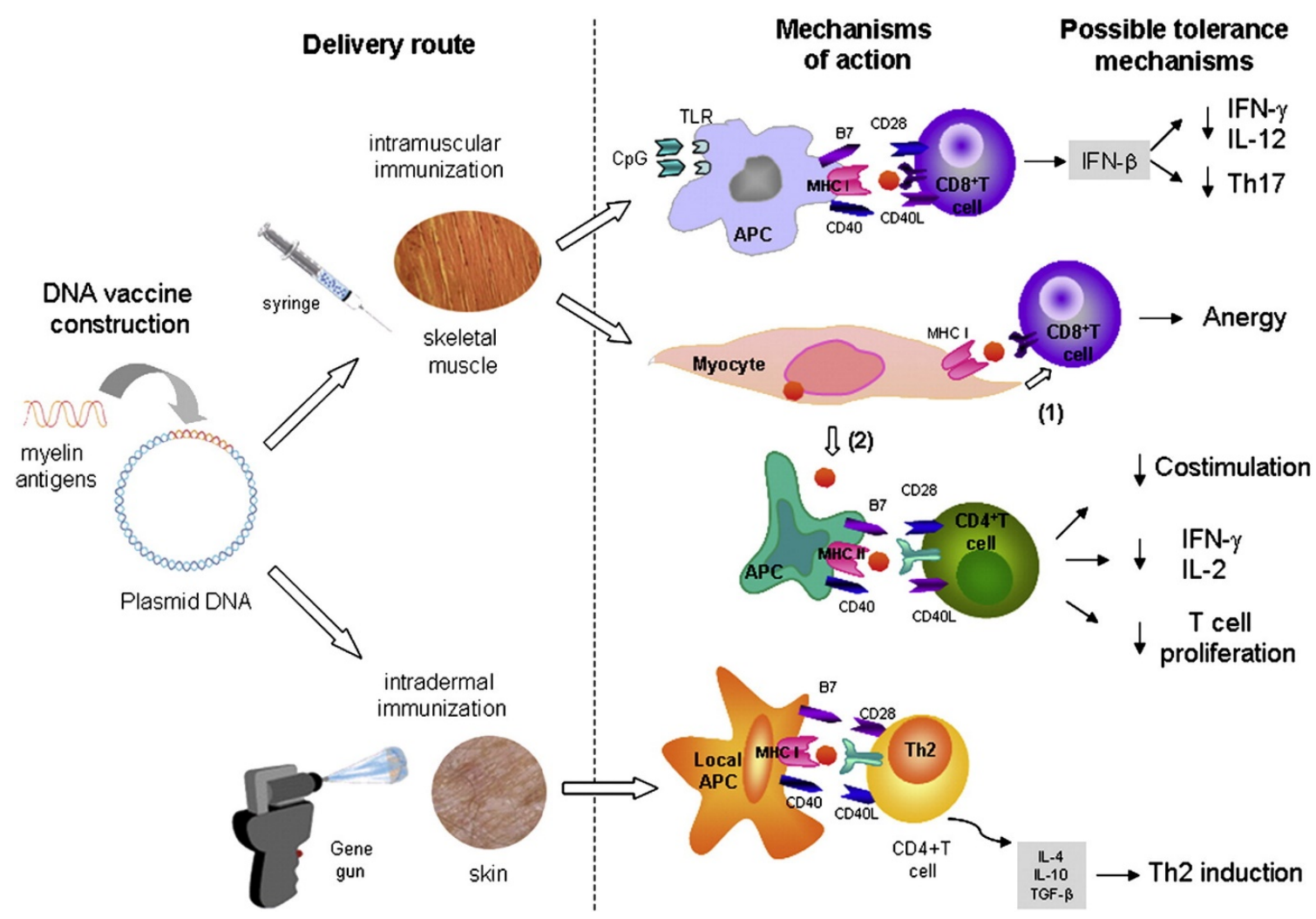

Figure 7. Mechanisms of immune tolerance induction by DNA plasmid vaccines (with permission of [139]). 
Table 3. DNA vaccination.

\begin{tabular}{|c|c|c|c|c|c|c|}
\hline Vaccine & Antigen/Immunosuppr. & Vaccination Type & Admin. Route & Admin. Dose & Animal Model & Vaccination Outcome \\
\hline $\begin{array}{l}\text { pDNA encoding IL-4 } \\
\text { pDNA encoding PLP } \\
\text { pDNA encoding } M O G \text { [142] }\end{array}$ & PLP $_{139-151}$ & $\begin{array}{l}\text { Prophylactic: } 17 \text { and } 10 \text { days } \\
\text { b.i. } \\
\text { Therapeutic: } 14 \text { and } 21 \text { days p.i } \\
\text { Co-vaccination with IL-4 } \\
\text { plasmid and MOG plasmid on } \\
\text { days } 18 \text { and } 27 \text { p.i. }\end{array}$ & i.m & $\begin{array}{l}100 \mu \mathrm{g} \text { of plasmid per } \\
\text { injection }\end{array}$ & $\begin{array}{l}\text { SJL/J mice with EAE } \\
\text { induced with PLP } \\
\text { C57BL/ } / 6 \text { mice with EAE } \\
\text { induced with } \text { MOG }_{35-55}\end{array}$ & $\begin{array}{l}\text { Co-vaccination with IL-4 and } \\
\text { PLP } 139-151 \text { plasmids significantly } \\
\text { protected against induction of } \\
\text { EAE. } \\
\text { Co-vaccination with IL-4 plasmid } \\
\text { and MOG plasmid reversed } \\
\text { ongoing EAE. }\end{array}$ \\
\hline $\begin{array}{l}\text { pMOG 91-108 } \\
\text { pK0-MOG } 91-108 \text { (lacking } \\
\text { CpG motifs) [143] }\end{array}$ & MOG $_{91-108}$ & Prophylactic: three weeks b.i. & i.m. & $200 \mu \mathrm{g}$ DNA/injection & $\begin{array}{l}\text { LEW.1AV1 (RT1av1) female } \\
\text { rats (4-5 weeks old) with } \\
\text { EAE induced with } \\
\text { MOG } 91-108\end{array}$ & $\begin{array}{l}\text { Vaccinated rats were protected } \\
\text { against EAE. }\end{array}$ \\
\hline $\begin{array}{l}\text { pDNA encoding IL-10 } \\
\text { pDNA encoding } \\
\text { MBP }_{68-86}[144]\end{array}$ & $\mathrm{MBP}_{68-86}$ & Admin. at the disease onset & & & $\begin{array}{l}\text { Female Lewis rats }(\sim 6 \\
\text { weeks old) with EAE } \\
\text { induced with } \mathrm{MBP}_{68-86} \text { or } \\
\text { MBP }_{87-99} \text {, or with EAN } \\
\text { induced with } \text { P2 }_{57-81}\end{array}$ & 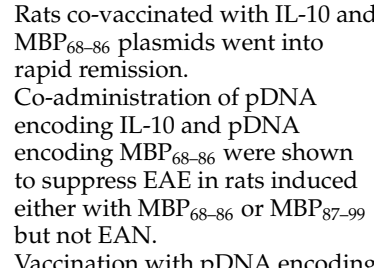 \\
\hline $\begin{array}{l}\text { pZZ/MOG } 91-108 \\
\text { pMOG91-108 } \\
\text { pK0-MOG1-108 } \\
\text { pK3-MOG91-108 [145] }\end{array}$ & $\mathrm{MOG}_{91-108}$ & Prophylactic: 3-4 weeks b.i. & i.m. & $\begin{array}{l}200 \mu g \text { DNA/injection } 100 \\
\mu \mathrm{g} \text { of CpG DNA were } \\
\text { added to pMOG } 91-108 \\
\text { before the injection }\end{array}$ & $\begin{array}{l}\text { Female LEW.1AV1 (RT1av1) } \\
\text { rats ( } 4-5 \text { weeks old) and } \\
\text { female DA rats with EAE } \\
\text { induced with } \text { MOG }_{91-108}\end{array}$ & $\begin{array}{l}\text { Vaccination with pDNA encoding } \\
\text { MOG G1-108 (lacking the ZZ gene) } \\
\text { reduced clinical symptoms of } \\
\text { EAE and mortality in rats with } \\
\text { different genetic background } \\
\text { sharing the same MHC. }\end{array}$ \\
\hline $\begin{array}{l}\text { DNA encoding MBP, PLP, } \\
\text { MOG, MAG and IL-4- [10] }\end{array}$ & $\begin{array}{l}\text { MBP, PLP, MOG, } \\
\text { MAG/GpG ODN }\end{array}$ & $\begin{array}{l}\text { Therapeutic: admin. at the } \\
\text { peak of acute EAE, when mice } \\
\text { exhibited paralysis }\end{array}$ & $\begin{array}{l}\text { i.m. } \\
\text { i.p. }\end{array}$ & $\begin{array}{l}0.025 \mathrm{mg} \text { of each myelin } \\
\text { peptide plasmid, } 0.05 \mathrm{mg} \text { of } \\
\text { IL-4 plasmid and } 0.05 \mathrm{mg} \text { of } \\
\text { GpG ODN }\end{array}$ & $\begin{array}{l}\text { Female SJL/J and C57BL/6 } \\
\text { (B6) mice (8-12 weeks old) } \\
\text { with EAE induced with } \\
\text { PLP }_{139-151 \text { or } \text { MOG }_{35-55}}\end{array}$ & $\begin{array}{l}\text { Administration of myelin } \\
\text { cocktail/IL-4 plasmids and the } \\
\text { immunosuppressant GpG ODN } \\
\text { resulted in dramatic } \\
\text { improvement of the disease in } \\
\text { mice having either chronic } \\
\text { relapsing or chronic progressive } \\
\text { EAE. }\end{array}$ \\
\hline $\begin{array}{l}\text { pMOG 91-108 } \\
\text { pMOG-IFN- } \beta \\
\text { pMOG-scr [146] }\end{array}$ & MOG91-108 & Prophylactic: three weeks b.i. & i.m. & $200 \mu \mathrm{g}$ DNA/injection & $\begin{array}{l}\text { Female LEW.1AV1 (RT1av1) } \\
\text { rats (4-5 weeks old) and } \\
\text { female DA rats with EAE } \\
\text { induced with } \text { MOG G1-108 }^{\text {ind }}\end{array}$ & $\begin{array}{l}\text { The suppressive ability of DNA } \\
\text { vaccination was found to be } \\
\text { abrogated via silencing IFN- } \beta \text {. }\end{array}$ \\
\hline p2MOG35 [147] & 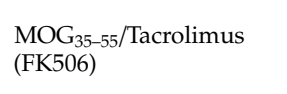 & $\begin{array}{l}\text { Preclinical/Therapeutic: three } \\
\text { and } 17 \text { days p.i. }\end{array}$ & i.m. & $\begin{array}{l}100 \mu \mathrm{g} \text { of p2MOG35/mouse } \\
10 \mu \mathrm{g} \text { of FK506/mouse }\end{array}$ & $\begin{array}{l}\text { Female C57BL/ } 6 \text { mice (6-8 } \\
\text { weeks old) with EAE } \\
\text { induced with } \mathrm{MOG}_{35-55}\end{array}$ & $\begin{array}{l}\text { Co-administration of p2MOG35 } \\
\text { with FK506 was shown to } \\
\text { effectively meliorate EAE in mice. }\end{array}$ \\
\hline
\end{tabular}


Table 3. Cont.

\begin{tabular}{|c|c|c|c|c|c|c|}
\hline Vaccine & Antigen/Immunosuppr. & Vaccination Type & Admin. Route & Admin. Dose & Animal Model & Vaccination Outcome \\
\hline $\begin{array}{l}\text { pVAX-PLP, } \\
\text { pVAX-MOG [148] }\end{array}$ & PLP, MOG & $\begin{array}{l}\text { Prophylactic: four or } 12 \text { weeks } \\
\text { b.i. }\end{array}$ & i.m. & $\begin{array}{l}20 \mu \mathrm{g} \text { pVAX-PLP, } \\
\text { pVAX-MOG }\end{array}$ & $\begin{array}{l}\text { Female SJL/J (9H-2) mice ( } 6 \\
\text { weeks old) } \\
\text { with EAE induced with } \\
\text { PLP }_{139-151} \text { C } 57 / \text { B6 mice with } \\
\text { EAE induced with } \\
\text { MOG }_{35-55}\end{array}$ & $\begin{array}{l}\text { EAE was found to be exacerbated } \\
\text { in mice vaccinated with } \\
\text { pVAX-PLP } 4 \text { weeks prior to } \\
\text { immunization whereas both } \\
\text { clinical and pathological } \\
\text { symptoms were suppressed in } \\
\text { mice vaccinated } 12 \text { weeks prior to } \\
\text { EAE induction. In mice } \\
\text { vaccinated with pVAX-MOG, } \\
\text { either four or } 12 \text { weeks prior to } \\
\text { immunization, EAE was shown } \\
\text { to be significantly suppressed. }\end{array}$ \\
\hline
\end{tabular}




\subsection{Cell-Based Vaccination}

\subsubsection{Antigen-Specific Tolerogenic Dendritic Cells (tolDCs)}

Dendritic cells (DCs) have a critical role in initiating adaptive immune responses in order to eliminate invading pathogens as well as in inducing tolerance towards innocuous components so as to maintain immune homeostasis [149]. Tolerogenic dendritic cells (TolDCs) are considered an attractive therapeutic approach for the induction of antigen-specific tolerance in autoimmune diseases [150,151]. To date various protocols have been developed for the in vitro generation of clinical-grade tolerogenic DCs ([35,152] (Figure 8) [153]) for antigen-specific immunotherapies. Autologous peripheral blood mononuclear cells (PBMCs) or bone marrow derived cells (BMDCs) are differentiated into tolDCs by numerous pharmacologic agents (e.g., immunosuppressive drugs such as rapamycin, cytotoxic T-lymphocyte-associated protein 4 (CTLA-4) Ig, corticosteroids; cyclic AMP inducers such as prostaglandin E2 and histamine; chemicals like vitamin D3, aspirin, etc.; proteins and neuropeptides like HLA-G, vasoactive intestinal peptide, etc.) and immunomodulatory cytokines (e.g., IL-10, TGF and low doses of GM-CSF) $[150,153]$ and are further pulsed in vitro with autoantigens, encephalitogenic peptides, apoptotic cells, etc. [153]. tolDCs can display an immature or a semi-mature phenotype which is characterized by altered cytokine production and low expression of MHC and co-stimulatory molecules [150].

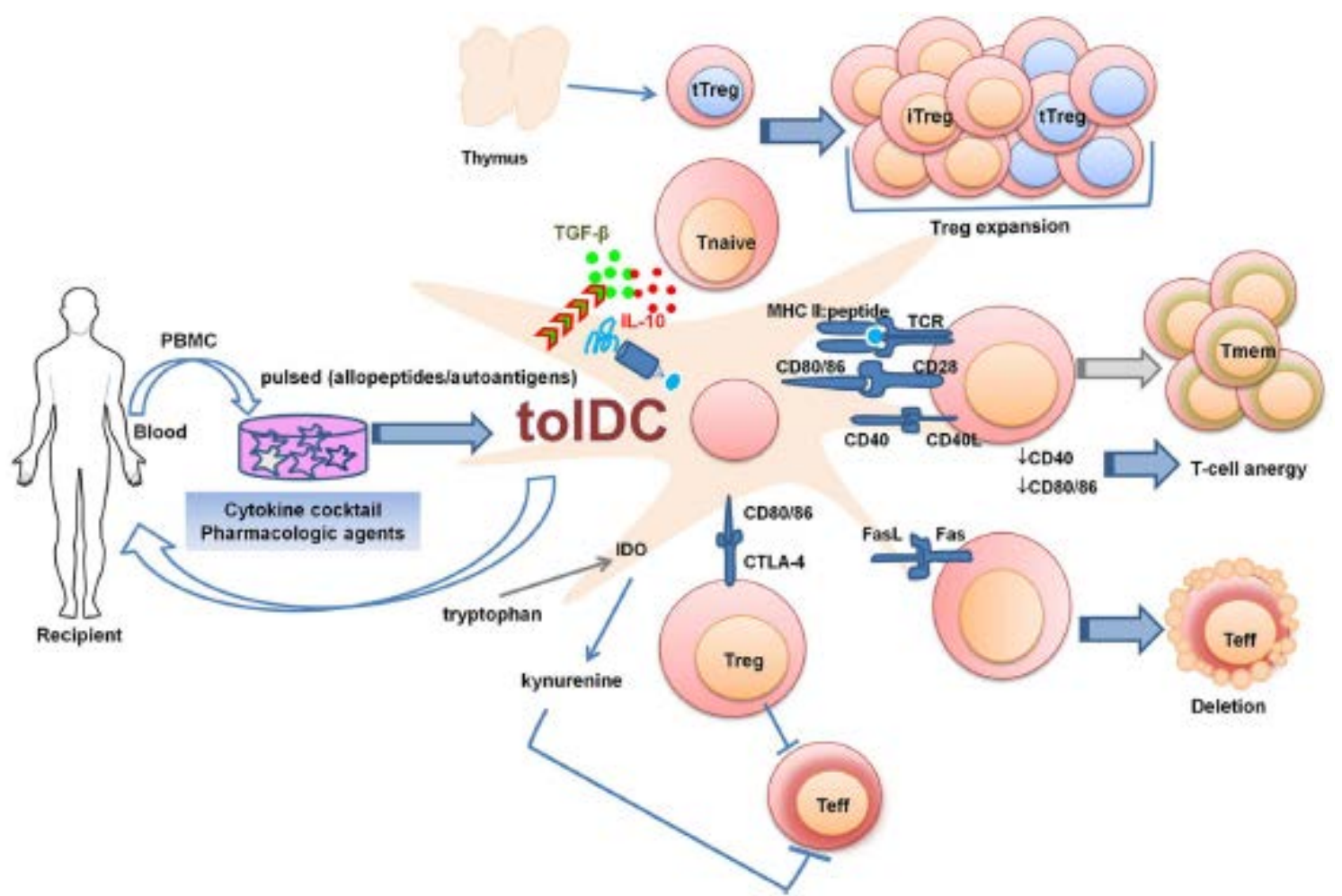

Figure 8. Strategies to generate tolDCs for clinical therapeutics [153].

Depending on the experimental protocol, the molecules used to induce tolerogenic properties, and the targeted cell population, tolDCs use different mechanisms of regulation to induce tolerance (Figure 8), including conversion to a regulatory $\mathrm{T}$ cell phenotype, induction of anergy, and antigen-specific deletion of T cell clones $[19,35,150,152-154]$. Lately, their ability to induce regulatory B cells secreting IL-10 has been also demonstrated [152]. TolDCs can be categorized into induced tolDCs (itDCs) (i.e., those acquiring their tolerogenic features in vitro or in vivo as described above and contribute to the maintenance of tolerance even under proinflammatory conditions) and natural tolDCs (ntDCs) (i.e., 
DCs present in the spleen and other lymphoid sites which inherently aid to establish tolerance in the absence of danger signals) [155].

The therapeutic potential of tolDCs has been demonstrated in the EAE model of MS (Table 4) (Figure 9). A key challenge is the translation of the in vivo results to humans. In this respect, it will be critical to correlate clinical efficiency with variation of immunological parameters and, accordingly, to define the best administration route and the effective dose of cells for this route [152]. Progress in the scientific areas of recombinant protein expression, genome editing and nanotechnology-based drug delivery systems, combined with improved immunization protocols, could further improve the promising tolDC vaccination in the furure [150].
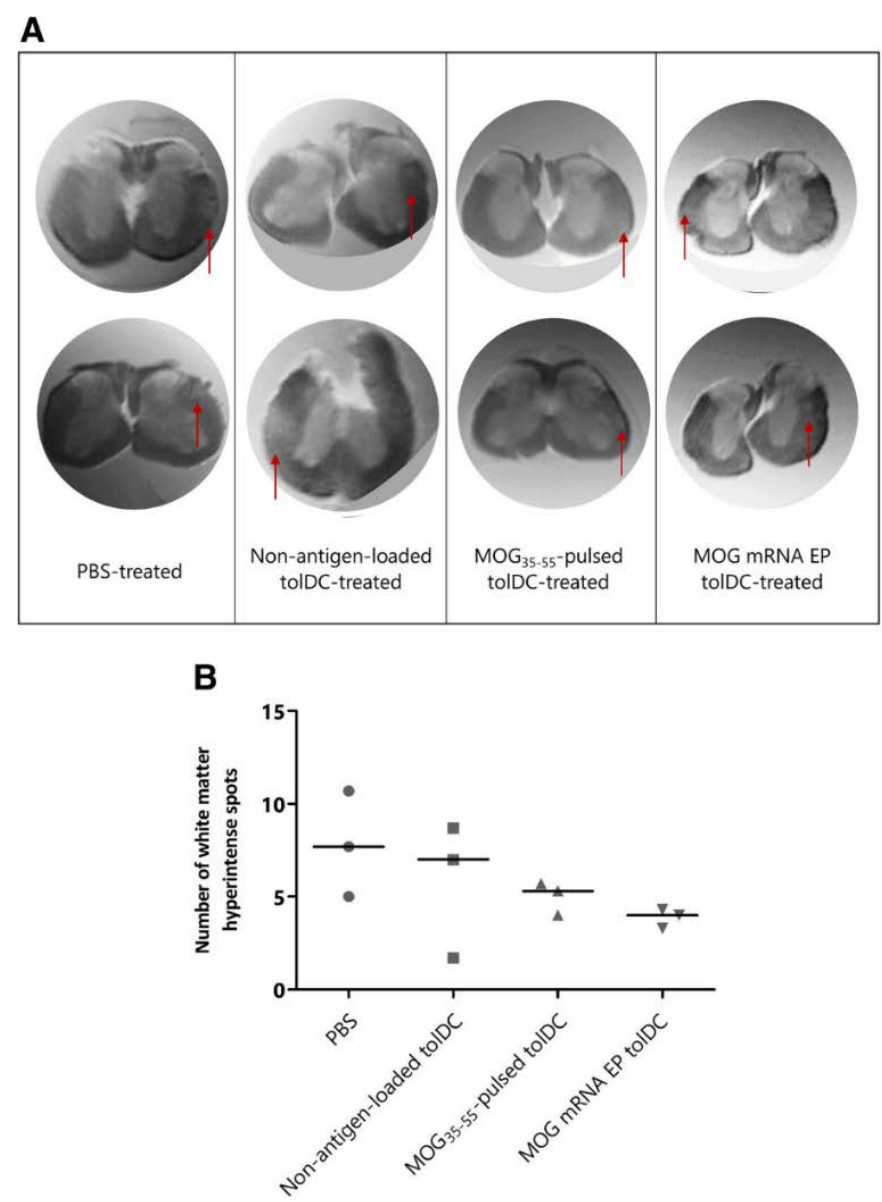

Figure 9. Evaluation of inflammatory lesion load within the spinal cord of tolDC-treated and PBS-treated mice using ex vivo MRI imaging. (A) Representative MRI of spinal cord with hyperintense white matter spots marked with a red arrow. Two representative axial slices are shown per treatment group. (B) The total number of hyperintense white matter spots along the entire spinal cord was quantified as a measure of lesion load in three mice per treatment group. Results are presented as individual scores for hyperintense spots with median [154].

\subsubsection{T Cell Vaccination (TCV)}

$\mathrm{T}$ cell vaccination involves the extraction of myelin reactive $\mathrm{T}$ cells from MS patients and their re-injection after irradiation in order to induce protective immunity $[12,80,141,156]$. To prepare T-cell vaccines, CSF mononuclear cells or blood PBMC's are stimulated with myelin antigen, and are then expanded specifically for the selected myelin peptide till an adequate population of cloned $\mathrm{T}$ cells is available. The latter are activated with antigen, and attenuated via exposure to radiation (6-12,000 Rads) to avoid proliferation after injection $[156,157]$. In clinic, the TCV protocol also involves multi-epitope TCR peptides [80]. TCV has been found to specifically suppress autoreactive T cells in MS via induction 
of a complicated anti-ergotypic and anti-idiotypic regulatory network or T cell deletion $[80,91,156]$. Various typical cytokines and lymphocyte phenotype transfer have been shown to participate in the depletion of the autoreactive $\mathrm{T}$ cells and the reversion of abnormal autoimmune responses [80] (Figure 10).

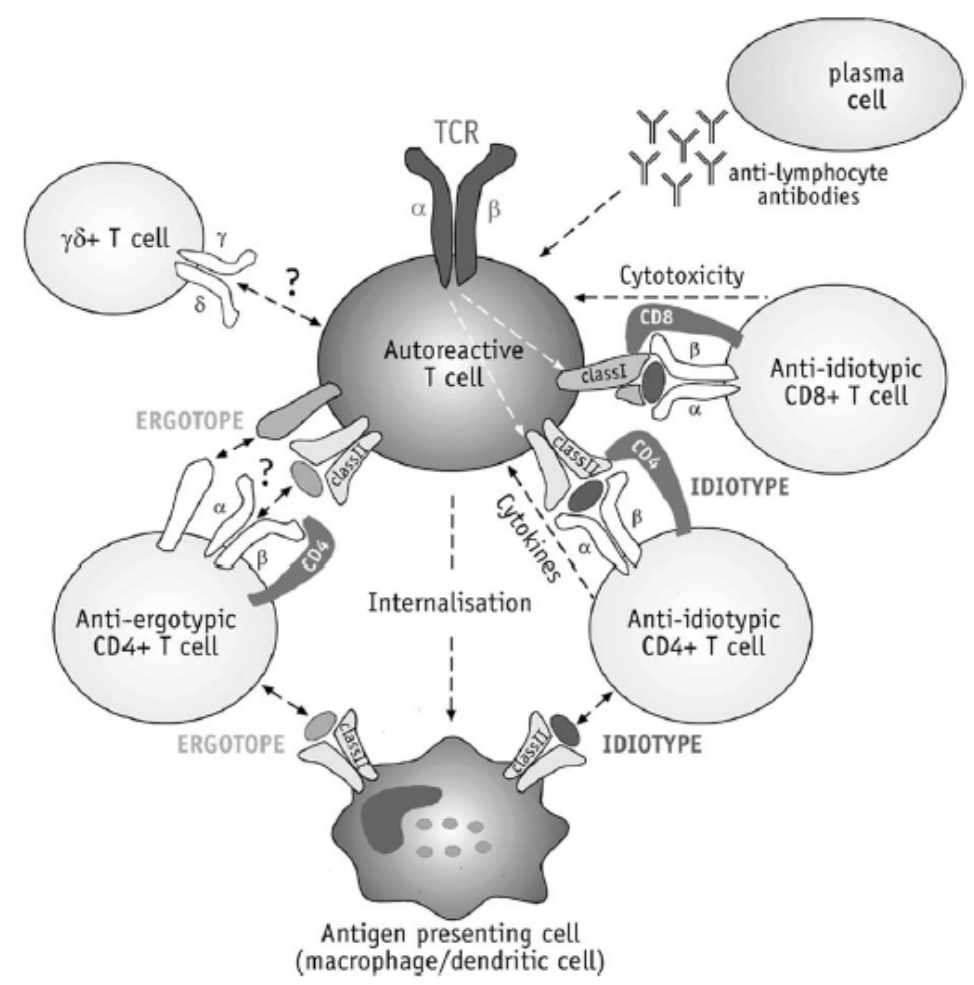

Figure 10. Complexity of anti-vaccine responses induced by TCV (with permission of [29]).

\subsubsection{Antigen-Coupled Cells}

Intact proteins (e.g., myelin proteins) as well as multiple peptides (e.g., MBP, PLP, and MOG derived peptides) can be coupled to a single cell (e.g., splenocyte $[158,159]$, erythrocyte $[67,160])[86]$ (Table 4), thus permitting concurrent targeting of various T-cell specificities. This could be critical for antigen-specific immunotherapy in MS, where immune tolerance to multiple T-cell epitopes is considered necessary for the disease treatment due to epitope spreading. Contrary to protein/peptide-induced tolerance, vaccination with protein/peptide-coupled cells lowers the risk of anaphylaxis, since the antigen is chemically crosslinked to the cell surface. Vaccination with antigen-coupled cells has been found to prevent the active- and passive-transfer. Finally, tolerance induction with Ag-coupled cells can help define immunodominant myelin antigens, since the disease progression can be impeded by cells coupled with the spread epitope [75]. 
Table 4. Cell-based vaccination.

\begin{tabular}{|c|c|c|c|c|c|c|}
\hline Cells & Inductive Agent/Peptide & Vaccination Type & Admin. Route & Admin. Dose & Animal Model & Vaccination Outcome \\
\hline \multicolumn{7}{|c|}{ Tolerogenic Dendritic cells (tolDCs) } \\
\hline $\begin{array}{l}\text { BMDCs from C57BL/6 } \\
\text { mice [161] }\end{array}$ & Atorvastatin/MOG $35-55$ & $\begin{array}{l}\text { Preclinical/Therapeutic: } \\
\text { days five and } 13 \text { p.i. }\end{array}$ & i.p. & $1 \times 10^{6}$ cells per injection & $\begin{array}{l}\text { Female C57BL/ } 6 \text { mice (8-10 } \\
\text { weeks old) with EAE } \\
\text { induced with } \text { MOG }_{35-55}\end{array}$ & $\begin{array}{l}\mathrm{MOG}_{35-55} \text {-specific tolDCs } \\
\text { successfully ameliorated clinical } \\
\text { Symptoms in mice with EAE. }\end{array}$ \\
\hline BMDCs [162] & mytomycin $\mathrm{C} / \mathrm{MOG}_{196-204}$ & $\begin{array}{l}\text { Admin. of MOG196-pulsed } \\
\mathrm{Kb}-/-\mathrm{Db}-/-\mathrm{DCs} \text { to } \\
\text { C57BL/6 (B6) mice one } \\
\text { week b.i. and one p.i. } \\
\text { Admin. of MOG196-pulsed } \\
\text { B6 DCs to C57BL/6 mice } \\
\text { three days b.i. and two and } \\
\text { seven days p.i. }\end{array}$ & s.c. & $1 \times 10^{6}$ cells per injection & $\begin{array}{l}\text { Female C57BL/6 (B6) ( }(8-10 \\
\text { weeks old) with EAE } \\
\text { induced with MOG } \text { MOF-55 }_{35}\end{array}$ & $\begin{array}{l}\text { Administration of MOG196-pulsed } \\
\mathrm{Kb}-/-\mathrm{Db}-/-\mathrm{DCs} \text { or } \\
\text { MOG196-pulsed DCs ameliorated } \\
\text { EAE in mice. }\end{array}$ \\
\hline Murine BMDCs [154] & $\begin{array}{l}1 \alpha, 25 \text {-dihydroxy-vitamin } \\
\text { D3/MOG-encoding mRNA } \\
\text { or MOG } 35-55\end{array}$ & $\begin{array}{l}\text { Therapeutic: } 13,17 \text {, and } \\
21 \text { days p.i. }\end{array}$ & i.v. & $1 \times 10^{6}$ cells per injection & $\begin{array}{l}\text { Female C57BL/6JOlaHsd } \\
\text { mice (8-10 weeks old) with } \\
\text { EAE induced with } \\
\text { MOG }_{35-55}\end{array}$ & $\begin{array}{l}\text { Vaccination with tolDCs } \\
\text { electroporated with MOG-encoding } \\
\text { mRNA or } \text { MOG G } 35-55 \text { stabilized the } \\
\text { clinical signs of the disease already } \\
\text { from the first injection. MRI } \\
\text { examination of hyperintense spots } \\
\text { present along the spinal cord of } \\
\text { mice was found to be in line with } \\
\text { the clinical score (Figure 9). } \\
\text { Administration of }\end{array}$ \\
\hline BMDCs [163] & $\begin{array}{l}\text { CD40-specific and } \\
\text { p19-specific shRNA } \\
\text { encoding lentiviral } \\
\text { vectors/pyromycin/MOG } \\
\text { 35-55 }\end{array}$ & $\begin{array}{l}\text { Preclinical/Thereapeutic: } 3 \text {, } \\
\text { 5, and } 7 \text { days p.i. }\end{array}$ & i.v. & $2 \times 10^{6}$ cells per injection & $\begin{array}{l}\text { C57BL/6 mice with EAE } \\
\text { induced with } \text { MOG }_{35-55}\end{array}$ & $\begin{array}{l}\text { MOG35-55-pulsed and lentiviral } \\
\text { transduced BMDCs led to } \\
\text { significant decrease in the clinical } \\
\text { symptoms of EAE in mice. The } \\
\text { highest decrease in the clinical } \\
\text { scores was observed with the } \\
\text { administration of co-transduced } \\
\text { BMDCs (BoLV-DCs). }\end{array}$ \\
\hline BMDCs [164] & Vitamin D3/MOG $40-55$ & $\begin{array}{l}\text { Preclinical/Therapeutic: } \\
\text { two and five days p.i., or } \\
\text { five and nine days p.i. or } 15, \\
19,23 \text {, and } 33 \text { days p.i. }\end{array}$ & i.v. & 2 or $4 \times 10^{6}$ cells & $\begin{array}{l}\text { Female C57BL/6J mice (8-10 } \\
\text { weeks old) with EAE } \\
\text { induced with } \text { MOG }_{40-55}\end{array}$ & $\begin{array}{l}\mathrm{MOG}_{40-55} \text { - specific TolDCs were } \\
\text { found to succeed in reducing EAE } \\
\text { incidence and ameliorating its } \\
\text { clinical signs. } \\
\text { It was shown that }\end{array}$ \\
\hline BMDCs [165] & $\begin{array}{l}\text { Vitamin } \\
\text { D3/MOG } 40-55 / \text { cryopreserved }\end{array}$ & & i.v. & 2 or $4 \times 10^{6}$ cells & $\begin{array}{l}\text { Female C57BL/6J mice (8-10 } \\
\text { weeks old) with EAE } \\
\text { induced with } \mathrm{MOG}_{40-55}\end{array}$ & $\begin{array}{l}\mathrm{MOG}_{40-55} \text { - specific TolDCs } \\
\text { maintain their tolerogenic } \\
\text { properties and can efficiently } \\
\text { ameliorate the clinical symptoms of } \\
\text { EAE. }\end{array}$ \\
\hline Murine BMDCs [166] & Tofacitinib/MOG $35-55$ & $\begin{array}{l}\text { Therapeutic: } 7,11 \text {, and } 15 \\
\text { days p.i. }\end{array}$ & i.v. & & $\begin{array}{l}\text { Twelve-week Female } \\
\text { C57BL/6 mice (12 weeks } \\
\text { old) with EAE induced } \\
\text { with } \text { MOG }_{35-55}\end{array}$ & $\begin{array}{l}\mathrm{MOG}_{35-55} \text { - specific TolDCs } \\
\text { efficiently dampened EAE severity } \\
\text { and progression. }\end{array}$ \\
\hline
\end{tabular}


Table 4. Cont

\begin{tabular}{|c|c|c|c|c|c|c|}
\hline Cells & Inductive Agent/Peptide & Vaccination Type & Admin. Route & Admin. Dose & Animal Model & Vaccination Outcome \\
\hline BMDCs [167] & $\begin{array}{l}\text { 1,25-dihydroxyvitamin } \\
\mathrm{D}_{3} / \mathrm{MOG}_{35-55}\end{array}$ & $\begin{array}{l}\text { Therapeutic: } 10,13 \text {, and } 16 \\
\text { days p.i. }\end{array}$ & i.v. & & $\begin{array}{l}\text { Female C57BL/6 mice (6-8 } \\
\text { weeks old) with EAE } \\
\text { induced with } \text { MOG }_{35-55}\end{array}$ & $\begin{array}{l}\text { Vitamin D3 treated } \\
\text { MOG }_{35-55} \text {-specific. TolDCs } \\
\text { succeeded in postponing the } \\
\text { disease onset and reducing its } \\
\text { clinical scores. }\end{array}$ \\
\hline DCs [168] & Estriol (E3)/MOG $35-55$ & Prophylactic: one day b.i. & i.v. & $8-10 \times 10^{6}$ cells per mouse & $\begin{array}{l}\text { Female C57BL/6 (H-2b) } \\
\text { mice ( } 4-6 \text { weeks old) with } \\
\text { EAE induced with } \\
\text { MOG }_{35-55}\end{array}$ & $\begin{array}{l}\text { Mice vaccinated with E3 } \\
\text { MOG }_{35-55} \text { - specific TolDCs } \\
\text { exhibited a reduced cumulative } \\
\text { clinical score and EAE severity. } \\
\text { They also avoided relapses and } \\
\text { development of chronic disease. } \\
\text { Vaccination with }\end{array}$ \\
\hline $\begin{array}{l}\text { BMDCs matured with } \\
\text { TNF- } \alpha \text { [169] }\end{array}$ & $/ \mathrm{MOG}_{35-55}$ & $\begin{array}{l}\text { Prophylactic: } 7,5,3 \text {, and } 1 \\
\text { days b.i. } \\
\text { Preclinical: one day p.i. }\end{array}$ & i.v. & $\begin{array}{l}2-2.5 \times 10^{6} \text { cells per } \\
\text { injection Rat anti-mouse } \\
\text { IL-10R mAb: } 0.5 \mathrm{mg} \\
\text { equivalents per mouse }\end{array}$ & $\begin{array}{l}\text { C57Bl/6 mice with EAE } \\
\text { induced with } \text { MOG }_{35-55}\end{array}$ & $\begin{array}{l}\mathrm{MOG}_{35-55} \text { - specific TNF/DCs } \\
\text { improved the clinical disease score. } \\
\text { Pulsing of TNF- } \alpha / \mathrm{DCs} \text { with an } \\
\text { unrelated peptide did not succeed } \\
\text { in preventing the disease. }\end{array}$ \\
\hline DCs [170] & $\begin{array}{l}\text { /in vivo pulsing in Lewis } \\
\text { rats with EAE induced with } \\
\mathrm{MBP}_{68-86}\end{array}$ & $\begin{array}{l}\text { Prophylactic: four weeks } \\
\text { b.i. }\end{array}$ & s.c. & $1 \times 10^{6}$ cells per rat & $\begin{array}{l}\text { Male Lewis rats with EAE } \\
\text { induced with } \mathrm{MBP}_{68-86}\end{array}$ & $\begin{array}{l}\text { Injection of EAE DCs to rats resulted } \\
\text { in induction of immune tolerance } \\
\text { against the disease as demonstrated } \\
\text { by delayed onset and marked } \\
\text { decrease of the mean clinical score. }\end{array}$ \\
\hline \multicolumn{7}{|l|}{$\mathrm{T}$ cell-based vaccination } \\
\hline Ob2F3 Tregs [171] & $\begin{array}{l}\text { Retrovirally transduced } \\
\text { pre-stimulated naïve CD4+ } \\
\text { Tcells from peripheral } \\
\text { blood mononuclear cells } \\
\text { (PBMCs) of healthy donors } \\
\text { using Ob2F3. }\end{array}$ & $\begin{array}{l}\text { Preclinical/Therapeutic: } \\
\text { seven days p.i. }\end{array}$ & i.v. & $2 \times 10^{6}$ cells & $\begin{array}{l}\text { Male and female } \\
\text { HLA-DR15 transgenic mice } \\
\text { (4.5-7.5 months old) with } \\
\text { EAE induced with } \\
\text { MOG }_{35-55}\end{array}$ & $\begin{array}{l}\text { Ob2F3 Tregs were shown to } \\
\text { significantly ameliorate } \mathrm{MOG}_{35-55} \\
\text { induced EAE via bystander } \\
\text { suppression. }\end{array}$ \\
\hline $\begin{array}{l}\text { MBP-specific T-cell lines } \\
\text { (e.g., B12 and } \\
\text { B12-GFP) [157] }\end{array}$ & & $\begin{array}{l}\text { Prophylactic: admin. three } \\
\text { times at weekly intervals, } \\
\text { with the last injection } 10 \text { or } \\
\text { seven days b.i. }\end{array}$ & s.c. & $\begin{array}{l}1 \times 10^{7} \text { activated and } \\
\text { irradiated T cells }\end{array}$ & $\begin{array}{l}\text { Female Lewis rats (6-8 } \\
\text { weeks old) with EAE } \\
\text { induced via i.v. injection of } \\
\text { antigen stimulated T cells. }\end{array}$ & $\begin{array}{l}\text { Vaccination with MBP-specific T cell } \\
\text { lines inhibited the development of } \\
\text { EAE clinical symptoms. }\end{array}$ \\
\hline
\end{tabular}


Table 4. Cont.

\begin{tabular}{|c|c|c|c|c|c|c|}
\hline Cells & Inductive Agent/Peptide & Vaccination Type & Admin. Route & Admin. Dose & Animal Model & Vaccination Outcome \\
\hline \multicolumn{7}{|c|}{ Hematopoietic stem cells (HSCs) } \\
\hline $\begin{array}{l}\text { DC-MOG } \\
\text { vector-transduced } \\
\text { BM-HSC [172] }\end{array}$ & $\begin{array}{l}\text { Ex vivo modification of } \\
\text { HSCs with SIN lentivirus } \\
\text { vectors which } \\
\text { transcriptionally target the } \\
\text { expression of myelin } \\
\text { peptides to DCs. }\end{array}$ & $\begin{array}{l}\text { Prophylactic: Lethally } \\
\text { Irradiated (10.5 Gy) mice } \\
\text { were transplanted with } \\
\text { DC-MOG transduced } \\
\text { BM-HSCs eight weeks b.i. } \\
\text { BM chimeras received } \\
\text { neomycin treatment for } \\
\text { three weeks post } \\
\text { transplantation. }\end{array}$ & i.v. & $1-3 \times 10^{6}$ cells per mouse & $\begin{array}{l}\text { C57BL/6 mice with EAE } \\
\text { induced with MOG } \\
\text { peptide. }\end{array}$ & $\begin{array}{l}\text { The transplantation of DC-MOG } \\
\text { vector-transduced BM-HSC was } \\
\text { found to completely protect mice } \\
\text { from developing EAE even in cases } \\
\text { of transplantation } 6 \text { months b.i. In } \\
\text { agreement with the clinical } \\
\text { observations, no histological signs } \\
\text { of the disease such as } \\
\text { demyelination, damage of axons, } \\
\text { etc. could be detected in the } \\
\text { tolerized mice. }\end{array}$ \\
\hline \multicolumn{7}{|l|}{ Bone marrow cells (BMC) } \\
\hline $\begin{array}{l}\text { BMCs expressing } \\
\text { MOG }_{40-55}[173]\end{array}$ & liMOG & $\begin{array}{l}\text { Prophylactic: mice were } \\
\text { transplanted with BMCs } \\
\text { transduced with liMOG } 21 \\
\text { days b.i. } \\
\text { Therapeutic: mice were } \\
\text { transplanted with } \\
\text { transduced BMCs 15-17 } \\
\text { days p.i. }\end{array}$ & i.v. & $\begin{array}{l}0.7-1.6 \times 10^{6} \text { cells per } \\
\text { mouse }\end{array}$ & $\begin{array}{l}\text { Female C57BL/6J mice (5-10 } \\
\text { weeks old) with EAE } \\
\text { induced with } \text { MOG }_{40-55}\end{array}$ & $\begin{array}{l}\text { Transplantation of BMCs expressing } \\
\text { MOG G0-55 was shown to protect }_{\text {mice from developing EAE and }} \\
\text { reduce the disease severity in mice } \\
\text { with established EAE. }\end{array}$ \\
\hline \multicolumn{7}{|c|}{ Myeloid-derived suppressor cells (MDSCs) } \\
\hline $\begin{array}{l}\text { MDSCs isolated via positive } \\
\text { selection from BMCs } \\
\text { expressing } \mathrm{MOG}_{40-55}[174]\end{array}$ & liMOG & $\begin{array}{l}\text { Prophylactic: mice were } \\
\text { transplanted with MDSCs } \\
\text { transduced with liMOG } \\
\text { seven days b.i. } \\
\text { Therapeutic: mice were } \\
\text { transplanted with } \\
\text { transduced MDSCs 13-14 } \\
\text { days p.i. }\end{array}$ & i.v. & $0.5-1 \times 10^{6}$ cells per mouse & $\begin{array}{l}\text { Female C57BL6/J mice (6-8 } \\
\text { weeks old) with EAE } \\
\text { induced with } \mathrm{MOG}_{40-55}\end{array}$ & $\begin{array}{l}\mathrm{MOG}_{40-55} \text {-expressing MDSCs were } \\
\text { found to exhibit both preventive } \\
\text { and therapeutic effects in EAE } \\
\text { induced with } \mathrm{MOG}_{40-55}\end{array}$ \\
\hline
\end{tabular}


Table 4. Cont.

\begin{tabular}{|c|c|c|c|c|c|c|}
\hline Cells & Inductive Agent/Peptide & Vaccination Type & Admin. Route & Admin. Dose & Animal Model & Vaccination Outcome \\
\hline \multicolumn{7}{|c|}{ Antigen-cell conjugates } \\
\hline Ag-SP [158] & $\begin{array}{l}\text { Chemically treated } \\
\text { Ag-coupled SPs }\end{array}$ & $\begin{array}{l}\text { Administration on day }-7 \\
\text { b.i. or at peak of disease in } \\
\text { actively induced EAE, or } \\
\text { two days p.i. }\end{array}$ & i.v. & $50 \times 10^{6} \mathrm{Ag}$-SPs per mouse & $\begin{array}{l}\text { Wild-type C57BL/6 (I-Ab), } \\
\text { B10.S (I-As), and BALB/c } \\
\text { (I-Ad) female mice (5-6 } \\
\text { weeks old) with EAE } \\
\text { induced with myelin } \\
\text { peptide or via adoptive } \\
\text { transfer. }\end{array}$ & $\begin{array}{l}\text { It was revealed that syngeneic or } \\
\text { allogeneic Ag-SPs can effectively } \\
\text { protect mice against ongoing } \\
\text { clinical EAE. }\end{array}$ \\
\hline Ag-SP [159] & $\begin{array}{l}\text { Chemically treated } \\
\text { Ag-coupled SPs }\end{array}$ & $\begin{array}{l}\text { Prophylactic: at indicated } \\
\text { time points b.i. }\end{array}$ & i.v. & $\begin{array}{l}50 \times 10^{6} \mathrm{Ag}-\mathrm{SPs} \text { or } 15-20 \\
\mu \mathrm{g} \mathrm{Ag} \text { per mouse }\end{array}$ & $\begin{array}{l}\text { SJL and C57BL/6 mice with } \\
\text { EAE induced with myelin } \\
\text { peptide or via adoptive } \\
\text { transfer. }\end{array}$ & $\begin{array}{l}\text { i.v. infusion of peptide antigens } \\
\text { coupled to syngeneic splenic } \\
\text { leukocytes (Ag-SP) was found to } \\
\text { efficiently induce antigen-specific } \mathrm{T} \\
\text { cell tolerance. }\end{array}$ \\
\hline Ag-RBC [160] & $\begin{array}{l}\text { Genetically engineerd } \\
\text { Kell-LPETGG RBCs, } \\
\text { coupled with MOG } \\
\text { through enzymatic surface } \\
\text { modification with sortase } \\
\text { transpeptidase. }\end{array}$ & $\begin{array}{l}\text { Prophylactic: transfusion } \\
\text { seven days b.i. } \\
\text { Preclinical: transfusion five } \\
\text { days p.i. } \\
\text { Therapeutic: Transfusion } \\
\text { on the day of EAE onset }\end{array}$ & i.v. & $200 \mu \mathrm{L}$ RBC-MOG $35-55$ & $\begin{array}{l}\text { C57BL/6J (CD45.2+), } \\
\text { B6.SJL-Ptprc (CD45.1+), } \\
\text { BALB/c Female C57BL/6 } \\
\text { mice (10-12 weeks old) } \\
\text { with EAE induced with } \\
\text { MOG }_{35-55}\end{array}$ & $\begin{array}{l}\text { The transfusion of RBC-MOG } 35-55 \\
\text { was shown to significantly improve } \\
\text { the clinical signs of EAE in mice. }\end{array}$ \\
\hline
\end{tabular}

BMDCs: Bone marrow-derived dendritic cells; p.i.: post immunization; i.p.: intraperitoneal; EAE: experimental allergicencephalomyelitis; tolDCs: tolerogenic dendritic cells; s.c.: clone of a multiple sclerosis patient; HSCs: hematopoietic stem cells; SIN: selfinactivating; SP: splenocytes; RBCs: red blood cells; liMOG: vector encoding the murine invariant chain (Ii) containing $\mathrm{MOG}_{40-55}$ and enhanced green fluorescent protein (EGFP). 


\subsection{Carrier-Aided Vaccination}

In recent decades, different strategies have been pursued for the development of carriers [175-179] loaded/conjugated with myelin antigens or combinations of myelin peptides and immunomodulating agents. The developed carriers have been designed to target TCR signaling pathways, as well as cytokines and co-signaling molecules, aiming to enhance TCR-mediated tolerance $[30,62,177]$. Various biomaterials (e.g., polymers, lipids) have been formulated into micro- or nanoparticles, self-assembled into different structures, or formed molecular conjugates with self-antigens (e.g., conjugation of self-antigens with polymers, antibodies, small molecules). Both nanoparticles (NPs) and microparticles (MPs) can be uptaken by APCs thus enhancing the intracellular delivery of myelin antigens and imunnomodulators [180,181].

\subsubsection{Polymer Particles}

Polymer micro- and nanoparticles loaded with self-antigens and/or immunomodulatory molecules have recently emerged as ideal carriers for tolerogenic vaccines since their properties (e.g., particle size, composition, antigen/immunomodulator loading) can be fine-tuned to induce peripheral tolerance. Furthermore, NPs can be employed as platforms to regulate the doses and delivery times not only of the self-antigens but also of the tolerogenic adjuvants that are required to promote tolerance [70].

Poly(lactic-co-glycolic acid) (PLGA) NPs are non-toxic, biodegradable/biocompatible and have the advantage of being FDA approved for various clinical uses including drug delivery, diagnostics, etc. Additionally, surface functionalization strategies may improve their interaction with cells, thus optimizing cell targeting and vaccine performance. PLGA NPs are the most extensively assessed nanocarriers in pre-clinical models of autoimmune diseases and their effectiveness regarding antigen-specific immunotherapies (Table 5) represents a proof-of-concept of the feasibility of nanoparticle-aided tolerogenic vaccination. Furthermore, their successful application in animal models appears encouraging concerning potential translation to humans [70].

\subsubsection{Soluble Antigen Arrays}

Soluble antigen arrays (SAgAs) are synthesized by co-grafting the immunodominant epitope PLP $139-151$ and LABL peptide (i.e., ligand of the intercellular adhesion molecule 1, ICAM-1) to hyaluronic acid (HA) via a hydrolysable oxime bond [182,183]. Their size can be fine-tuned to allow them to drain to the lymph nodes [183]. Another key factor affecting their drainage is the injection site and the molecular weight of HA. For example, following s.c. injection, HA can drain to the lymphatics and its retention time can be affected by its molecular weight [183].

The efficiency of the hydrolysable SAgAPLP-LABL to suppress disease in mice with EAE has been reported in various studies (Table 5) and has been attributed to the simultaneous delivery of the myelin derived antigen and the cell adhesion signal [182]. Furthermore, earlier in vitro studies indicated that SAgAs demonstrate Ag-specific binding with B lymphocytes, target the B cell receptor (BCR) and reduce $B C R$-mediated signaling [184]. Based on the abovementioned experimental results indicating BCR engagement as the mechanism of action of SAgAPLP-LABL Hartwell and coworkers developed a novel version of SAgA PLP-LABL, the CSAgAPLP:LABL (click SAgA), employing non-hydrolysable conjugation chemistry (e.g., copper-catalyzed azide-alkyne aycloaddition) $[184,185]$. cSAgAPLP:LABL was found to significantly reduce or inhibit BCR-mediated signaling and to exhibit enhanced in vivo efficiency in comparison with the hydrolytically unstable SAgAPLP-LABL $[184,185]$ (Figure 11). 

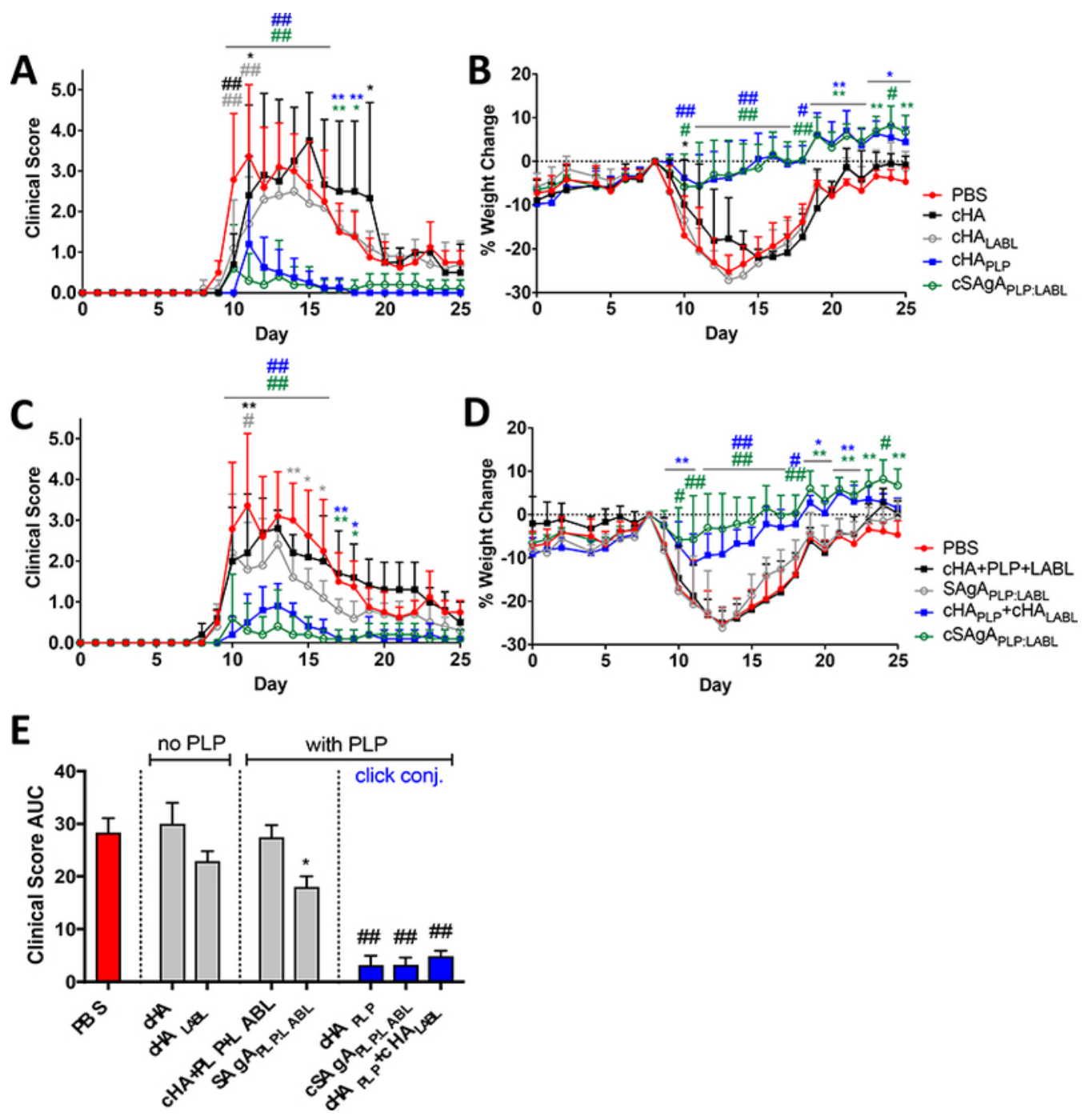

Figure 11. EAE in vivo response to click conjugates (cHA, cHALabl, cHAPLP, and cSAgAPLP:LABL) as measured by (A) clinical disease score and (B) percent weight loss. EAE in vivo response to groups containing both PLP and LABL (cHA+PLP+LABL, SAgAPLP:LABL, cHAPLP+cHALABL, and cSAgAPLP:LABL) as measured by $(\mathbf{C})$ clinical disease score and (D) percent weight loss. Data represent mean $\pm \mathrm{SD}(n=5)$; statistical significance compared to PBS negative control was determined by two-way ANOVA. (E) Cumulative EAE in vivo response as measured by clinical disease score area under the curve (AUC) derived from subfigures A and C. Data represent mean $\pm \operatorname{SEM}(n=5)$; statistical significance compared to PBS negative control was determined by ordinary one-way ANOVA followed by Dunnett's post hoc test. $\left({ }^{*} p<0.05,{ }^{* *} p<0.01\right.$, \# $p<0.001$, \#\# $p<0.0001$, color coded according to group) (with permission of [185]).

\subsubsection{Immune Polyelectrolyte Multilayers (iPEMs)}

It has been recently shown that excess signaling via inflammatory pathways such as toll-like receptors (TLRs) is involved in the pathogenesis of autoimmune diseases. Accordingly, the co-delivery of immunodominant myelin peptides with GpG oligonucleotide, a regulatory ligand of TLR9, could potentially limit TLR signaling during the differentiation of myelin-specific T lymphocytes, thus redirecting their differentiation towards a tolerogenic phenotype like the regulatory $\mathrm{T}$ cells. In this respect, immune polyelectrolyte multilayers (iPEMs) were formed using a layer-by-layer approach to co-assemble modified myelin peptides with GpG oligonucleotide. These nanostructures have key characteristics of biomaterial-based nanocarriers, such as tunable physicochemical properties 
and loading capacity, ability to deliver various active ingredients, etc., lacking, however, synthetic components that could exhibit inflammatory properties.

In in vitro studies, iPEMs have been shown to limit TLR9 signaling, decrease activation of DCs, and polarize myelin-specific T lymphocytes towards a tolerogenic phenotype. Additionally, they have been found to reduce inflammation and induce tolerance in mice with EAE $[186,187]$ (Table 5).

\subsection{4. pMHC-Nanoparticles (pMHC-NPs)}

The "two signal theory" states that two different signals are required for the activation of naive $\mathrm{T}$ cells: (i) engagement of the TCR with its cognate pMHC target, and (ii) a co-stimulatory signal from molecules selectively expressed on professional APCs' surface. It is well known that engagement of the TCR on the surface of a naive T cell without co-stimulation results in the induction of apoptosis or anergy.

The development of pMHC-nanoparticles (pMHC-NPs) for the treatment of autoimmune diseases was based on the hypothesis that pMHC-coated NPs would diminish the responses of autoreactive T cells more efficiently compared with soluble pMHC complexes. This could be due to (i) their multimeric valency, (ii) their potentially superior TCR cross-linking properties compared with "artificial APCs", and (iii) the protection of the NP-bound pMHC molecules from degradation [104]. The ability of pMHC-NPs to stop the progression of EAE was assessed with in vivo experiments in mice (Table 5).

\subsubsection{Mannan-Peptide Conjugates}

Based on previous studies with the yeast polysaccharide, mannan, Tseveleki and coworkers, examined mannan conjugation with immunodominant myelin epitopes as an approach to divert the differentiation of myelin-specific $\mathrm{T}$ lymphocytes towards a regulatory phenotype, thus decreasing the mice susceptibility to EAE. It was shown that the administration of the synthesized conjugates to mice in both prophylactic and therapeutic vaccination protocols resulted in the induction of antigen-specific $\mathrm{T}$ cell tolerance and significant amelioration of EAE clinical and histopathological symptoms. [188] (Figure 12) (Table 5). According to these results, it was speculated that conjugation of MOG epitopes to mannan may modulate the autoimmune response in humans, thus potentially reducing the symptoms of MS [188].

\subsubsection{Liposomes}

Liposomes are tiny vesicles featuring an aqueous core surrounded by a lipid bilayer. They can encapsulate both hydrophilic and hydrophobic drugs and target them to specific cell surfaces via appropriate functionalization. Various types of liposomes have been already approved for clinical use (e.g., delivery of therapeutics, vaccination) and can be designed to induce or tolerate immune responses [189]. Pujol-Autonell and coworkers reported the beneficial effect of MOG peptide loaded liposomes in treating mice with EAE. Liposomes successfully delayed the onset, suppressed the severity and decreased the incidence of the disease [190]. Similarly, Belogurov and co-workers demonstrated that mannosylated liposomes containing $\mathrm{MBP}_{46-62}$ could significantly reduce EAE clinical signs in Dark Agouti (DA) rats [189]. Interestingly liposomes loaded with $\mathrm{MBP}_{46-62}, \mathrm{MBP}_{124-139}$, and $\mathrm{MBP}_{147-170}$ and targeting CD206 were proven to be safe and well-tolerated and to normalize cytokine levels in RRMS and SPMS patients [191,192].

\subsubsection{Microneedle Patches}

Pires and coworkers proposed the use of minimally invasive microneedle patches for the delivery of myelin peptides, as an alternative therapeutic strategy for skin mediated antigen-specific immune tolerance in MS [178]. 

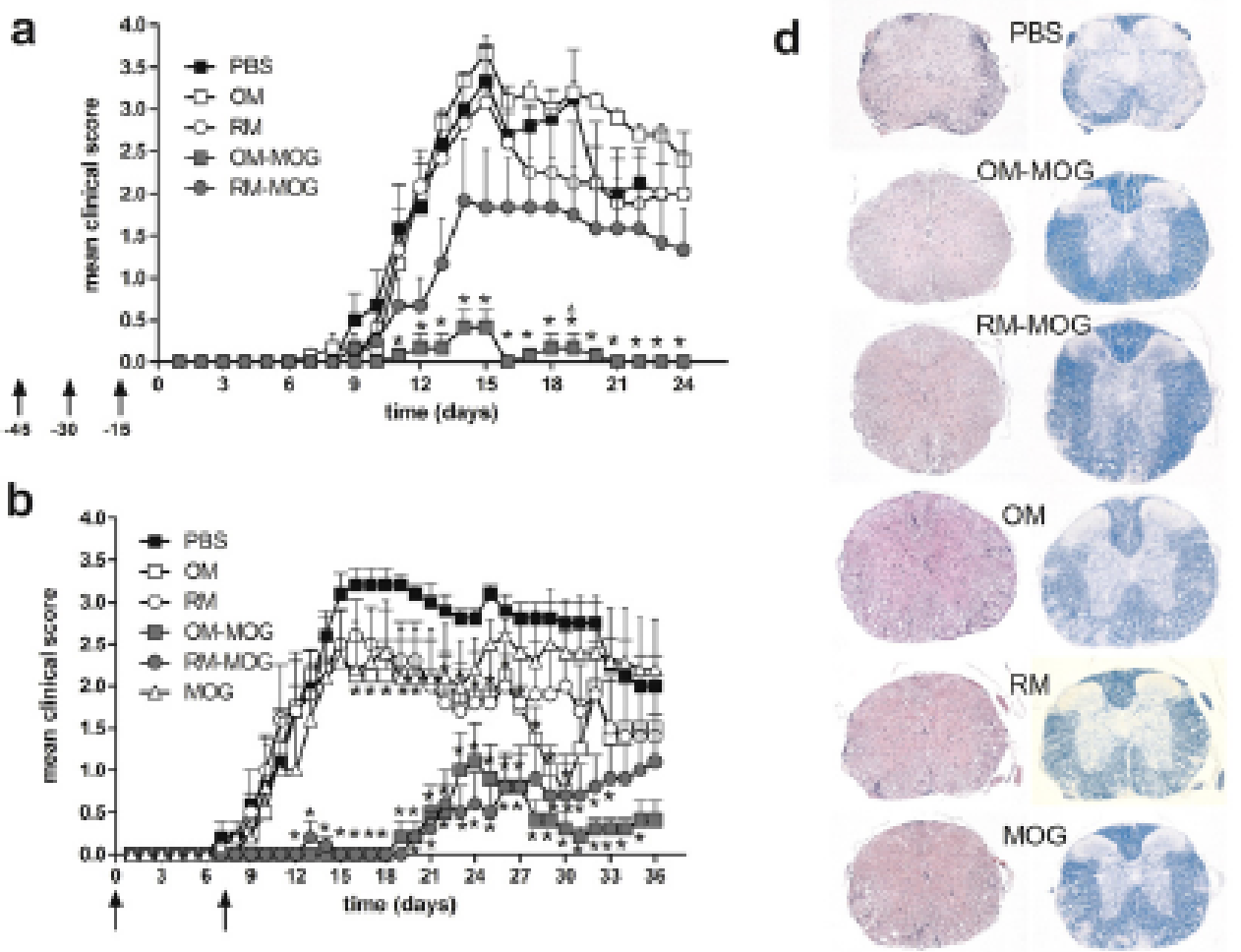

e
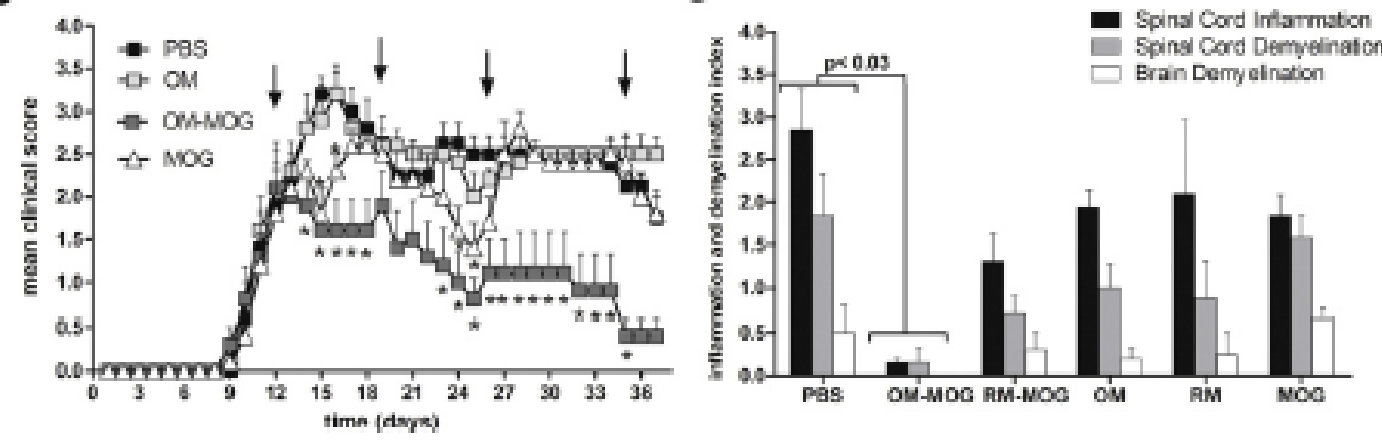

Figure 12. (a) Mean clinical scores of MOG-EAE in groups of mice vaccinated i.d. with OM-MOG, RM-MOG, OM, RM, or PBS at indicated time points (arrows) before immunization for EAE induction. (b) Mean clinical scores of MOG-EAE in groups of mice vaccinated i.d. at indicated time points (arrows) relative to immunization. (c) Mean clinical scores of MOG-EAE in groups of mice injected i.d. at indicated time points (arrows) after immunization. The results shown are from one representative of two $(\mathbf{b}, \mathbf{c})$ or three (a) independent experiments. (d,e) Vaccination with OM-MOG protects C57BL/6 mice from spinal cord inflammation and demyelination during MOG-EAE. (d) Inflammatory cell infiltration (left column) and demyelination (right column) were visualized on day 24 following immunization. (e) Quantification of spinal cord inflammation (black bars) and demyelination (grey bars) as well as brain demyelination (white bars) in all experimental groups. Representative data from five animals per group are shown. Statistical significance after comparisons between groups of mice (using the Kruskal-Wallis test) or histopathology indices (using Student's $t$ test) is shown $\left({ }^{*}, p<0.05\right)$. Triangles (a) indicate time points where pair-wise comparison between OM-MOG and RM-MOG groups also show significant differences (with permission of [188]). 
Table 5. Carrier-aided vaccination.

\begin{tabular}{|c|c|c|c|c|c|c|c|c|c|c|}
\hline Carrier & $\begin{array}{l}\text { Particle Size } \\
(\mathrm{nm})\end{array}$ & $\begin{array}{l}\text { Zeta Potential } \\
(\mathrm{mV})\end{array}$ & Antigen & $\begin{array}{l}\text { Ag Loading } \\
\text { (wt \%)/Enc. Eff. (\%) }\end{array}$ & $\begin{array}{l}\text { Immunomodul. } \\
\text { Agent }\end{array}$ & Vaccination Type & Admin. Route & Dose & Animal Model & Vaccination Outcome \\
\hline \multicolumn{11}{|l|}{ Polymer particles } \\
\hline PLGA NPs [193] & - & - & $\mathrm{MOG}_{35-55}$ & - & (r) IL-10 & $\begin{array}{l}\text { Prophylactic: } 31 \text { and } \\
15 \text { days b.i. } \\
\text { Therapeutic: eight } \\
\text { and } 22 \text { days p.i. }\end{array}$ & s.c. & & $\begin{array}{l}\text { Female C57BL/6 } \\
\text { mice with EAE } \\
\text { induced with } \\
\text { MOG }_{35-55}\end{array}$ & $\begin{array}{l}\text { Vaccination with } \\
\text { mixed PLGA- } \\
\text { MOG } 35-55 \text { and } \\
\text { PLGA-IL10 both in a } \\
\text { prophylactic and } \\
\text { therapeutic setting } \\
\text { resulted in significant } \\
\text { protection, decrease } \\
\text { of EAE severity and } \\
\text { reduction of } \\
\text { histopathological } \\
\text { lesions in spinal cord. } \\
\text { i.v. vaccination with }\end{array}$ \\
\hline PLGA NPs [194] & - & - & $\operatorname{PLP}_{139-151}$ & $8 \mu \mathrm{g} / \mathrm{mg} N P$ & $\begin{array}{l}\text { TGF- } \beta \\
(166 \mathrm{ng} / \mathrm{mg} \mathrm{NP})\end{array}$ & $\begin{array}{l}\text { Prophylactic: seven } \\
\text { days b.i. } \\
\text { Therapeutic: } \\
13 \text { days p.i. }\end{array}$ & $\begin{array}{l}\text { i.v. } \\
\text { s.c. }\end{array}$ & $\begin{array}{l}2.5,1.25,0.0625 \\
\text { mg NPs }\end{array}$ & $\begin{array}{l}\text { Female SJL/J } \\
\text { mice (6-8 weeks } \\
\text { old) with EAE } \\
\text { induced with } \\
\text { PLP }_{139-151}\end{array}$ & 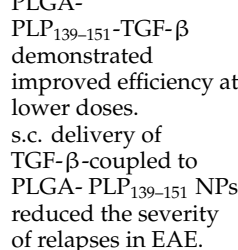 \\
\hline $\begin{array}{l}\text { PLGA } \\
\text { MPs [195] }\end{array}$ & $800,55,000$ & & $\mathrm{MOG}_{35-55}$ & $-/ 48.6$ & $\begin{array}{l}\text { Vitamin D3 } \\
\text { TGF- } \beta 1 \\
\text { Recombinant } \\
\text { mouse GM-CSF }\end{array}$ & $\begin{array}{l}\text { Preclinical/Therapeutic: } \\
4,7 \text {, and } 10 \text {, days p.i. }\end{array}$ & s.c. & & $\begin{array}{l}\text { Female C57BL/6 } \\
\text { mice (10-11 } \\
\text { weeks old) with } \\
\text { EAE induced } \\
\text { with } \text { MOG }_{35-55}\end{array}$ & $\begin{array}{l}\text { Delivery of various } \\
\text { immunomodulators } \\
\text { combined with } \\
\text { MOG }_{35-55} \text { via a dual } \\
\text { size MP platform } \\
\text { resulted in the } \\
\text { induction of enhanced } \\
\text { antigen-specific } \\
\text { autoimmune } \\
\text { protection }\end{array}$ \\
\hline PLGA NPs [196] & $151.2,521.7$ & $-14.1,-5.65$ & $\mathrm{MOG}_{35-55}$ & $\begin{array}{l}2.58,0.96 / 25.85, \\
9.65\end{array}$ & - & $\begin{array}{l}\text { Prophylactic: seven } \\
\text { days b.i. }\end{array}$ & $\begin{array}{l}\text { i.v. } \\
\text { s.c. }\end{array}$ & 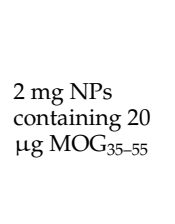 & $\begin{array}{l}\text { Female C57BL/6 } \\
\text { mice (6-8 weeks } \\
\text { old) with EAE } \\
\text { induced with } \\
\text { MOG }_{35-55}\end{array}$ & $\begin{array}{l}\text { The intravenous } \\
\text { injection of PLGA- } \\
\text { MOG }_{35-55} \text { was shown } \\
\text { to delay EAE } \\
\text { incidence and } \\
\text { enhance } \\
\text { antigen-specific } \\
\text { immune tolerance. }\end{array}$ \\
\hline
\end{tabular}


Table 5. Cont

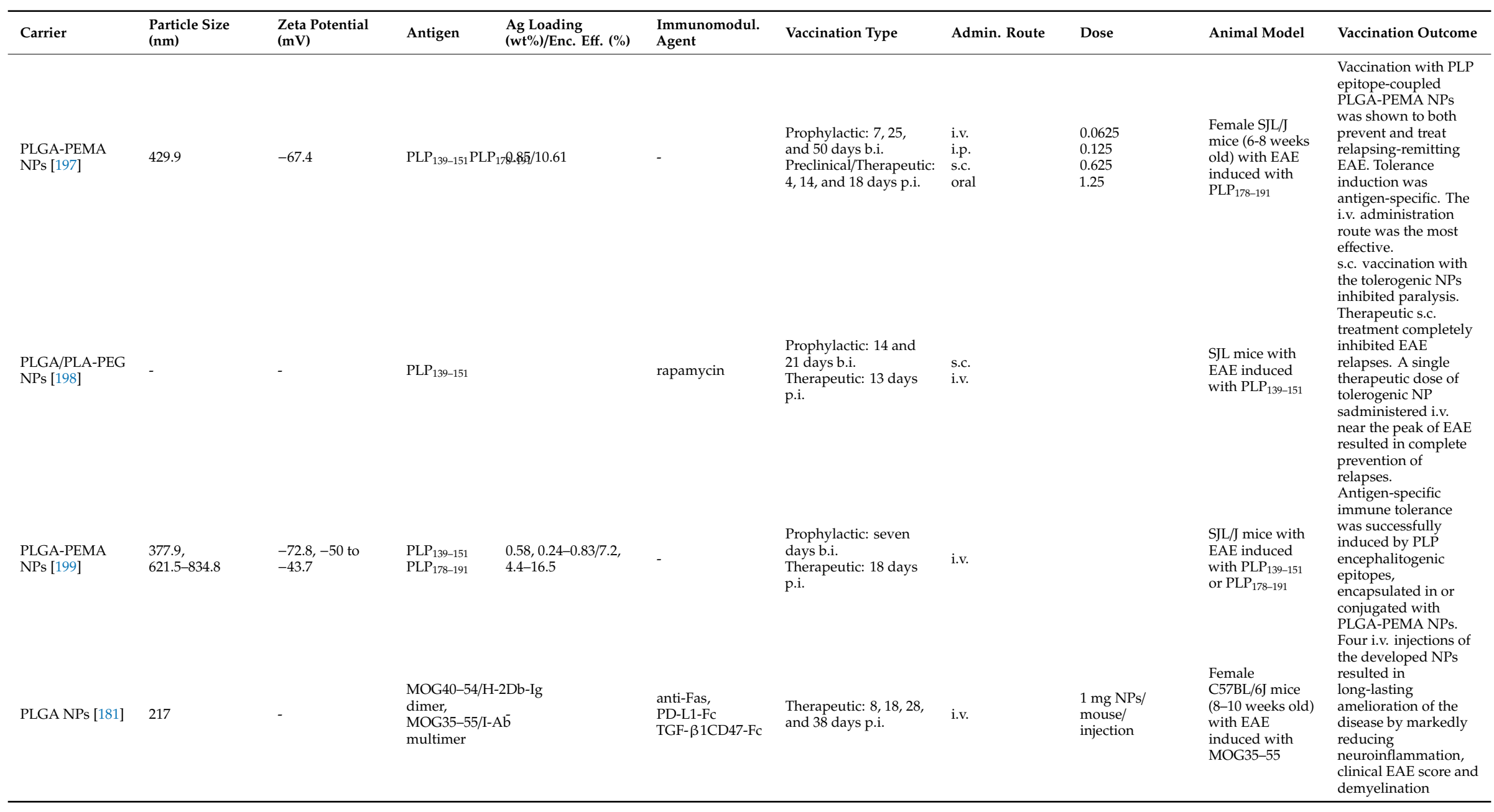


Table 5. Cont

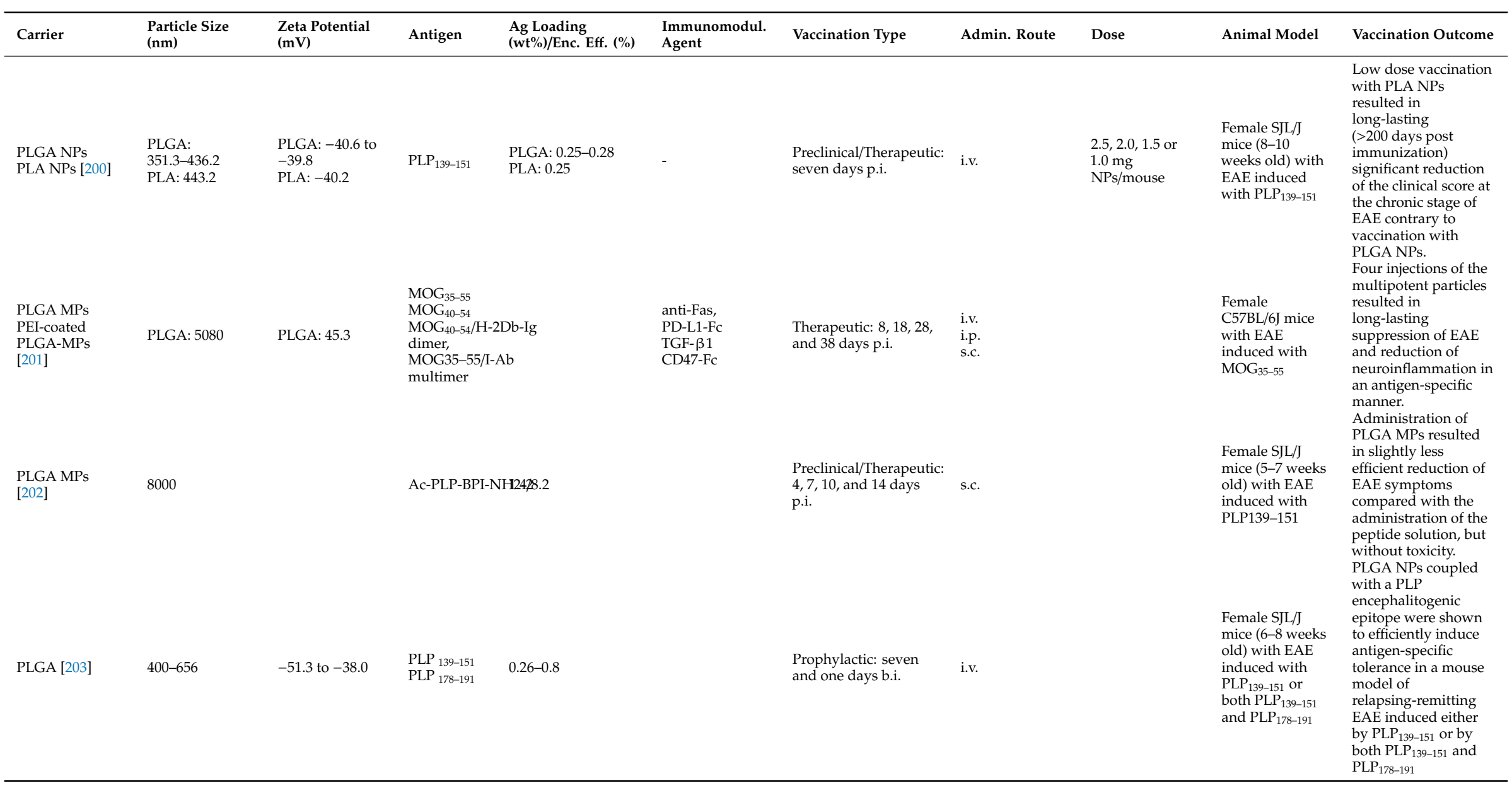


Table 5. Cont.

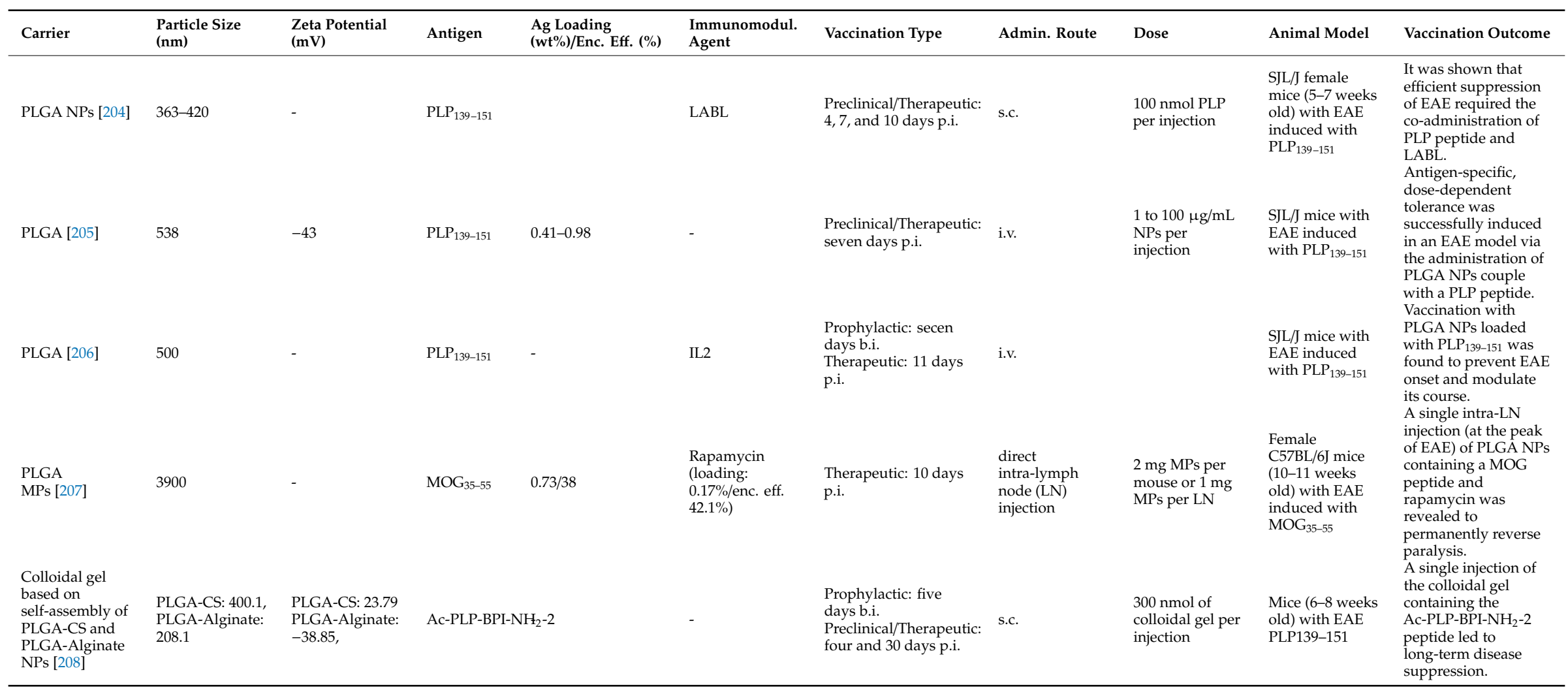


Table 5. Cont.

\begin{tabular}{|c|c|c|c|c|c|c|c|c|c|c|}
\hline Carrier & $\begin{array}{l}\text { Particle Size } \\
(\mathrm{nm})\end{array}$ & $\begin{array}{l}\text { Zeta Potential } \\
(\mathrm{mV})\end{array}$ & Antigen & $\begin{array}{l}\text { Ag Loading } \\
(\mathbf{w t} \%) / \text { Enc. Eff. (\%) }\end{array}$ & $\begin{array}{l}\text { Immunomodul. } \\
\text { Agent }\end{array}$ & Vaccination Type & Admin. Route & Dose & Animal Model & Vaccination Outcome \\
\hline \multicolumn{11}{|c|}{ Soluble antigen arrays (SAgAs) } \\
\hline $\begin{array}{l}\text { HA-peptide } \\
\text { conjugate [209] }\end{array}$ & $\mathrm{HA}$ & - & $\mathrm{PLP}_{139-151}$ & - & $\begin{array}{l}\text { LABL, B7AP, } \\
\text { CD80-CAP1, } \\
\text { sF2 (cyclized) }\end{array}$ & $\begin{array}{l}\text { Preclinical/Therapeutic: } \\
4,7 \text {, and } 10 \text { days p.i. }\end{array}$ & s.c. & $\begin{array}{l}200 \text { nmol PLP } \\
\text { peptide }\end{array}$ & $\begin{array}{l}\mathrm{SJL} / \mathrm{J}(\mathrm{H}-2 \mathrm{~s}) \\
\text { female mice } \\
\text { (4-6 weeks old }) \\
\text { with EAE } \\
\text { induced with } \\
\text { PLP }_{139-151}\end{array}$ & $\begin{array}{l}\text { SAgAs were shown to } \\
\text { effectively reduce } \\
\text { EAE incidence and } \\
\text { suppress it via } \\
\text { co-administration of } \\
\text { an immunodominant } \\
\text { myelin epitope and } \\
\text { peptides targeting the } \\
\text { B7 signaling pathway }\end{array}$ \\
\hline SAgAs [210] & $\mathrm{HA}$ & - & PLP $_{139-151}$ & - & LABL & $\begin{array}{l}\text { Preclinical/Therapeutic: } \\
4,7 \text {, and } 10 \text { days p.i. }\end{array}$ & s.c. & $\begin{array}{l}200 \mathrm{nmol} \\
\mathrm{PLP}_{139-151}\end{array}$ & $\begin{array}{l}\text { SJL/J female } \\
\text { mice (4-6 weeks } \\
\text { old) with EAE } \\
\text { induced with } \\
\text { PLP }_{139-151}\end{array}$ & $\begin{array}{l}\text { Co-administration via } \\
\text { conjugation of } \\
\text { PLPP P139-151 and LABL } \\
\text { improved the clinical } \\
\text { scores of EAE }\end{array}$ \\
\hline cSAgAs [184] & HA & - & PLP $_{139-151}$ & & LABL & $\begin{array}{l}\text { Preclinical/Therapeutic: } \\
4,7 \text {, and } 10 \text { days p.i. }\end{array}$ & s.c. & $\begin{array}{l}\text { 50, 133, or } 200 \\
\text { nmol PLP }\end{array}$ & $\begin{array}{l}\text { SJL/J female } \\
\text { mice (4-6 weeks } \\
\text { old) with EAE } \\
\text { induced with } \\
\text { PLP }_{139-151}\end{array}$ & $\begin{array}{l}\text { CSAgAs was found to } \\
\text { achieve equivalent } \\
\text { efficiency with } \\
\text { SAgAS regarding the } \\
\text { suppression of EAE at } \\
\text { a quarter of the } \\
\text { SAgAS dose. } \\
\text { Low dose s.c. }\end{array}$ \\
\hline $\begin{array}{l}\text { cSAgAs } \\
\text { (Figure 11) [185] }\end{array}$ & $\mathrm{HA}$ & - & $\mathrm{PLP}_{139-151}$ & - & LABL & $\begin{array}{l}\text { Preclinical/Therapeutic: } \\
4,7 \text {, and } 10 \text { days p.i. }\end{array}$ & s.c. & $\begin{array}{l}\text { 50, nmol } \\
\text { PLP }_{139-151}\end{array}$ & $\begin{array}{l}\text { SJL/J female } \\
\text { mice (4-6 weeks } \\
\text { old) with EAE } \\
\text { induced with } \\
\text { PLP }_{139-151}\end{array}$ & $\begin{array}{l}\text { vaccination with } \\
\text { cSAgAS resulted in } \\
\text { successful } \\
\text { suppression of EAE } \\
\text { clinical symproms } \\
\text { and minimization of } \\
\text { body weight loss. }\end{array}$ \\
\hline SAgAs [210] & $\mathrm{HA}$ & - & $\mathrm{PLP}_{139-151}$ & - & LABL & $\begin{array}{l}\text { Preclinical/Therapeutic: } \\
4,7 \text {, and } 10 \text { days p.i. }\end{array}$ & pulmonary & $\begin{array}{l}65.1-74.5 \mathrm{mg} \\
\text { SAgAs/mouse } \\
\mathrm{kg}\end{array}$ & $\begin{array}{l}\text { Female SJL/J } \\
\text { mice (four } \\
\text { weeks old) with } \\
\text { EAE induced } \\
\text { with PLP P139-151 }\end{array}$ & $\begin{array}{l}\text { The pulmonary } \\
\text { administration of } \\
\text { SAgAs was found to } \\
\text { suppress the clinical } \\
\text { score of the disease, } \\
\text { decrease EAE } \\
\text { incidence and } \\
\text { improve weight gain. }\end{array}$ \\
\hline
\end{tabular}


Table 5. Cont.

\begin{tabular}{|c|c|c|c|c|c|c|c|c|c|c|}
\hline Carrier & $\begin{array}{l}\text { Particle Size } \\
\text { (nm) }\end{array}$ & $\begin{array}{l}\text { Zeta Potential } \\
(\mathrm{mV})\end{array}$ & Antigen & $\begin{array}{l}\text { Ag Loading } \\
(\mathbf{w t} \%) / \text { Enc. Eff. (\%) }\end{array}$ & $\begin{array}{l}\text { Immunomodul. } \\
\text { Agent }\end{array}$ & Vaccination Type & Admin. Route & Dose & Animal Model & Vaccination Outcome \\
\hline SAgAs [183] & $\mathrm{HA}$ & - & PLP $_{139-151}$ & - & LABL & $\begin{array}{l}\text { Preclinical/Therapeutic: } \\
4,7 \text {, or } 10 \text { days p.i. }\end{array}$ & $\begin{array}{l}\text { i.p., upper and } \\
\text { lower i.m., } \\
\text { upper and } \\
\text { lower s.c., i.v. } \\
\text { pulmonary }\end{array}$ & $\begin{array}{l}200 \mathrm{nMol} \text { PLP } \\
\text { per } 100 \mu \mathrm{L} \\
\text { injection } \\
\text { volume } 200 \\
\text { nMol PLP per } \\
50 \mu \mathrm{L} \text { injection } \\
\text { volume }\end{array}$ & $\begin{array}{l}\text { Female SJL/J } \\
\text { mice (6-8 weeks } \\
\text { old) with EAE } \\
\text { induced with } \\
\text { PLP }_{139-151}\end{array}$ & $\begin{array}{l}\text { i.v. administration } \\
\text { demonstrated similar } \\
\text { efficiency with the } \\
\text { other routes. p.i. } \\
\text { vaccination decreased } \\
\text { completely clinical } \\
\text { disease scores. Single } \\
\text { injection-based } \\
\text { treatment resulted in } \\
\text { decreased efficiency } \\
\text { compared with a } \\
\text { triple injection } \\
\text { treatment. Decrease } \\
\text { of SAgAs dose and/or } \\
\text { injection volume } \\
\text { decreased the } \\
\text { therapeutic efficiency. }\end{array}$ \\
\hline \multicolumn{11}{|c|}{ Immune polyelectrolyte multilayers (iPEMs) } \\
\hline iPEMs [186] & - & - & MOG-R3 & $28.4-89.7 \%$ & $\begin{array}{l}\text { GpG } \\
(0.7-10.3 \%)\end{array}$ & $\begin{array}{l}\text { Preclinical/Therapeutic: } \\
5 \text { and } 10 \text { p.i. }\end{array}$ & s.c. & $\begin{array}{l}200 \mu \mathrm{g} \text { of } \\
\text { (MOG-R3/GpG)3 } \\
\text { iPEMs, per } \\
\text { injection. }\end{array}$ & $\begin{array}{l}\text { C57BL/6J mice } \\
\text { with EAE } \\
\text { induced with a } \\
\text { myelin antigen }\end{array}$ & $\begin{array}{l}\text { s.c. delivery of iPEMs } \\
\text { restrained } \\
\text { inflammation and } \\
\text { promoted } \\
\text { autoimmune } \\
\text { tolerance in an EAE } \\
\text { mouse models. }\end{array}$ \\
\hline iPEMs [187] & 114.9-199.2 & -42.5 to 33.4 & $\begin{array}{l}\text { MOGR1, } \\
\text { MOGR2 }\end{array}$ & $\begin{array}{l}0.57-9.18 \mu \mathrm{g} \text { of } \\
\text { MOGRx }\end{array}$ & $\begin{array}{l}\text { GpG } 2.18 \\
\mu \mathrm{g}-4.88 \mu \mathrm{g}\end{array}$ & $\begin{array}{l}\text { Preclinical/Therapeutic: } \\
\text { seven days or } 6,12, \\
\text { and } 18 \text { days p.i. }\end{array}$ & s.c. & $\begin{array}{l}200 \mu \mathrm{g} \text { MOGR2 } \\
(85.9 \mu \mathrm{g} \mathrm{GpG})\end{array}$ & $\begin{array}{l}\text { Female } \\
\text { C57BL/6J mice } \\
\text { (10 weeks old) } \\
\text { with EAE } \\
\text { induced with } \\
\text { MOG }_{35-55}\end{array}$ & $\begin{array}{l}\text { iPEMs were shown to } \\
\text { improve the severity, } \\
\text { progression and } \\
\text { incidence of EAE. }\end{array}$ \\
\hline \multicolumn{11}{|c|}{ Inorganic particles and pMHC-nanoparticles (pMHC-NPs) } \\
\hline $\begin{array}{l}\text { Quantum } \\
\text { dots [211] }\end{array}$ & $15.0-21.0$ & -17.6 to -4.2 & MOG & Up to 55 & - & $\begin{array}{l}\text { Preclinical: two days } \\
\text { p.i. }\end{array}$ & s.c. & & $\begin{array}{l}\text { Female C57BL/6 } \\
\text { mice (10-12 } \\
\text { weeks old })\end{array}$ & $\begin{array}{l}\text { Ten-fold reduction of } \\
\text { EAE incidence. } \\
\text { Increased numbers of } \\
\text { QDs with lower } \\
\text { peptide loading were } \\
\text { more efficient } \\
\text { regarding the } \\
\text { induction of immune } \\
\text { tolerance. }\end{array}$ \\
\hline
\end{tabular}


Table 5. Cont

\begin{tabular}{|c|c|c|c|c|c|c|c|c|c|c|}
\hline Carrier & $\begin{array}{l}\text { Particle Size } \\
(\mathrm{nm})\end{array}$ & $\begin{array}{l}\text { Zeta Potential } \\
(\mathrm{mV})\end{array}$ & Antigen & $\begin{array}{l}\text { Ag Loading } \\
(\mathbf{w t} \%) / \text { Enc. Eff. }(\%)\end{array}$ & $\begin{array}{l}\text { Immunomodul. } \\
\text { Agent }\end{array}$ & Vaccination Type & Admin. Route & Dose & Animal Model & Vaccination Outcome \\
\hline $\begin{array}{l}\text { Iron oxide } \\
\text { NPs [212] }\end{array}$ & - & - & $\mathrm{MOG}_{38-49}$ & - & $\mathrm{IA}^{\mathrm{b}}$ & $\begin{array}{l}\text { Therapeutic: } 14 \text { or } 21 \\
\text { days p.i. }\end{array}$ & & & $\begin{array}{l}\text { C57BL/6 mice } \\
\text { with EAE } \\
\text { induced with } \\
\text { pMOG } \\
\text { MS-55 }\end{array}$ & $\begin{array}{l}\text { By administration on } \\
\text { day } 14 \text { the NPs were } \\
\text { found to diminish the } \\
\text { progression of the } \\
\text { disease, whereas } \\
\text { when administered } \\
\text { on day } 21 \text { they were } \\
\text { shown to restore the } \\
\text { motor function of } \\
\text { paralytic mice. }\end{array}$ \\
\hline $\begin{array}{l}\text { Iron oxide } \\
\text { NPs [212] }\end{array}$ & - & - & $\begin{array}{l}\text { hPLP }_{175-192} \\
\text { hMOG }_{97-108}\end{array}$ & - & DR4-IE & Therapeutic: & & & $\begin{array}{l}\text { HLA-DR4-IE- } \\
\text { transgenic } \\
\text { C57BL/6 IAbnull } \\
\text { mice }\end{array}$ & $\begin{array}{l}\text { Successful EAE } \\
\text { suppression was } \\
\text { observed. }\end{array}$ \\
\hline $\begin{array}{l}\text { Pegylated gold } \\
\text { NPs [213] }\end{array}$ & 60 & - & $\begin{array}{l}\text { MOG }_{35-55} \\
\text { PLP }_{139-151} \\
\text { PLP }_{178-191}\end{array}$ & & AhR ligand ITE & $\begin{array}{l}\text { Prophylactic: admin. } \\
\text { on the day of EAE } \\
\text { induction } \\
\text { Therapeutic: Admin. } \\
\text { on day } 17 \text { post } \\
\text { immunization. } \\
\text { Weekly treatment of } \\
\text { mice }\end{array}$ & parenteral & $\begin{array}{l}6 \mu \mathrm{g} \text { NPs per } \\
\text { mouse }\end{array}$ & $\begin{array}{l}\text { B6 mice with } \\
\text { EAE induced } \\
\text { with MOG } \text { MS5-55 } \\
\text { SJL mice with } \\
\text { EAE induced } \\
\text { with EAE } \\
\text { induced with } \\
\text { PLP } 139-151\end{array}$ & $\begin{array}{l}\text { Pegylated gold NPs } \\
\text { loaded with } \\
\text { MOG35-55 and ITE } \\
\text { significantly } \\
\text { suppressed the } \\
\text { development of EAE, } \\
\text { whereas those loaded } \\
\text { with PLP epitopes } \\
\text { reduced the clinical } \\
\text { scores of the disease } \\
\text { and the number of } \\
\text { relapses. }\end{array}$ \\
\hline \multicolumn{11}{|c|}{ Mannan-conjugated myelin peptides } \\
\hline $\begin{array}{l}\text { Mannan-peptide } \\
\text { conjugates } \\
\text { (Figure 12) [188] }\end{array}$ & - & - & $\begin{array}{l}\text { MOG }_{35-55} \\
\text { PLP }_{139-151} \\
\text { PLP }_{178-191} \\
\text { MBP }_{83-99}\end{array}$ & - & - & $\begin{array}{l}\text { Prophylactic: } 45,30, \\
\text { and } 15 \text { days b.i. } \\
\text { Preclinical/Therapeutic: } \\
\text { Admin. on day } 0 \text { and } \\
7 \text { p.i. }\end{array}$ & i.d. & $\begin{array}{l}30 \mu \mathrm{g} \\
\text { peptide/injection } \\
700 \mu \mathrm{g} \\
\text { mannan/injection }\end{array}$ & $\begin{array}{l}\text { C57BL/6 mice } \\
\text { (12-14 weeks } \\
\text { old) with EAE } \\
\text { induced with } \\
\text { MOG Female } \\
\text { SJL// mice (6-8 } \\
\text { weeks old) with } \\
\text { EAE induced } \\
\text { with PLP. }\end{array}$ & $\begin{array}{l}\text { Mannan-peptide } \\
\text { conjugates were } \\
\text { shown to generate } \\
\text { robust } \\
\text { antigen-specific } \\
\text { protection of mice } \\
\text { from the clinical } \\
\text { disease symptoms. }\end{array}$ \\
\hline $\begin{array}{l}\text { Mannan-peptide } \\
\text { conjugates [214] }\end{array}$ & - & - & $\begin{array}{l}\text { Linear and } \\
\text { cyclic } \\
\text { MBP } 83-99 \\
\text { peptide } \\
\text { analogues } \\
\text { cyclo(83-99) } \\
\text { [A91]MBP83-99 } \\
\text { mutant } \\
\text { peptide }\end{array}$ & & & $\begin{array}{l}\text { Preclinical/Therapeutic: } \\
\text { Admin. on day } 0 \text { and } \\
14 \text { p.i. }\end{array}$ & i.d. & $\begin{array}{l}50 \mu \mathrm{g} \text { of linear } \\
\text { and cyclic } \\
\mathrm{MBP}_{83-99} \\
\text { peptide } \\
\text { analogues }\end{array}$ & $\begin{array}{l}\text { Female SJL/J } \\
\text { mice (6-8 weeks } \\
\text { old) with EAE } \\
\text { induced with } \\
\text { linear and cyclic } \\
\text { MBP } 83-99 \\
\text { peptide } \\
\text { analogues }\end{array}$ & $\begin{array}{l}\text { It was shown that the } \\
\text { mutant peptide } \\
\text { cyclo(83-99)[A91] } \\
\text { MBP } 83-99 \text { more } \\
\text { efficiently inhibited } \\
\text { EAE development. }\end{array}$ \\
\hline
\end{tabular}


Table 5. Cont

\begin{tabular}{|c|c|c|c|c|c|c|c|c|c|c|}
\hline Carrier & $\begin{array}{l}\text { Particle Size } \\
(\mathrm{nm})\end{array}$ & $\begin{array}{l}\text { Zeta Potential } \\
(\mathrm{mV})\end{array}$ & Antigen & $\begin{array}{l}\text { Ag Loading } \\
\text { (wt } \%) / \text { Enc. Eff. (\%) }\end{array}$ & $\begin{array}{l}\text { Immunomodul. } \\
\text { Agent }\end{array}$ & Vaccination Type & Admin. Route & Dose & Animal Model & Vaccination Outcome \\
\hline \multicolumn{11}{|l|}{ Liposomes } \\
\hline Liposomes [190] & 861.3 & -36.2 & $\mathrm{MOG}_{40-55}$ & -191.5 & - & $\begin{array}{l}\text { Preclinical/Therapeutic: } \\
5 \text { and } 9 \text { days p.i. }\end{array}$ & i.p. & $\begin{array}{l}1.75 \mathrm{mg} \text { of lipid } \\
\text { per injection }\end{array}$ & $\begin{array}{l}\text { C57BL/6 female } \\
\text { mice }(8 \text { weeks } \\
\text { old) with EAE } \\
\text { induced with } \\
\text { MOG }\end{array}$ & $\begin{array}{l}\text { Liposomes } \\
\text { successfully delayed } \\
\text { the onset, suppressed } \\
\text { the severity and } \\
\text { decreased the } \\
\text { incidence of the } \\
\text { disease. }\end{array}$ \\
\hline $\begin{array}{l}\text { (mannosylated) } \\
\text { SUV [189] }\end{array}$ & $\sim 85$ & -7.5 to -10.5 & $\begin{array}{l}\mathrm{MBP}_{46-62} \\
\text { MBP }_{124-139} \\
\text { MBP }_{147-170}\end{array}$ & -190 & - & $\begin{array}{l}\text { Preclinical/Therapeutic: } \\
\text { admin. on day } 7 \text { post } \\
\text { immunization } \\
\text { followed by five } \\
\text { consecutive days. }\end{array}$ & s.c. & & $\begin{array}{l}\text { Female DA rats } \\
\text { (8-9 weeks old) } \\
\text { with EAE } \\
\text { induced with a } \\
\text { syngeneic } \\
\text { spinal cord } \\
\text { homogenate or } \\
\text { with MBP } 63-81 \text {. }\end{array}$ & $\begin{array}{l}\text { It was revealed that } \\
\text { mSUVs loaded with } \\
\text { immunodominant } \\
\text { epitopes of MBP } \\
\text { could significantly } \\
\text { suppress EAE in } \\
\text { DA rats. }\end{array}$ \\
\hline \multicolumn{11}{|l|}{ Exosomes } \\
\hline $\begin{array}{l}\text { mTGF- } \beta 1- \\
\text { EXOs [215] }\end{array}$ & $50-100$ & & & & & $\begin{array}{l}\text { Prophylactic: } 8,5 \text {, and } \\
2 \text { days b.i. } \\
\text { Therapeutic: } \\
\text { 14, } 17 \text { and } 21 \text { days p.i. }\end{array}$ & i.v. & $\begin{array}{l}10 \mu \mathrm{gg} / \\
\text { mouse/ } \\
\text { injection }\end{array}$ & $\begin{array}{l}\text { Female C57BL/6 } \\
\text { mice } \\
\text { (6-8 weeks) } \\
\text { with EAE } \\
\text { induced with } \\
\text { MOG }_{35-55} \\
\text { Female BALB/c } \\
\text { mice } \\
\text { (6-8 weeks) } \\
\text { with EAE } \\
\text { induced with } \\
\text { PLP }_{180-199}\end{array}$ & $\begin{array}{l}\text { Treatment with } \\
\text { mTGF- } \beta 1 \text {-EXOs from } \\
\text { C57BL/6 mice } \\
\text { successfully inhibited } \\
\text { the development and } \\
\text { progression of the } \\
\text { disease in both mice } \\
\text { strains. }\end{array}$ \\
\hline
\end{tabular}


Table 5. Cont.

\begin{tabular}{|c|c|c|c|c|c|c|c|c|c|c|}
\hline Carrier & $\begin{array}{l}\text { Particle Size } \\
(\mathrm{nm})\end{array}$ & $\begin{array}{l}\text { Zeta Potential } \\
(\mathrm{mV})\end{array}$ & Antigen & $\begin{array}{l}\text { Ag Loading } \\
\text { (wt \%)/Enc. Eff. (\%) }\end{array}$ & $\begin{array}{l}\text { Immunomodul. } \\
\text { Agent }\end{array}$ & Vaccination Type & Admin. Route & Dose & Animal Model & Vaccination Outcome \\
\hline \multicolumn{11}{|c|}{ Antigen-presenting yeast cells } \\
\hline $\begin{array}{l}\text { C. utilis } \\
\text { expressing } \\
\text { MOG }_{35-55} \text { on its } \\
\text { surface [216] }\end{array}$ & - & - & $\begin{array}{l}\mathrm{MOG}_{35-55} \\
\text { pCB13 } \\
\text { pCB10 }\end{array}$ & & & $\begin{array}{l}\text { Prophylactic: admin. } \\
\text { on day } 7 \text { prior to } \\
\text { immunization and for } \\
\text { six consecutive days }\end{array}$ & Oral & $1.5 \times 10^{8}$ C. utilis & $\begin{array}{l}\text { Female C57BL/6 } \\
\text { mice (eight } \\
\text { weeks old) with } \\
\text { EAE induced } \\
\text { with } \text { MOG }_{35-55}\end{array}$ & $\begin{array}{l}\text { C. utilis expressing } \\
\text { MOG }_{35-55} \text { on its } \\
\text { surface appeared to } \\
\text { be a promising } \\
\text { approaach to protect } \\
\text { myelin against } \\
\text { autoimmunity by } \\
\text { effectively inducing } \\
\text { oral tolerance. Fungal } \\
\text { viability was not } \\
\text { found to affect the } \\
\text { induction of } \\
\text { tolerance. }\end{array}$ \\
\hline
\end{tabular}

PLGA: poly(lactide-co-glycolide); NPs: nanoparticles; MOG: myelin oligodendrocyte glycoprotein; (r) IL-10: recombinant interleukin; s.c.: subcutaneous; b.i.: before immunization; p.i.:

post immunization; EAE: experimental autoimmune encephalomyelitis; PLP: proteolipid protein; TGF- $\beta$ : transforming growth factor beta 1; i.v.: intravenous; MPs: microparticles; GM-CSF: granulocyte-macrophage colony-stimulating factor; PEMA: poly[ethylene-alt-maleic anhydride]; i.p.: intraperitoneal; PEG: polyethylene glycol; PLA: polylactide; PEI: polyethylene imine; Ac-PLP-BPI-NH2-2: (Ac-HSLGKWLGHPDKF-(AcpGAcpGAcp)2-ITDGEATDSG-NH2; Ac = acetyl, Acp = aminocaproic acid); CS: chitosan; SAgAs: soluble antigen arrays; HA: hyaluronic acid; LABL: ICAm-I binding peptide; CSAgAs: Click Soluble Antigen Arrays; i.p.: intraperitoneal; i.m.: intramuscular; iPEMs: immune polyelectrolyte multilayers; GpG: GpG oligonucleotide; MOGR3: MOG conjugated to tri-arginine; MOGR1 and MOGR2: MOG modified with either one or two cationic arginine residues; SUV: small unilamellar vesicles; mTGF- $\beta 1$-EXOs: exosomes from dendritic cells expressing membrane-associated TGF- $\beta 1$. 


\section{Clinical Trials}

Various tolerance-inducing vaccination approaches (e.g., immunodominant myelin epitopes, APLs, DNA vaccination, attenuated autologous myelin reactive T cells, tolerogenic DCs, TCR peptide vaccination, nanocarriers loaded with encephalitogenic myelin peptides, etc.) with promising outcomes in experimental MS models have already reached the clinical development phase. Their safety, feasibility, and efficiency in inducing antigen-specific immune tolerance and reducing MRI-detected disease activity in patients with relapsing remitting and progressive MS have been preliminary demonstrated in phase I and II clinical trials [14,136,139] (Table 6).

\section{Conclusions}

Several exciting vaccination strategies targeting the induction of antigen-specific immune tolerance in MS have been developed during the last decades, based on a single epitope or cocktails of immunodominant epitopes of myelin proteins, altered peptide ligands, DNA vaccines, tolerogenic DCs pulsed with myelin peptides, attenuated autologous myelin reactive T cells, TCR peptide vaccines, conjugates of autoantigens with various types of cells, and different types of carriers (e.g., particles, vesicles, self-assembled structures, or molecular carriers) associated with myelin epitopes. Most of these approaches have demonstrated promising results in animal models of experimental autoimmune encephalomyelitis both in prophylactic and therapeutic vaccination protocols. They successfully prevented the disease or delayed the disease onset, reduced its clinical and pathological symptoms and decreased the number of relapses, or, in a therapeutic scheme, they reversed the clinical and histological signs of the disease. Accordingly, numerous of the abovementioned strategies reached the clinical development phase, and their safety, feasibility, and efficacy were assessed in both phase I and II clinical trials. However, the results from these trials have not indicated the same level of efficiency as in preclinical models. Even though different tolerance-inducing vaccination strategies were proven safe and well tolerated, and in some cases succeeded in inducing tolerogenic responses to patients, no major advances have been reported with respect to clinical efficiency. Consequently, despite the intensive research efforts, up to the present time, no FDA approved antigen-specific immunotherapy is available for treating MS patients. It appears that antigen-specific immunotherapies still face various major challenges such as the involvement of multiple autoantigens that can vary between patients, the epitope spreading, the vaccination of patients with inapparent infections, etc. These challenges need to be overcome in order to allow tolerogenic vaccines to play a major role in the treatment of MS patients. Progress in the scientific areas of recombinant protein expression, genome editing, and smartly designed carriers, combined with better understanding of MS immunopathogenesis and improved immunization protocols, could potentially improve these vaccination strategies in the future. Additionally, further clinical studies, such as phase II and III, including placebo groups, will be required in order to more realistically assess the clinical effectiveness of these interesting antigen-specific immunotherapies in both RRMS and SPMS patients. 
Table 6. Clinical trials

\begin{tabular}{|c|c|c|c|c|c|}
\hline Objective & Phase & No. of Particip. & Antigen Immunotherapy & Admin. Route/Dose/Duration of Treatment & Results \\
\hline $\begin{array}{l}\text { To suppress disease activity in RRMS } \\
\text { patients using CGP77116 [74] }\end{array}$ & II & 24 & CGP77116 & $\begin{array}{l}\text { s.c. injection/ } 50 \mathrm{mg} \text { CGP77116 per week; } 5 \mathrm{mg} \\
\text { per week; } 5 \mathrm{mg} \text { per month } / 9 \text { months }\end{array}$ & $\begin{array}{l}\text { Decrease of dose because of adverse effects. } \\
\text { Trial termination due to treatment-related } \\
\text { disease exacerbation. }\end{array}$ \\
\hline $\begin{array}{l}\text { Evaluation of NBI } 5788 \text { safety, and effect } \\
\text { on RRMS patients [217] }\end{array}$ & II & 144 & NBI5788 & $\begin{array}{l}\text { s.c. injection/5, 20, or } 50 \mathrm{mg} \text { NBI5788 per } \\
\text { week/4 months }\end{array}$ & $\begin{array}{l}\text { Trial suspension due to hypersensitivity } \\
\text { reactions in some patients. No increase in } \\
\text { relapses. Reduction of number and volume } \\
\text { of enhancing lesions in patients who } \\
\text { completed the trial receiving } 5 \mathrm{mg} \text { of } \\
\text { NBI5788 per week. }\end{array}$ \\
\hline $\begin{array}{l}\text { Assessment of safety, tolerability and } \\
\text { clinical activity of AG284 in SPMS } \\
\text { patients [218] }\end{array}$ & I & 33 & AG284 & $\begin{array}{l}\text { /0.6, } 2,6,20,60,105 \text {, and } 150 \mathrm{mg} \mathrm{AG} 284 / \mathrm{kg} \\
\text { body weight; each dose was received daily for } \\
\text { three alternate days/ }\end{array}$ & $\begin{array}{l}\text { No adverse events but also no significant } \\
\text { therapeutic effect could be observed. }\end{array}$ \\
\hline $\begin{array}{l}\text { Assessment of the clinical efficiency of } \\
\text { MBP } 82-98 \text { in patients with progressive } \\
\text { MS [219] }\end{array}$ & II & 32 & $\mathrm{MBP}_{82-98}$ & i.v./500 mg MBP $82-98$ per 6 months/24 months & $\begin{array}{l}\text { Only patients with HLA haplotypes DR2 } \\
\text { and/or DR4 appeared to have benefited from } \\
\text { the treatment. }\end{array}$ \\
\hline $\begin{array}{l}\text { Evaluation of the safety and efficiency } \\
\text { of MBP } \text { M2-98 in SPMS patients with HLA } \\
\text { haplotypes DR2 and/or DR4 [220] }\end{array}$ & III & 612 & $\mathrm{MBP}_{82-98}$ & i.v. $/ 500 \mathrm{mg} \mathrm{MBP}_{82-98}$ per 6 months/2 years & $\begin{array}{l}\text { The administration of was safe and well } \\
\text { tolerated. The treatment was not effective in } \\
\text { SPMS patients with HLA DR2 } 2^{+} \text {or DR4 } 4^{+}\end{array}$ \\
\hline $\begin{array}{l}\text { Evaluation of RTL1000 safety in MS } \\
\text { patients [221] }\end{array}$ & $\mathrm{I}$ & 34 & RTL1000 & i.v./2, 6, 20, 60,200 , and $100 \mathrm{mg}$ of RTL/ & RTL1000 was safe at doses $\leq 60 \mathrm{mg}$ \\
\hline $\begin{array}{l}\text { Determination of the maximum } \\
\text { tolerable dose and safety of RTL1000 in } \\
\text { MS patients [222] }\end{array}$ & I & 36 & RTL1000 & i.v. $/ 2,6,20,60,200$, and $100 \mathrm{mg}$ of RTL/ & $\begin{array}{l}\text { The maximum tolerable dose of RTL100 was } \\
60 \mathrm{mg} \text {. }\end{array}$ \\
\hline $\begin{array}{l}\text { Examination of the effect of high dose } \\
\text { MBP }_{82-98} \text { on the number of regulatory T } \\
\text { cells in CPMS patients [223] }\end{array}$ & & 10 & $\mathrm{MBP}_{82-98}$ & i.v./500 mg of $\mathrm{MBP}_{82-98}$ per 6 months/ & $\begin{array}{l}\text { Increase in the number of regulatory T cells } \\
\text { in patients' PBMCs six weeks and six } 6 \\
\text { months after treatment. Renversement of the } \\
\text { state of T cell anergy. }\end{array}$ \\
\hline $\begin{array}{l}\text { Assessment of safety and tolerability of } \\
\text { autologous PBMCs coupled with } 7 \\
\text { myelin peptides in RRMS and SPMS } \\
\text { patients [224] }\end{array}$ & I & 9 & $\begin{array}{l}\text { PBMCs chemically coupled with } \\
\text { the following } 7 \text { myelin peptides: } \\
\text { MOG }_{1-20}, \text { MOG }_{35-55}, \text { MBP }_{13-32} \text {, } \\
\text { MBP }_{83-99}, \mathrm{MBP}_{111-129}, \mathrm{MBP}_{146-170} \\
\text { and PLP }\end{array}$ & $\begin{array}{l}\text { Single infusion } / 1 \times 10^{3}, 1 \times 10^{5}, 1 \times 10^{7}, 1 \times 10^{8}, \\
1 \times 10^{9}, 2.5 \times 10^{9} \text { and } 3 \times 10^{9} \text { antigen-coupled } \\
\text { PBMCs } / 3 \text { months }\end{array}$ & $\begin{array}{l}\text { The treatment was found to be safe and } \\
\text { well-tolerated. Antigen-specific T cell } \\
\text { responses were shown to decrease after } \\
\text { treatment in patients who received doses } \geq 1 \\
\times 10^{9} \text { of antigen coupled PBMCs. }\end{array}$ \\
\hline $\begin{array}{l}\text { Examination of BHT-3009 safety and } \\
\text { feasibility for immune nodulation in } \\
\text { RRMS and SPMS patients [225] }\end{array}$ & $\mathrm{I} / \mathrm{II}$ & 30 & BHT-3009 & $\begin{array}{l}\text { i.m. } / 0.5,1.5, \text { and } 3 \mathrm{mg} \text { of BHT- } 3009 \text { at weeks } 1 \text {, } \\
3,5, \text { and } 9 \text { after patients' randomization into } \\
\text { the clinical trial/The administration of } \\
\text { BHT- } 3009 \text { was combined or not with daily oral } \\
\text { administration of } 80 \mathrm{mg} \text { atorvastatin. }\end{array}$ & $\begin{array}{l}\text { BHT- } 3009 \text { was found to be safe and to induce } \\
\text { antigen-specific immune tolerance in MS } \\
\text { patients. The co-administration of } \\
\text { atorvastatin was not considered substantially } \\
\text { beneficial. }\end{array}$ \\
\hline $\begin{array}{l}\text { Assessment of the transdermal delivery } \\
\text { of a mixture of three myelin peptides to } \\
\text { induce immune tolerance in RRMS } \\
\text { patients [226] }\end{array}$ & & 30 & $\begin{array}{l}\text { Mixture of the following } 3 \\
\text { myelin peptides: } \mathrm{MBP}_{85-99} \\
\text { PLP }_{139-151} \text {, and } \mathrm{MOG}_{35-55}\end{array}$ & $\begin{array}{l}\text { Transdermal (via an adhesive skin patch)/ } 1 \text { or } \\
10 \mathrm{mg} \text { of each myelin peptide per week (for } 4 \\
\text { weeks) and per month (for } 11 \text { months)/ } 1 \text { year }\end{array}$ & $\begin{array}{l}\text { The transdermal administration of myelin } \\
\text { peptides was proven to be tolerogenic in } \\
\text { RRMS patients. }\end{array}$ \\
\hline
\end{tabular}


Table 6. Cont

\begin{tabular}{|c|c|c|c|c|c|}
\hline Objective & Phase & No. of Particip. & Antigen Immunotherapy & Admin. Route/Dose/Duration of Treatment & Results \\
\hline $\begin{array}{l}\text { Assessment of safety and efficiency of } \\
\text { transdermal administration of myelin } \\
\text { peptides in RRMS patients [227] }\end{array}$ & & 30 & $\begin{array}{l}\text { Mixture of the following three } \\
\text { myelin peptides: MBP } \\
\text { MOG }_{35-55} \text {, and PLP } \\
\text { PL9-151 }\end{array}$ & $\begin{array}{l}\text { Transdermal (via an adhesive skin patch)/ } 1 \text { or } \\
10 \mathrm{mg} \text { of each myelin peptide per week (for } \\
\text { four weeks) and per month (for } 11 \text { months)/1 } \\
\text { year }\end{array}$ & \multirow{3}{*}{$\begin{array}{l}\text { The transdermal delivery of myelin peptides } \\
\text { was found to be safe, well tolerated and to } \\
\text { reduce clinical symptoms and number of } \\
\text { Gadolinium lesions in RRMS patients. } \\
\text { It was shown that treatment with the lower } \\
\text { dose of BHT- } 3009 \text { (e.g., } 0.5 \mathrm{mg} \text { ) succeeded in } \\
\text { inducing antigen-specific immune tolerance } \\
\text { in some patients in contrast with the higher } \\
\text { dose (e.g., } 1.5 \mathrm{mg} \text { ) which was found to be } \\
\text { ineffective. } \\
\text { The safety and tolerability of ATX-MS-1467 } \\
\text { at a dose } \leq 800 \text { Hg, was successfully } \\
\text { demonstrated in SPMS patients. }\end{array}$} \\
\hline $\begin{array}{l}\text { Evaluation of BHT-3009 regarding its } \\
\text { safety and efficiency to induce immune } \\
\text { tolerance in RRMS patients }[228,229]\end{array}$ & II & 289 & BHT-3009 & $\begin{array}{l}\text { i.m./ } 0.5 \text { and } 1.5 \mathrm{mg} \text { of BHT- } 3009 \text { at weeks } 0,2 \text {, } \\
4 \text {, and every four weeks until week } 44 / \text { The } \\
\text { administration of BHT- } 3009 \text { was combined or } \\
\text { not with daily oral administration of } 80 \mathrm{mg} \\
\text { atorvastatin. }\end{array}$ & \\
\hline $\begin{array}{l}\text { Evaluation of ATX-MS-1467 safety in } \\
\text { SPMS patients [117] }\end{array}$ & I & 6 & ATX-MS-1467 & $\begin{array}{l}\text { i.d/25, 50, } 100,400 \text {, and } 800 \mu \mathrm{g} \text { of } \\
\text { ATX-MS-1467/ }\end{array}$ & \\
\hline $\begin{array}{l}\text { Evaluation of ATX-MS- } 1467 \text { safety, } \\
\text { tolerability and efficiency to induce } \\
\text { tolerance in RRMS patients [230] }\end{array}$ & $\mathrm{Ib}$, Ila & 43,37 & ATX-MS-1467 & $\begin{array}{l}\text { Ib: i.d. (cohort } 1 \text { ) or s.c. (cohort 2)/25, } 50,100, \\
400 \text { and } 800 \mu \mathrm{g} \text { of ATXMS-1467 per two weeks } \\
\text { (for eight weeks) and } 800 \mu \mathrm{g} \text { per two weeks } \\
\text { (for eight more weeks)/one year (including } 32 \\
\text { weeks medication off study). } \\
\text { IIa: i.d./50 } \mu \mathrm{g} \text { of ATXMS-1467 (on day 1), } 200 \\
\mu \mathrm{g} \text { (on day 15), } 800 \mu \mathrm{g} \text { (on day 29), and } 800 \mu \mathrm{g} \\
\text { per two weeks (for } 16 \text { more weeks)/one year } \\
\text { (including } 16 \text { weeks medication off study). }\end{array}$ & $\begin{array}{l}\text { Both treatment protocols were found to be } \\
\text { safe. The relatively slow i.d. titration of } \\
\text { ATX-MS- } 1467 \text { followed by a longer high } \\
\text { dose treatment period resulted in reduced } \\
\text { GdE lesions which remained so even post } \\
\text { treatment. }\end{array}$ \\
\hline \multicolumn{6}{|l|}{ Tolerogenic DCs (tolDCs) } \\
\hline $\begin{array}{l}\text { Evaluation of the safety of myelin } \\
\text { peptide loaded tolDCs and their ability } \\
\text { of to induce immune tolerance in MS } \\
\text { patients. [231] }\end{array}$ & I & 8 & $\begin{array}{l}\text { Autologous tolDCs loaded with } \\
\text { myelin peptides }\end{array}$ & $\begin{array}{l}\text { i.v. } / 50 \times 10^{6}, 100 \times 10^{6}, 150 \times 10^{6} \text {, and } 300 \times 10^{6} \\
\text { tolDCs divided in three independent doses } \\
\text { administered every two weeks/ }\end{array}$ & $\begin{array}{l}\text { Myelin peptide loaded tolDCs were proven } \\
\text { to be safe and well tolerated, and to induce } \\
\text { tolerogenic responses in MS patients. }\end{array}$ \\
\hline $\begin{array}{l}\text { Evaluation of the safety of intradermal } \\
\text { and intranodal delivery myelin peptide } \\
\text { loaded tolDCs and their efficacy } \\
\text { regarding the induction of } \\
\text { antigen-specific tolerization in MS } \\
\text { patients [232] }\end{array}$ & I & $9-15$ & $\begin{array}{l}\text { Autologous peptide-mix loaded } \\
\text { tolDCs }\end{array}$ & $\begin{array}{l}\text { i.d. or intranodal/six repetitive doses of } 5 \times 10^{6} \text {, } \\
10 \times 10^{6} \text { and } 15 \times 10^{6} \text { autologous peptide-mix } \\
\text { loaded tolDCs: administration of doses } 1-4 \\
\text { once every two weeks and of doses } 5-6 \text { once } \\
\text { every month. }\end{array}$ & - \\
\hline
\end{tabular}


Table 6. Cont

\begin{tabular}{|c|c|c|c|c|c|}
\hline Objective & Phase & No. of Particip. & Antigen Immunotherapy & Admin. Route/Dose/Duration of Treatment & Results \\
\hline \multicolumn{6}{|l|}{ T-cell vaccination (TCVs) } \\
\hline $\begin{array}{l}\text { Assessment of safety and immune } \\
\text { efficiency of a polyclonal T cell vaccine } \\
\text { in chronic MS patients in advanced } \\
\text { diseases stages [233] }\end{array}$ & & 39 & autological polyclonal TCVs & $\begin{array}{l}\text { s.c. } / 1.5-3 \times 10^{7} \text { polyclonal } \mathrm{T} \text { cells; four weekly } \\
\text { injections followed by monthly injections. }\end{array}$ & $\begin{array}{l}\text { Polyclonal TCV was proven safe and capable } \\
\text { of inducing long-lasting, anti-inflammatory } \\
\text { immune effects in progressive MS patients in } \\
\text { advanced disease states. }\end{array}$ \\
\hline $\begin{array}{l}\text { To establish a safe and efficient dose of } \\
\text { Tovaxin }{ }^{\circledR}[234]\end{array}$ & & 9-15 & $\begin{array}{l}\text { Attenuated T cells reactive to the } \\
\text { following myelin peptides } \\
\text { MBP }_{83-99}, \text { MBP }_{151-170} \text {, PLP } \\
\text { PLP }_{30-49} \text {, } \\
\text { MOG }_{19-39}, \text { MOG }_{1-17} \text { and }\end{array}$ & $\begin{array}{l}\text { s.c. } / 6-9 \times 10^{6}, 30-45 \times 10^{6} \text {, and } 60-90 \times 10^{6} \\
\text { administered at weeks } 0,4,12 \text {, and } 20 /\end{array}$ & $\begin{array}{l}\text { The study indicated the mid-dose as } \\
\text { optimum with respect to safety, and } \\
\text { efficiency in reducing peripheral blood } \\
\text { myelin reactive T cells and showing a trend } \\
\text { to improve clinical symptoms. } \\
\text { s.c. administration of Tovaxin was shown to }\end{array}$ \\
\hline $\begin{array}{l}\text { Evaluation of safety and efficacy of } \\
\text { Tovaxin in RRMS patients [235] }\end{array}$ & $\mathrm{Ilb}$ & 150 & $\begin{array}{l}\text { T cells reactive to different } \\
\text { immunodominant peptides from } \\
\text { three myelin proteins }\end{array}$ & s.c./five injections at weeks $0,4,8,12$, and 24 & $\begin{array}{l}\text { be safe. Evidence of clinical efficiency of } \\
\text { Tovaxin }{ }^{\circledR} \text { was observed during the analysis } \\
\text { of subgroups of patients naive to prior } \\
\text { disease modifying therapies. }\end{array}$ \\
\hline $\begin{array}{l}\text { Examination of TCV safety and } \\
\text { efficiency in progressive MS } \\
\text { patients [236] }\end{array}$ & II & 26 & $\begin{array}{l}\text { T-cell lines reactive to nine } \\
\text { different peptides of MBP, MOG } \\
\text { and PLP. }\end{array}$ & $\begin{array}{l}19 \text { patients received s.c. TCV/10-30 } \times 10^{6} \mathrm{~T} \\
\text { cells, on days } 1,30,90 \text { and } 180 / 7 \text { patients } \\
\text { received sham injections. }\end{array}$ & $\begin{array}{l}\text { The clinical trial demonstrated the safety of } \\
\text { TCV in progressive MS patients and } \\
\text { indicated its clinical efficiency. }\end{array}$ \\
\hline $\begin{array}{l}\text { Assessment of TCV safety and immune } \\
\text { modulation in RRMS and CPMS } \\
\text { patients [237] }\end{array}$ & pilot & 5 & $\begin{array}{l}\text { CSF derived activated CD4+T } \\
\text { cells }\end{array}$ & 3 s.c. injections; $10^{6}$ cells at months 2,4 , and 6 . & $\begin{array}{l}\text { TCV was safe and well tolerated. Patients } \\
\text { were clinically stable or exhibited reduced } \\
\text { EDSS without relapses during and post } \\
\text { treatment. }\end{array}$ \\
\hline $\begin{array}{l}\text { Examine if the depletion of } \mathrm{T} \text { cells } \\
\text { reactive to MBP would have a clinical } \\
\text { benefit for RRMS and SPMS } \\
\text { patients [238] }\end{array}$ & Preliminary & 54 & $\begin{array}{l}\text { Irradiated autologous T cells } \\
\text { reactive to MBP- }\end{array}$ & $\begin{array}{l}3 \text { s.c. injections at } 2 \text { month intervals, } 30 \times \\
10^{6}-60 \times 10^{6} \text { cells per injection. }\end{array}$ & $\begin{array}{l}\text { A } 40 \% \text { decrease in the relapses rate and a } \\
\text { minimal decrease in EDSS was observed in } \\
\text { RRMS patients. On the other hand, a slight } \\
\text { increase of EDSS was detected in SPMS } \\
\text { patients. Finally, MRI scans indicated a } \\
\text { stabilization of the lesion activity. }\end{array}$ \\
\hline $\begin{array}{l}\text { Assess the use of } \mathrm{T} \text { cell lines reacting } \\
\text { with a broad range of antigens regarding } \\
\text { targeting and depletion of specific } \mathrm{T} \\
\text { cells reactive to a great number of } \\
\text { myelin antigens in SPMS patients. [239] }\end{array}$ & Pilot & 4 & $\begin{array}{l}\text { Peripheral blood derived } \mathrm{T} \text { cell } \\
\text { lines reactive to bovine myelin }\end{array}$ & & $\begin{array}{l}\text { TCV with T cells reactive to whole bovine } \\
\text { myelin were shown to efficiently promote } \\
\text { depletion of circulating T cells reactive to } \\
\text { myelin protein. }\end{array}$ \\
\hline $\begin{array}{l}\text { Evaluation of the TCV efficiency in } \\
\text { patients with aggressive RRMS } \\
\text { non-responding to DMTs [240] }\end{array}$ & & 20 & $\begin{array}{l}\text { Autologous attenuated T cell } \\
\text { lines reactive to MBP and MOG } \\
\text { encephalitogenic peptides. }\end{array}$ & $\begin{array}{l}\text { Three s.c. injections in six- to eight-week } \\
\text { intervals. }\end{array}$ & $\begin{array}{l}\text { TCV was proven to be safe. A decrease in the } \\
\text { relapse rate was observed. Additionally, } \\
\text { significant decrease in the active lesions } \\
\text { regarding number and volume as well as in } \\
\text { T2 lesion burden was detected. }\end{array}$ \\
\hline $\begin{array}{l}\text { Identification of the idiotypic } \\
\text { determinants triggering CD } 81 \text { cytotoxic } \\
\text { anti-idiotypic responses by TCV in MS } \\
\text { patients [241] }\end{array}$ & & 3 & $\begin{array}{l}\text { Irradiated autologous } \mathrm{T} \text { cell } \\
\text { clones reactive to } \mathrm{MBP}_{83-99}\end{array}$ & $\begin{array}{l}\text { s.c./repetitive injections of } 2 \times 10^{7} \text { of each cell } \\
\text { clone every } 2 \text { months for } 8 \text { months. }\end{array}$ & $\begin{array}{l}\text { CD3-specific T cells were recognized as a } \\
\text { representative anti-idiotypic population of T } \\
\text { cells induced by TCV. }\end{array}$ \\
\hline
\end{tabular}


Table 6. Cont.

\begin{tabular}{|c|c|c|c|c|c|}
\hline Objective & Phase & No. of Particip. & Antigen Immunotherapy & Admin. Route/Dose/Duration of Treatment & Results \\
\hline \multicolumn{6}{|l|}{ T-cell receptor (TCR) } \\
\hline $\begin{array}{l}\text { To examine the therapeutic potential of } \\
\text { a trivalent TCR vaccine in MS } \\
\text { patients [242] }\end{array}$ & & 23 & $\begin{array}{l}\text { A trivalent TCR vaccine } \\
\text { containing the CDR2 peptides } \\
\text { BV5S2, BV6S5 and BV13S1 }\end{array}$ & 12 monthly vaccinations & $\begin{array}{l}\text { The therapeutic TCR vaccine induced an } \\
\text { extended immunoregulatory network which } \\
\text { could control complex self-reactive } \\
\text { responses of MS. }\end{array}$ \\
\hline \multicolumn{6}{|l|}{ Liposomes } \\
\hline $\begin{array}{l}\text { Assessment of Xemys safety and } \\
\text { efficiency in treating RRMS and SPMS } \\
\text { patients non-responding to } \\
\text { DMTs [191,192] }\end{array}$ & I & 20 & $\begin{array}{l}\text { Xemys: Liposomes loaded with } \\
\mathrm{MBP}_{46-62} \text {, MBP } 124-139 \text { and } \\
\mathrm{MBP}_{147-170} \text { And targeting CD206 }\end{array}$ & $\begin{array}{l}\text { s.c./six weekly injections of 50, 150, 225, 450, } \\
900 \text {, and } 900 \mu \mathrm{g} \text { Xemys }\end{array}$ & $\begin{array}{l}\text { The administration of Xemys was proven to } \\
\text { be safe and well tolerated, and to normalize } \\
\text { cytokine levels in RRMS and SPMS patients. }\end{array}$ \\
\hline
\end{tabular}

RRMS: relapsing remitting multiple sclerosis; CGP77116: APL of MBP 83-99; APL: antigen peptide ligand; MBP: myelin basic protein; s.c.: subcutaneous; NBI 5788: APL of MBP 83-99; AG284: solubilized complex of HLA-DR2 with MBP ${ }_{84-102}$; HLA: human leucocyte antigen; SPMS: secondary progressive multiple sclerosis; i.v.: intravenous; RTL1000: recombinant T-cell receptor ligand 1000; CPMS: chronic progressive multiple sclerosis; PBMCs: peripheral blood mononuclear cells; BHT-3009: tolerizing DNA vaccine encoding MBP; i.m.: intramuscular; ATX-MS-1467: mixture of equal quantities of synthetic peptides ATX-MS1 (MBP $\left.{ }_{30-44}\right)$, ATX-MS4 (MBP $\left.131-145\right)$, ATX-MS6 (MBP $\left.140-154\right)$, and ATX-MS7 (MBP $\left.83-99\right)$ in PBS; PBS: phosphatebuffered saline; i.d.: intradermal; tolDCs: tolerogenic dendritic cells; Tovaxin ${ }^{\circledR}$ : autologous T-cell immunotherapy; MOG:, PLP:; CSF:; DMTs: disease modifying therapies; CDR2: complementarity determining region 2 . 
Author Contributions: O.K. and C.K. contributed equally to the conceptualization, writing/preparation of the original draft, and writing-review and editing of the final paper. All authors have read and agreed to the published version of the manuscript.

Funding: This research received no external funding.

Conflicts of Interest: The authors declare no conflict of interest.

\section{References}

1. Harrington, E.P.; Bergles, D.E.; Calabresi, P.A. Immune cell modulation of oligodendrocyte lineage cells. Neurosci. Lett. 2020, 715, 134601. [CrossRef]

2. Baecher-Allan, C.; Kaskow, B.J.; Weiner, H.L. Multiple sclerosis: Mechanisms and immunotherapy. Neuron 2018, 97, 742-768. [CrossRef] [PubMed]

3. Dendrou, C.A.; Fugger, L.; Friese, M.A. Immunopathology of multiple sclerosis. Nature Rev. Immunol. 2015, 15, 545-558. [CrossRef] [PubMed]

4. Afshar, B.; Khalifehzadeh-Esfahani, Z.; Seyfizadeh, N.; Danbaran, G.R.; Hemmatzadeh, M.; Mohammadi, H. The role of immune regulatory molecules in multiple sclerosis. J. Neuroimmunol. 2019, 337, 577061. [CrossRef] [PubMed]

5. Greer, J.M.; Pender, M.P. Myelin proteolipid protein: An effective autoantigen and target of autoimmunity in multiple sclerosis. J. Autoimmun. 2008, 31, 281-287. [CrossRef] [PubMed]

6. Iwanowski, P.; Losy, J. Immunological differences between classical phenothypes of multiple sclerosis. J. Neurol. Sci. 2015, 349, 10-14. [CrossRef]

7. Lee, D.-H.; Linker, R.A. The role of myelin oligodendrocyte glycoprotein in autoimmune demyelination: A target for multiple sclerosis therapy? Expert Opin. Ther. Targets 2012, 16, 451-462. [CrossRef]

8. Rangachari, M.; Kuchroo, V.K. Using EAE to better understand principles of immune function and autoimmune pathology. J. Autoimmun. 2013, 45, 31-39. [CrossRef]

9. Lüssi, F.; Zipp, F.; Witsch, E. Dendritic cells as therapeutic targets in neuroinflammation. Cell. Mol. Life Sci. 2016, 73, 2425-2450. [CrossRef]

10. Ho, P.P.; Fontoura, P.; Platten, M.; Sobel, R.A.; DeVoss, J.J.; Lee, L.Y.; Kidd, B.A.; Tomooka, B.H.; Capers, J.; Agrawal, A.; et al. A Suppressive oligodeoxynucleotide enhances the efficacy of myelin cocktail/IL-4-tolerizing DNA vaccination and treats autoimmune disease. J. Immunol. 2005, 175, 6226-6234. [CrossRef]

11. Hemmer, B.; Nessler, S.; Zhou, D.; Kieseier, B.; Hartung, H.-P. Immunopathogenesis and immunotherapy of multiple sclerosis. Nat. Clin. Prac. Neurol. 2006, 2, 201-211. [CrossRef] [PubMed]

12. Hellings, N.; Raus, J.; Stinissen, P. T-cell based immunotherapy in multiple sclerosis: Induction of regulatory immune networks by T-cell vaccination. Expert Rev. Clin. Immunol. 2006, 2, 705-716. [CrossRef] [PubMed]

13. Zhou, Y.; Fang, L.; Peng, L.; Qiu, W. TLR9 and its signaling pathway in multiple sclerosis. J. Neurol. Sci. 2017, 373, 95-99. [CrossRef] [PubMed]

14. Willekens, B.; Cools, N. Beyond the magic bullet: Current progress of therapeutic vaccination in multiple sclerosis. CNS Drugs 2018, 32, 401-410. [CrossRef]

15. Skaper, S.D. Chapter 4-Oligodendrocyte precursor cells as a therapeutic target for demyelinating diseases, Prog. Brain Res. 2019, 245, 119-144. [CrossRef]

16. Gholamzad, M.; Ebtekar, M.; Ardestani, M.S.; Azimi, M.; Mahmodi, Z.; Mousavi, M.J.; Aslani, S. A comprehensive review on the treatment approaches of multiple sclerosis: Currently and in the future. Inflamm. Res. 2019, 68, 25-38. [CrossRef]

17. Derfuss, T. Personalized medicine in multiple sclerosis: Hope or reality? BMC Medicine. 2012, $10,116$. [CrossRef]

18. Lassmann, H. Pathogenic mechanisms associated with different clinical courses of multiple sclerosis. Front. Immunol. 2019, 9, 3116. [CrossRef]

19. Xie, Z.-X.; Zhang, H.-L.; Wu, X.-J.; Zhu, J.; Ma, D.-H.; Jin, T. Role of the immunogenic and tolerogenic subsets of dendritic cells in multiple sclerosis. Mediat. Inflamm. 2015, 20, 513295. [CrossRef]

20. Rostami, A.; Ciric, B. Role of Th17 cells in the pathogenesis of CNS inflammatory demyelination. J. Neurol. Sci. 2013, 333, 76-87. [CrossRef]

21. Baldassari, L.E.; Fox, R.J. Therapeutic advances and challenges in the treatment of progressive multiple sclerosis. Drugs 2018, 78, 1549-1566. [CrossRef] [PubMed] 
22. Magliozzi, R.; Howell, O.; Vora, A.; Serafini, B.; Nicholas, R.; Puopolo, M.; Reynolds, R.; Aloisi, F. Meningeal B-cell follicles in secondary progressive multiple sclerosis associate with early onset of disease and severe cortical pathology. Brain 2007, 130, 1089-1104. [CrossRef] [PubMed]

23. Dolati, S.; Babaloo, Z.; Jadidi-Niaragh, F.; Ayromlou, H.; Sadreddini, S.; Yousefi, M. Multiple sclerosis: Therapeutic applications of advancing drug delivery systems. Biomed. Pharmacother. 2017, 86, 343-353. [CrossRef] [PubMed]

24. Wucherpfennig, K.W.; Strominger, J.L. Molecular mimicry in T cell-mediated autoimmunity: Viral peptides activate human T cell clones specific for myelin basic protein. Cell 1995, 80, 695-705. [CrossRef]

25. Fujinami, R.S.; von Herrath, M.G.; Christen, U.; Whitton, J.L. Molecular mimicry, bystander activation, or viral persistence: Infections and autoimmune disease. Clin. Microbiol. Rev. 2006, 19, 80-94. [CrossRef] [PubMed]

26. Kim, T.-S.; Shin, E.-C. The activation of bystander CD8+ T cells and their roles in viral infection. Exp. Mol. Med. 2019, 51, 154. [CrossRef]

27. Giacomini, P.S.; Bar-Or, A. Antigen-specific therapies in multiple sclerosis. Expert Opin. Emerg. Drugs 2009, 14, 551-560. [CrossRef]

28. Szczepanik, M. Mechanisms of immunological tolerance to the antigens of the central nervous system. Skin-induced tolerance as a new therapeutic concept. J. Physiol. Pharmacol. 2011, 62, 159-165.

29. Hellings, N.; Raus, J.; Stinissen, P. T-cell vaccination in multiple sclerosis: Update on clinical application and mode of action. Autoimmun. Rev. 2004, 3, 267-275. [CrossRef]

30. Irvine, D.J.; Hanson, M.C.; Rakhra, K.; Tokatlian, T. Synthetic nanoparticles for vaccines and immunotherapy. Chem. Rev. 2015, 115, 11109-11146. [CrossRef]

31. Selter, R.C.; Hemmer, B. Update on immunopathogenesis and immunotherapy in multiple sclerosis. Immunotargets Ther. 2013, 2, 21-30. [CrossRef]

32. Lim, E.T.; Giovannoni, G. Immunopathogenesis and immunotherapeutic approaches in multiple sclerosis. Expert Rev. Neurother. 2005, 5, 379-390. [CrossRef] [PubMed]

33. Grigoriadis, N.; van Pesch, V. A basic overview of multiple sclerosis immunopathology. Eur. J. Neurol. 2015, 22, 3-13. [CrossRef] [PubMed]

34. Sie, C.; Korn, T.; Mitsdoerffer, M. Th17 cells in central nervous system autoimmunity. Exp. Neurol. 2014, 262, 18-27. [CrossRef] [PubMed]

35. García-González, P.; Ubilla-Olguín, G.; Catalán, D.; Schinnerling, K.; Aguillón, J.C. Tolerogenic dendritic cells for reprogramming of lymphocyte responses in autoimmune diseases. Autoimmun. Rev. 2016, 15, 1071-1080. [CrossRef] [PubMed]

36. AGreenfield, L.; Hauser, S.L. B Cell therapy for multiple sclerosis: Entering an era. Ann. Neurol. 2018, 83, 13-26. [CrossRef] [PubMed]

37. Lu, L.-F.; Rudensky, A. Molecular orchestration of differentiation and function of regulatory T cells. Genes Dev. 2009, 23, 1270-1282. [CrossRef] [PubMed]

38. Gregori, S.; Goudy, K.S.; Roncarolo, M.G. The cellular and molecular mechanisms of immuno-suppression by human type 1 regulatory T cells. Front. Immunol. 2012, 3, 30. [CrossRef]

39. Lu, W.; Chen, S.; Lai, C.; Lai, M.; Fang, H.; Dao, H.; Kang, J.; Fan, J.; Guo, W.; Fu, L.; et al. Suppression of HIV replication by CD8(+) regulatory T cells in elite controllers. Front. Immunol. 2016, 7, 134. [CrossRef]

40. Vuddamalay, Y.; van Meerwijk, J.P.M. CD28- and CD28lowCD8+ regulatory T cells: Of mice and men. Front. Immunol. 2017, 8, 31. [CrossRef]

41. Milo, R. Therapeutic strategies targeting B-cells in multiple sclerosis. Autoimmun. Rev. 2016, 15, 714-718. [CrossRef]

42. Zhang, Y.; Salter, A.; Wallström, E.; Cutter, G.; Stüve, O. Evolution of clinical trials in multiple sclerosis. Ther. Adv. Neurol. Disord. 2019, 12,1-14. [CrossRef]

43. Dargahi, N.; Katsara, M.; Tselios, T.; Androutsou, M.-E.; de Courten, M.; Matsoukas, J.; Apostolopoulos, V. Multiple sclerosis: Immunopathology and treatment update. Brain Sci. 2017, 7, 78. [CrossRef] [PubMed]

44. Gentile, A.; Musella, A.; de Vito, F.; Rizzo, F.R.; Fresegna, D.; Bullitta, S.; Vanni, V.; Guadalupi, L.; Bassi, M.S.; Buttari, F.; et al. Immunomodulatory effects of exercise in experimental multiple sclerosis. Front. Immunol. 2019, 10, 2197. [CrossRef] [PubMed]

45. Pasquier, R.A.D.; Pinschewer, D.D.; Merkler, D. Immunological mechanism of action and clinical profile of disease-modifying treatments in multiple sclerosis. CNS Drugs 2014, 28, 535-558. [CrossRef] 
46. Tapeinos, C.; Battaglini, M.; Ciofani, G. Advances in the design of solid lipid nanoparticles and nanostructured lipid carriers for targeting brain diseases. J. Control. Release 2017, 264, 306-332. [CrossRef]

47. Cross, A.H.; Naismith, R.T. Established and novel disease-modifying treatments in multiple sclerosis. J. Intern. Med. 2014, 275, 350-363. [CrossRef]

48. Piehl, F. A changing treatment landscape for multiple sclerosis: Challenges and opportunities. J. Intern. Med. 2014, 275, 364-381. [CrossRef]

49. Wingerchuk, D.M.; Carter, J.L. Multiple Sclerosis: Current and Emerging Disease-Modifying Therapies and Treatment Strategies. Mayo Clin. Proc. 2014, 89, 225-240. [CrossRef]

50. Tramacere, I.; del Giovane, C.; Salanti, G.; D'Amico, R.; Pacchetti, I.; Filippini, G. Immunomodulators and immunosuppressants for relapsing-remitting multiple sclerosis: A network meta-analysis. Cochrane Database Syst. Rev. 2015, 9, CD011381. [CrossRef]

51. Wraith, D.C. The future of immunotherapy: A 20-year perspective. Front. Immunol. 2017, 8, 1668. [CrossRef] [PubMed]

52. D'Amico, E.; Patti, F.; Zanghì, A.; Zappia, M. A personalized approach in progressive multiple sclerosis: The current status of disease modifying therapies (DMTs) and future perspectives. Int. J. Mol. Sci. 2016, 17, 1725. [CrossRef] [PubMed]

53. Ciotti, J.R.; Cross, A.H. Disease-Modifying Treatment in Progressive Multiple Sclerosis. Curr. Treat. Options Neurol. 2018, 20, 12. [CrossRef] [PubMed]

54. Lassmann, H. Targets of therapy in progressive MS. Mult. Scler. 2017, 23, 1593-1599. [CrossRef]

55. Novartis Receives FDA Approval for Mayzent@(Siponimod), the First Oral Drug to Treat Secondary Progressive MS with Active Disease. Available online: https://novartis.gcs-web.com/Novartis-receives-FDAapproval-for-Mayzent-siponimod-the-first-oral-drug-to-treat-secondary-progressive-MS-with-activedisease?_ga=2.241998658.1110943223.1587297344-1758107691.1587297344 (accessed on 14 April 2020).

56. Zeposia (Ozanimod). Available online: https://multiplesclerosisnewstoday.com/zeposia-ozanimod-rpc1063rrms/ (accessed on 14 April 2020).

57. Cladribine. Available online: https://en.wikipedia.org/wiki/Cladribine (accessed on 14 April 2020).

58. Wildner, P.; Selmaj, K.W. Multiple sclerosis: Skin-induced antigen-specific immune tolerance. J. Neuroimmunol. 2017, 311, 49-58. [CrossRef]

59. Sospedra, M.; Martin, R. Antigen-Specific Therapies in Multiple Sclerosis. Int. Rev. Immunol. 2005, 24, 393-413. [CrossRef]

60. Blanchfield, J.L. Antigen-specific tolerogenic vaccines inhibit autoimmune disease in a rodent model of multiple sclerosis. Ph.D. Thesis, The Faculty of the Department of Microbiology and Immunology Brody School of Medicine at East Carolina University, Greenville, USA, 2010.

61. Pickens, C.J.; Christopher, M.A.; Leon, M.A.; Pressnall, M.M.; Johnson, S.N.; Thati, S.; Sullivan, B.P.; Berkland, C. Antigen-drug conjugates as a novel therapeutic class for the treatment of antigen-specific autoimmune disorders. Mol. Pharm. 2019, 16, 2452-2461. [CrossRef]

62. Chunsong, Y.; Jingchao, X.; Meng, L.; Myunggi, A.; Haipeng, L. Bioconjugate strategies for the induction of antigen-specific tolerance in autoimmune diseases. Bioconjug. Chem. 2018, 29, 29719-29732. [CrossRef]

63. Mannie, M.D.; Curtis, A.D. II Tolerogenic vaccines for multiple sclerosis. Hum. Vac. Immunother. 2013, 9, 1032-1038. [CrossRef]

64. Yannakakis, M.P.; Tzoupis, H.; Michailidou, E.; Mantzourani, E.; Simal, C.; Tselios, T. Molecular dynamics at the receptor level of immunodominant myelin oligodendrocyte glycoprotein 35-55 epitope implicated in multiple sclerosis. J. Mol. Graph. Model. 2016, 68, 78-86. [CrossRef]

65. Lutterotti, A.; Martin, R. Antigen-specific tolerization approaches in multiple sclerosis. Expert Opin. Investig. Drugs 2014, 23, 9-20. [CrossRef] [PubMed]

66. Wraith, D. Antigen-specific immunotherapy. Nature 2016, 530, 422-423. [CrossRef] [PubMed]

67. Spence, A.; Klementowicz, J.E.; Bluestone, J.A.; Tang, Q. Targeting Treg signaling for the treatment of autoimmune diseases. Curr. Opin. Immunol. 2015, 37, 11-20. [CrossRef] [PubMed]

68. Sabatos-Peyton, C.A.; Verhagen, J.; Wraith, D.C. Antigen-specific immunotherapy of autoimmune and allergic diseases. Curr. Opin. Immunol. 2010, 22, 609-615. [CrossRef] [PubMed]

69. Steinman, L. The re-emergence of antigen-specific tolerance as a potential therapy for MS. Mult. Scler. J. 2015, 21, 1223-1238. [CrossRef] [PubMed] 
70. Cappellano, G.; Comi, C.; Chiocchetti, A.; Dianzani, U. Exploiting PLGA-based biocompatible nanoparticles for next-generation tolerogenic vaccines against autoimmune disease. Int. J. Mol. Sci. 2019, $20,204$. [CrossRef]

71. Vanderlugt, C.L.; Miller, S.D. Epitope spreading inimmune-mediated diseases: Implications for immunotherapy. Nat. Rev. Immunol. 2002, 2, 85-95. [CrossRef]

72. Miller, S.D.; Turley, D.M.; Podojil, J.R. Antigen-specific tolerance strategies for the prevention and treatment of autoimmune disease. Nat. Rev. Immunol. 2007, 7, 665-677. [CrossRef]

73. Lutterotti, A.; Sospedra, M.; Martin, R. Antigen-specific therapies in MS-Current concepts and novel approaches. J. Neurol. Sci. 2008, 274, 18-22. [CrossRef]

74. Bielekova, B.; Goodwin, B.; Richert, N.; Cortese, I.; Kondo, T.; Afshar, G.; Grani, B.; Eaton, J.; Antel, J.; Frank, J.A.; et al. Encephalitogenic potential of the myelin basic protein peptide (amino acids 83-99) in multiple sclerosis: Results of a phase II clinical trial with an altered peptide ligand. Nat. Med. 2000, 6, 1167-1175. [CrossRef]

75. Turley, D.M.; Miller, S.D. Prospects for antigen-specific tolerance based therapies for the treatment of multiple sclerosis, Results Probl. Cell Differ. 2010, 51, 217-235. [CrossRef]

76. Constantinescu, C.S.; Farooqi, N.; O’Brien, K.; Gran, B. Experimental autoimmune encephalomyelitis (EAE) as a model for multiple sclerosis (MS). Br. J. Pharmacol. 2011, 164, 1079-1106. [CrossRef] [PubMed]

77. Fletcher, J.M.; Lalor, S.J.; Sweeney, C.M.; Tubridy, N.; Mills, K.H. T cells in multiple sclerosis and experimental autoimmune encephalomyelitis. Clin. Exp. Immunol. 2010, 162,1-11. [CrossRef] [PubMed]

78. Libbey, J.E.; Fujinami, R.S. Experimental autoimmune encephalomyelitis as a testing paradigm for adjuvants and vaccines. Vaccine 2011, 29, 3356-3362. [CrossRef] [PubMed]

79. Tabansky, I.; Keskin, D.B.; Watts, D.; Petzold, C.; Funaro, M.; Sands, W.; Wright, P.; Yunis, E.J.; Najjar, S.; Diamond, B.; et al. Targeting DEC-205-DCIR2+ dendritic cells promotes immunological tolerance in proteolipid protein-induced experimental autoimmune encephalomyelitis. Mol. Med. 2018, 24, 17. [CrossRef]

80. Huang, X.; Lu, H.W.Q. The mechanisms and applications of $\mathrm{T}$ cell vaccination for autoimmune diseases: A comprehensive review. Clinic. Rev. Allerg. Immunol. 2014, 47, 219-233. [CrossRef] [PubMed]

81. Grau-López, L.; Raïch, D.; Ramo-Tello, C.; Naranjo-Gómez, M.; Dàvalos, A.; Pujol-Borrell, R.; Borràs, F.E.; Martínez-Cáceres, E. Myelin peptides in multiple sclerosis. Autoimmun. Rev. 2009, 8, 650-653. [CrossRef]

82. Kuchroo, V.K.; Anderson, A.C.; Waldner, H.; Munder, M.; Bettelli, E.; Nicholson, L.B. T cell response in experimental autoimmune encephalomyelitis (EAE): Role of Self and Cross-Reactive Antigens in Shaping, Tuning, and Regulating the Autopathogenic T Cell Repertoire. Annu. Rev. Immunol. 2002, 20, 101-123. [CrossRef]

83. Matsoukas, J.; Apostolopoulos, V.; Kalbacher, H.; Papini, A.-M.; Tselios, T.; Chatzantoni, K.; Biagioli, T.; Lolli, F.; Deraos, S.; Papathanassopoulos, P.; et al. Design and synthesis of a novel potent myelin basic protein epitope 87-99 cyclic analogue: Enhanced stability and biological properties of mimics render them a potentially new class of immunomodulators. J. Med. Chem. 2005, 48, 1470-1480. [CrossRef]

84. Reindl, M.; Waters, P. Myelin oligodendrocyte glycoprotein antibodies in neurological disease. Nat. Rev. Neurol. 2019, 15, 89-102. [CrossRef]

85. Kaushansky, N.; Eisenstein, M.; Zilkha-Falb, R.; Ben-Nun, A. The myelin-associated oligodendrocytic basic protein (MOBP) as a relevant primary target autoantigen in multiple sclerosis. Autoimmun. Rev. 2010, 9, 233-236. [CrossRef] [PubMed]

86. Androutsou, M.E.; Tapeinou, A.; Vlamis-Gardikas, A.; Tselios, T. Myelin oligodendrocyte glycoprotein and multiple sclerosis. Med. Chem. 2018, 14, 120-128. [CrossRef] [PubMed]

87. Tselios, T.; Aggelidakis, M.; Tapeinou, A.; Tseveleki, V.; Kanistras, I.; Gatos, D.; Matsoukas, J. Rational design and synthesis of altered peptide ligands based on human myelin oligodendrocyte glycoprotein 35-55 epitope: Inhibition of chronic experimental autoimmune encephalomyelitis in mice. Molecules 2014, 19, 17968-17984. [CrossRef] [PubMed]

88. Deraos, G.; Kritsi, E.; Matsoukas, M.-T.; Christopoulou, K.; Kalbacher, H.; Zoumpoulakis, P.; Apostolopoulos, V.; Matsoukas, J. Design of linear and cyclic mutant analogues of dirucotide peptide (MBP82-98) against multiple sclerosis: Conformational and binding studies to MHC Class II. Brain Sci. 2018, 8, 213. [CrossRef] [PubMed] 
89. Tapeinou, A.; Giannopoulou, E.; Hansen, C.S.B.E.; Kalofonos, H.; Apostolopoulosd, V.; Vlamis-Gardikas, A.; Tselios, T. Design, synthesis and evaluation of an anthraquinone derivative conjugated to myelin basic protein immunodominant (MBP85-99) epitope: Towards selective immunosuppression. Eur. J. Med. Chem. 2018, 143, 621-631. [CrossRef]

90. Yannakakis, M.-P.; Simal, C.; Tzoupis, H.; Rodi, M.; Dargahi, N.; Prakash, M.; Mouzaki, A.; Platts, J.A.; Apostolopoulos, V.; Tselios, T.V. Design and synthesis of non-peptide mimetics mapping the immunodominant myelin basic protein (MBP83-96) epitope to function as T-cell receptor antagonists. Int. J. Mol. Sci. 2017, 18, 1215. [CrossRef]

91. Correale, J.; Farez, M.; Gilmore, W. Vaccines for multiple sclerosis: Progress to date. CNS Drugs 2008, 22, 175-198. [CrossRef]

92. Mantzourani, E.D.; Platts, J.A.; Brancale, A.; Mavromoustakos, T.M.; Tselios, T.V. Molecular dynamics at the receptor level of immunodominant myelin basic protein epitope 87-99 implicated in multiple sclerosis and its antagonists altered peptide ligands: Triggering of immune response. J. Mol. Graph. Model. 2007, 26, 471-481. [CrossRef]

93. Kaushansky, N.; de Rosbo, N.K.; Zilkha-Falb, R.; Yosef-Hemo, R.; Cohen, L.; Ben-Nun, A. 'Multi-epitope-targeted' immune-specific therapy for a multiple sclerosis-like disease via engineered multi-epitope protein is superior to peptides. PLOS ONE 2011, 6, e27860. [CrossRef]

94. Kaushansky, N.; Kaminitz, A.; Allouche-Arnon, H.; Ben-Nun, A. Modulation of MS-like disease by a multi epitope protein is mediated by induction of CD11c+CD11b+ Gr1+ myeloid-derived dendritic cells. J. Neuroimmunol. 2019, 333, 476953. [CrossRef]

95. Moorman, C.D.; Curtis, A.D., 2nd; Bastian, A.G.; Elliott, S.E.; Mannie, M.D. A GMCSF-Neuroantigen Tolerogenic Vaccine Elicits Systemic Lymphocytosis of CD4+ CD25high FOXP3+ Regulatory T Cells in Myelin-Specific TCR Transgenic Mice Contingent Upon Low-Efficiency T Cell Antigen Receptor Recognition. Front. Immunol. 2019, 9, 3119. [CrossRef] [PubMed]

96. Mannie, M.D.; Blanchfield, J.L.; Islam, S.M.T.; Abbott, D.J. Cytokine-neuroantigen fusion proteins as a new class of tolerogenic, therapeutic vaccines for treatment of inflammatory demyelinating disease in rodent models of multiple sclerosis. Front. Immunol. 2012, 3, 255. [CrossRef] [PubMed]

97. Abbott, D.J.; Blanchfield, J.L.; Martinson, D.A.; Russell, S.C.; Taslim, N.; Curtis, A.D.; Mannie, M.D. Neuroantigen-specific, tolerogenic vaccines: GMCSF is a fusion partner that facilitates tolerance rather than immunity to dominant self-epitopes of myelin in murine models of experimental autoimmune encephalomyelitis (EAE). BMC Immunol. 2011, 12, 72. [CrossRef] [PubMed]

98. Blanchfield, J.L.; Mannie, M.D. A GMCSF-neuroantigen fusion protein is a potent tolerogen in experimental autoimmune encephalomyelitis (EAE) that is associated with efficient targeting of neuroantigen to APC. J. Leukoc. Biol. 2010, 87, 509-521. [CrossRef]

99. Petzold, C.; Schallenberg, S.; Stern, J.N.H.; Kretschmer, K. Targeted antigen delivery to DEC-205+ dendritic cells for tolerogenic vaccination. Rev. Diabet. Stud. 2012, 9, 305-318. [CrossRef]

100. Idoyaga, J.; Fiorese, C.; Zbytnuik, L.; Lubkin, A.; Miller, J.; Malissen, B.; Mucida, D.; Merad, M.; Steinman, R.M. Specialized role of migratory dendritic cells in peripheral tolerance induction. J. Clin. Investig. 2013, 123, 844-854. [CrossRef]

101. Stern, J.N.H.; Keskin, D.B.; Kato, Z.; Waldner, H.; Schallenberg, S.; Anderson, A.; von Boehmer, H.; Kretschmer, K.; Strominger, J.L. Promoting tolerance to proteolipid protein-induced experimental autoimmune encephalomyelitis through targeting dendritic cells. Proc. Natl. Acad. Sci. USA 2010, 107, 17280-17285. [CrossRef]

102. Ring, S.; Maas, M.; Nettelbeck, D.M.; Enk, A.H.; Mahnke, K. Targeting of autoantigens to DEC205+ dendritic cells in vivo suppresses experimental allergic encephalomyelitis in mice. J. Immunol. 2013, 191, 2938-2947. [CrossRef]

103. Kasagi, S.; Wang, D.; Zhang, P.; Zanvit, P.; Chen, H.; Zhang, D.; Li, J.; Che, L.; Maruyama, T.; Nakatsukasa, H.; et al. Combination of apoptotic $\mathrm{T}$ cell induction and self-peptide administration for therapy of experimental autoimmune encephalomyelitis. EBioMedicine 2019, 44, 50-59. [CrossRef]

104. Clemente-Casares, X.; Tsai, S.; Yang, Y.; Santamaria, P. Peptide-MHC-based nanovaccines for the treatment of autoimmunity: A “one size fits all” approach? J. Mol. Med. 2011, 89, 733-742. [CrossRef] 
105. Offner, H.; Sinha, S.; Wang, C.; Burrows, G.G.; Vandenbark, A.A. Recombinant T-cell receptor ligands: Immunomodulatory, neuroprotective and neuroregenerative effects suggest application as therapy for multiple sclerosis. Rev. Neurosci. 2008, 19, 327-339. [CrossRef] [PubMed]

106. Sinha, S.; Subramanian, S.; Emerson-Webber, A.; Lindner, M.; Burrows, G.G.; Grafe, M.; Linington, C.; Vandenbark, A.A.; Bernard, C.C.A.; Offner, H. Recombinant TCR ligand reverses clinical signs and CNS damage of EAE induced by recombinant human MOG. J. Neuroimmune Pharmacol. 2010, 5, 231-239. [CrossRef] [PubMed]

107. Gong, Y.; Wang, Z.; Liang, Z.; Duan, H.; Ouyang, L.; Yu, Q.; Xu, Z.; Shen, G.; Weng, X.; Wu, X. Soluble MOG35-55/I-Ab Dimers Ameliorate Experimental Autoimmune Encephalomyelitis by Reducing Encephalitogenic T Cells. PLoS ONE 2012, 7, e47435. [CrossRef] [PubMed]

108. Vandenbark, A.A.; Rich, C.; Mooney, J.; Zamora, A.; Wang, C.; Huan, J.; Fugger, L.; Offner, H.; Jones, R.; Burrows, G.G. Recombinant TCR ligand induces tolerance to myelin oligodendrocyte glycoprotein 35-55 peptide and reverses clinical and histological signs of chronic experimental autoimmune encephalomyelitis in HLA-DR2 transgenic mice. J. Immunol. 2003, 171, 127-133. [CrossRef]

109. White, D.R.; Khedri, Z.; Kiptoo, P.; Siahaan, T.J.; Tolbert, T.J. Synthesis of a bifunctional peptide inhibitor-IgG1 Fc fusion that suppresses experimental autoimmune encephalomyelitis. Bioconjug. Chem. 2017, 28, 1867-1877. [CrossRef]

110. Ridwan, R.; Kiptoo, P.; Kobayashi, N.; Weir, S.; Hughes, M.; Williams, T.; Soegianto, R.; Siahaan, T.J. Antigen-specific suppression of experimental autoimmune encephalomyelitis by a novel bifunctional peptide inhibitor: Structure optimization and pharmacokinetics. JPET 2010, 332, 1136-1145. [CrossRef]

111. Badawi, A.H.; Siahaan, T.J. Suppression of MOG- and PLP-induced experimental autoimmune encephalomyelitis using a novel multivalent bifunctional peptide inhibitor. J. Neuroimmunol. 2013, 263, 20-27. [CrossRef]

112. Majewska, M.; Zając, K.; Srebro, Z.; Sura, P.; Książek, L.; Zemelka, M.; Szczepanik, M. Epicutaneous immunization with myelin basic protein protects from the experimental autoimmune encephalomyelitis. Pharmacol. Rep. 2007, 59, 74-79.

113. Szczepanik, M.; Tutaj, M.; Bryniarski, K.; Dittel, B.N. Epicutaneously induced TGF-h-dependent tolerance inhibits experimental autoimmune encephalomyelitis. J. Neuroimmunol. 2005, 164, 105-114. [CrossRef]

114. Tutaj, M.; Szczepanik, M. Epicutaneous (EC) immunization with myelin basic protein (MBP) induces TCRabp CD4p CD8p double positive suppressor cells that protect from experimental autoimmune encephalomyelitis (EAE). J. Autoimmun. 2007, 28, 208-215. [CrossRef]

115. Li, H.; Zhang, G.-X.; Chen, Y.; Xu, H.; Fitzgerald, D.C.; Zhao, Z.; Rostami, A. CD11c+CD11b+ Dendritic cells play an important role in intravenous tolerance and the suppression of experimental autoimmune encephalomyelitis. J. Immunol. 2008, 181, 2483-2493. [CrossRef] [PubMed]

116. Lourbopoulos, A.; Deraos, G.; Matsoukas, M.-T.; Touloumi, O.; Giannakopoulou, A.; Kalbacher, H.; Grigoriadis, N.; Apostolopoulos, V.; Matsoukas, J. Cyclic MOG35-55 ameliorates clinical and neuropathological features of experimental autoimmune encephalomyelitis, Bioorgan. Med. Chem. 2017, 25, 4163-4174. [CrossRef] [PubMed]

117. Streeter, H.B.; Rigden, R.; Martin, K.F.; Scolding, N.J.; Wraith, D.C. Preclinical development and first-in-human study of ATX-MS-1467 for immunotherapy of MS. Neurol. Neuroimmunol. Neuroinflamm. 2015, 2, e93. [CrossRef] [PubMed]

118. Billetta, R.; Ghahramani, N.; Morrow, O.; Prakken, B.; de Jong, H.; Meschter, C.; Lanza, P.; Albani, S. Epitope-specific immune tolerization ameliorates experimental autoimmune encephalomyelitis. Clin. Immunol. 2012, 145, 94-101. [CrossRef]

119. Peron, J.P.S.; Yang, K.; Chen, M.-L.; Brandao, W.N.; Basso, A.S.; Commodaro, A.G.; Weiner, H.L.; Rizzo, L.V. Oral tolerance reduces Th17 cells as well as the overall inflammation in the central nervous system of EAE mice. J. Neuroimmunol. 2010, 227, 10-17. [CrossRef]

120. Song, F.; Guan, Z.; Gienapp, I.E.; Shawler, T.; Benson, J.; Whitacre, C.C. The thymus plays a role in oral tolerance in experimental autoimmune encephalomyelitis. J. Immunol. 2006, 177, 1500-1509. [CrossRef]

121. Deraos, G.; Rodi, M.; Kalbacher, H.; Chatzantoni, K.; Karagiannis, F.; Synodinos, L.; Plotas, P.; Papalois, A.; Dimisianos, N.; Papathanasopoulos, P.; et al. Properties of myelin altered peptide ligand cyclo(8-99)(Ala91,Ala96) MBP87-99 render it a promising drug lead for immunotherapy of multiple sclerosis. Eur. J. Med.Chem. 2015, 101, 13-23. [CrossRef] 
122. Islam, S.M.T.; Curtis, A.D., 2nd; Taslim, N.; Wilkinson, D.S.; Mannie, M.D. GM-CSF-neuroantigen fusion proteins reverse experimental autoimmune encephalomyelitis and mediate tolerogenic activity in adjuvant-primed environments: Association with inflammation-dependent, inhibitory antigen presentation. J. Immunol. 2014, 193, 2317-2329. [CrossRef]

123. Mannie, M.D.; Clayson, B.A.; Buskirk, E.J.; DeVine, J.L.; Hernandez, J.J.; Abbott, D.J. IL-2/Neuroantigen fusion proteins as antigen-specific tolerogens in experimental autoimmune encephalomyelitis (EAE): Correlation of T cell-mediated antigen presentation and tolerance induction. J. Immunol. 2007, 178, 2835-2843. [CrossRef]

124. Link, J.M.; Rich, C.M.; Korat, M.; Burrows, G.G.; Offner, H.; Vandenbark, A.A. Monomeric DR2/MOG-35-55 recombinant TCR ligand treats relapses of experimental encephalomyelitis in DR2 transgenic mice. Clin. Immunol. 2007, 123, 95-104. [CrossRef]

125. Huan, J.; Subramanian, S.; Jones, R.; Rich, C.; Link, J.; Mooney, J.; Bourdette, D.N.; Vandenbark, A.A.; Burrows, G.G.; Offner, H. Monomeric recombinant TCR ligand reduces relapse rate and severity of experimental autoimmune encephalomyelitis in SJL/J mice through cytokine switch. J. Immunol. 2004, 172, 4556-4566. [CrossRef] [PubMed]

126. Offner, H.; Subramanian, S.; Wang, C.; Afentoulis, M.; Vandenbark, A.A.; Huan, J.; Burrows, G.G. Treatment of passive experimental autoimmune encephalomyelitis in SJL mice with a recombinant TCR ligand induces IL-13 and prevents axonal injury. J. Immunol. 2005, 175, 4103-4111. [CrossRef] [PubMed]

127. Sinha, S.; Subramanian, S.; Proctor, T.M.; Kaler, L.J.; Grafe, M.; Dahan, R.; Huan, J.; Vandenbark, A.A.; Burrows, G.G.; Offner, H. A promising therapeutic approach for multiple sclerosis: Recombinant T-cell receptor ligands modulate experimental autoimmune encephalomyelitis by reducing interleukin-17 production and inhibiting migration of encephalitogenic cells into the CNS. J. Neurosci. 2007, 27, 12531-12539. [CrossRef] [PubMed]

128. Sinha, S.; Subramanian, S.; Miller, L.; Proctor, T.M.; Roberts, C.; Burrows, G.G.; Vandenbark, A.A.; Offner, H. Cytokine switch and bystander suppression of autoimmune responses to multiple antigens in experimental autoimmune encephalomyelitis by a single recombinant T-Cell receptor ligand. J. Neurosci. 2009, 29, 3816-3823. [CrossRef] [PubMed]

129. Sinha, S.; Miller, L.; Subramanian, S.; McCarty, O.; Proctor, T.; Meza-Romero, R.; Burrows, G.G.; Vandenbark, A.A.; Offner, H. Binding of recombinant T cell receptor ligands (RTL) to antigen presenting cells prevents upregulation of $\mathrm{CD} 11 \mathrm{~b}$ and inhibits $\mathrm{T}$ cell activation and transfer of experimental autoimmune encephalomyelitis. J. Neuroimmunol. 2010, 225, 52-61. [CrossRef] [PubMed]

130. Wang, C.; Gold, B.G.; Kaler, L.J.; Yu, X.; Afentoulis, M.E.; Burrows, G.G.; Vandenbark, A.A.; Bourdette, D.N.; Offner, H. Antigen-specific therapy promotes repair of myelin and axonal damage in established EAE. J. Neurochem. 2006, 98, 1817-1827. [CrossRef] [PubMed]

131. Badawi, A.H.; Kiptoo, P.; Siahaan, T.J. Immune tolerance induction against experimental Autoimmune Encephalomyelitis (EAE) Using A New PLP-B7AP Conjugate that simultaneously targets B7/CD28 costimulatory signal and TCR/MHC-II signal. J. Mult. Scler. (Foster City) 2015, 2, 1000131.

132. Badawi, A.H.; Kiptoo, P.; Wang, W.-T.; Choi, I.-Y.; Lee, P.; Vines, C.M.; Siahaan, T.J. Suppression of EAE and prevention of blood-brain barrier breakdown after vaccination with novel bifunctional peptide inhibitor. Neuropharmacology 2012, 62, 1874-1881. [CrossRef]

133. Kobayashi, N.; Kobayashi, H.; Gu, L.; Malefyt, T.; Siahaan, T.J. Antigen-specific suppression of experimental autoimmune encephalomyelitis by a novel bifunctional peptide inhibitor. JPET 2007, 322, 879-886. [CrossRef]

134. Kobayashi, N.; Kiptoo, P.; Kobayashi, H.; Ridwan, R.; Brocke, S.; Siahaan, T.J. Prophylactic and therapeutic suppression of experimental autoimmune encephalomyelitis by a novel bifunctional peptide inhibitor. Clin. Immunol. 2008, 129, 69-79. [CrossRef]

135. Kiptoo, P.; Büyüktimkin, B.; Badawi, A.H.; Stewart, J.; Ridwan, R.; Siahaan, T.J. Controlling immune response and demyelination using highly potent bifunctional peptide inhibitors in the suppression of experimental autoimmune encephalomyelitis. Clin. Exp. Immunol. 2012, 172, 23-36. [CrossRef] [PubMed]

136. Fissolo, N.; Montalban, X.; Comabella, M. DNA vaccination techniques. Methods Mol. Biol. 2016, 1304, 39-50. [CrossRef] [PubMed]

137. Garren, H. DNA vaccines for autoimmune diseases. Expert Rev. Vaccines 2009, 8, 1195-1203. [CrossRef] [PubMed]

138. Fontoura, P.; Garren, H.; Steinman, L. Antigen-specific therapies in multiple sclerosis: Going beyond proteins and peptides. Int. Rev. Immunol. 2005, 24, 415-446. [CrossRef] [PubMed] 
139. Fissolo, N.; Montalban, X.; Comabella, M. DNA-based vaccines for multiple sclerosis: Current status and future directions. Clin. Immunol. 2012, 142, 76-83. [CrossRef]

140. Stuve, O.; Cravens, P.; Eagar, T.N. DNA-based vaccines: The future of multiple sclerosis therapy? Expert Rev. Neurother. 2008, 8, 351-360. [CrossRef] [PubMed]

141. Jakimovski, D.; Weinstock-Guttman, B.; Ramanathan, M.; Dwyer, M.G.; Zivadinov, R. Infections, vaccines and autoimmunity: A multiple sclerosis perspective. Vaccines 2020, 8, 50. [CrossRef]

142. Garren, H.; Ruiz, P.J.; Watkins, T.A.; Fontoura, P.; Nguyen, L.-V.T.; Estline, E.R.; Hirschberg, D.L.; Steinman, L. Combination of gene delivery and DNA vaccination to protect from and reverse Th1 autoimmune disease via deviation to the Th2 pathway. Immunity 2001, 15, 15-22. [CrossRef]

143. Wefer, J.; Harris, R.A.; Lobell, A. Protective DNA vaccination against experimental autoimmune encephalomyelitis is associated with induction of IFNh. J. Neuroimmunol. 2004, 149, 66-76. [CrossRef]

144. Schif-Zuck, S.; Wildbaum, G.; Karin, N. Coadministration of plasmid DNA constructs encoding an encephalitogenic determinant and IL-10 elicits regulatory T cell-mediated protective immunity in the central nervous system. J. Immunol. 2006, 177, 8241-8247. [CrossRef]

145. Lobell, A.; Weissert, R.; Eltayeb, S.; de Graaf, K.L.; Wefer, J.; Storch, M.K.; Lassmann, H.; Wigzell, H.; Olsson, T. Suppressive DNA vaccination in myelin oligodendrocyte glycoprotein peptide-induced experimental autoimmune encephalomyelitis involves a T1-biased immune response. J. Immunol. 2003, 170, 1806-1813. [CrossRef] [PubMed]

146. Andersson, A.; Isaksson, M.; Wefer, J.; Norling, A.; Flores-Morales, A.; Rorsman, F.; Kämpe, O.; Harris, R.A.; Lobell, A. Impaired autoimmune $\mathrm{T}$ helper 17 cell responses following DNA vaccination against rat experimental autoimmune encephalomyelitis. PLoS ONE 2008, 3, e3682. [CrossRef] [PubMed]

147. Kang, Y.; Sun, Y.; Zhang, J.; Gao, W.; Kang, J.; Wang, Y.; Wang, B.; Xia, G. Treg cell resistance to apoptosis in DNA vaccination for experimental autoimmune encephalomyelitis treatment. PLOS ONE 2012, 7, e49994. [CrossRef] [PubMed]

148. Walczak, A.; Szymanska, B.; Selmaj, K. Differential prevention of experimental autoimmune encephalomyelitis with antigen-specific DNA vaccination. Clin. Neurol. Neurosurg. 2004, 106, 241-245. [CrossRef] [PubMed]

149. Liu, J.; Cao, X. Regulatory dendritic cells in autoimmunity: A comprehensive review. J. Autoimmun. 2015, 63, 1-12. [CrossRef] [PubMed]

150. Domogalla, M.P.; Rostan, P.V.; Raker, V.K.; Steinbrink, K. Tolerance through education: How tolerogenic dendritic cells shape immunity. Front. Immunol. 2017, 8, 1764. [CrossRef]

151. Van Brussel, I.; Lee, W.P.; Rombouts, M.; Nuyts, A.H.; Heylen, M.; DeWinter, B.Y.; Cools, N.; Schrijvers, D.M. Tolerogenic dendritic cell vaccines to treat autoimmune diseases: Can the unattainable dream turn into reality? Autoimmun. Rev. 2014, 13, 138-150. [CrossRef]

152. Flórez-Grau, G.; Zubizarreta, I.; Cabezón, R.; Villoslada, P.; Benitez-Ribas, D. Tolerogenic dendritic cells as a promising antigen-specific therapy in the treatment of multiple sclerosis and neuromyelitis optica from preclinical to clinical trials. Front. Immunol. 2018, 9, 1169. [CrossRef]

153. Obregon, C.; Kumar, R.; Pascual, M.A.; Vassalli, G.; Golshayan, D. Update on dendritic cell-induced immunological and clinical tolerance. Front. Immunol. 2017, 8, 1514. [CrossRef]

154. Derdelinckx, J.; Mansilla, M.J.; de Laere, M.; Lee, W.-P.; Navarro-Barriuso, J.; Wens, I.; Nkansah, I.; Daans, J.; de Reu, H.; Keliris, A.J.; et al. Clinical and immunological control of experimental autoimmune encephalomyelitis by tolerogenic dendritic cells loaded with MOG-encoding RNA. J. Neuroinflam. 2019, 16, 167. [CrossRef]

155. Iberg, C.A.; Hawiger, D. Natural and induced tolerogenic dendritic cells. J. Immunol. 2020, $204,733-744$. [CrossRef] [PubMed]

156. Vandenbark, A.A.; Abulafia-Lapid, R. Autologous T-cell vaccination for multiple sclerosis: A perspective on progress. BioDrugs 2008, 22, 265-273. [CrossRef] [PubMed]

157. Volovitz, I.; Marmora, Y.; Mor, F.; Flügel, A.; Odoardi, F.; Eisenbach, L.; Cohen, I.R. T cell vaccination induces the elimination of EAE effector T cells: Analysis using GFP-transduced, encephalitogenic T cells. J. Autoimmun. 2010, 35, 135-144. [CrossRef] [PubMed]

158. Turley, D.M.; Miller, S.D. Peripheral tolerance induction using ethylenecarbodiimide-fixed APCs uses both direct and indirect mechanisms of antigen presentation for prevention of experimental autoimmune encephalomyelitis. J. Immunol. 2007, 178, 2212-2220. [CrossRef] [PubMed] 
159. Getts, D.R.; Turley, D.M.; Smith, C.E.; Harp, C.T.; McCarthy, D.; Feeney, E.M.; Getts, M.T.; Martin, A.J.; Luo, X.; Terry, R.R.; et al. Tolerance Induced by Apoptotic Antigen-Coupled Leukocytes is Induced by PD-L1+, IL-10-Producing Splenic Macrophages and Maintained by Tregs. J. Immunol. 2011, 187, 2405-2417. [CrossRef] [PubMed]

160. Pishesha, N.; Bilate, A.M.; Wibowo, M.C.; Huang, N.-J.; Lia, Z.; Deshycka, R.; Bousbaine, D.; Lia, H.; Pattersona, H.C.; Dougana, S.K.; et al. Engineered erythrocytes covalently linked to antigenic peptides can protect against autoimmune disease. Proc. Natl. Acad. Sci. USA 2017, 114, 3157-3162. [CrossRef]

161. Chen, Z.; Yang, D.; Peng, X.; Lin, J.; Suc, Z.; Lia, J.; Zhang, X.; Weng, Y. Beneficial effect of atorvastatin-modified dendritic cells pulsed with myelin oligodendrocyte glycoprotein autoantigen on experimental autoimmune encephalomyelitis. Neuroreport 2018, 29,317-327. [CrossRef]

162. Wang, X.; Zhang, J.; Baylink, D.J.; Li1, C.-H.; Watts, D.M.; Xu, Y.; Qin, X.; Walter, M.H.; Tang, X. Targeting non-classical myelin epitopes to treat experimental autoimmune encephalomyelitis. Sci. Rep. 2016, 6, 36064. [CrossRef]

163. Kalantari, T.; Karimi, M.H.; Ciric, B.; Yan, Y.; Rostami, A.; Kamali-Sarvestani, E. Tolerogenic dendritic cells produced by lentiviral-mediated CD40- and interleukin-23p19-specific shRNA can ameliorate experimental autoimmune encephalomyelitis by suppressing T helper type 17 cells. Clin. Exp. Immunol. 2014, 176, 180-189. [CrossRef]

164. Mansilla, M.J.; Sellès-Moreno, C.; Fàbregas-Puig, S.; Amoedo, J.; Navarro-Barriuso, J.; Teniente-Serra, A.; Grau-López, L.; Ramo-Tello, C.; Martínez-Cáceres, E.M. Beneficial effect of tolerogenic dendritic cells pulsed with MOG autoantigen in experimental autoimmune encephalomyelitis. CNS Neurosci. Ther. 2015, 21, 222-230. [CrossRef]

165. Mansilla, M.J.; Contreras-Cardone, R.; Navarro-Barriuso, J.; Cools, N.; Berneman, Z.; Ramo-Tello, C.; Martínez-Cáceres, E.M. Cryopreserved vitamin D3-tolerogenic dendritic cells pulsed with autoantigens as a potential therapy for multiple sclerosis patients. J. Neuroinflamm. 2016, 13, 113. [CrossRef] [PubMed]

166. Zhou, Y.; Leng, X.; Luo, S.; Su, Z.; Luo, X.; Guo, H.; Mo, C.; Zou, Q.; Liu, Y.; Wang, Y. Tolerogenic dendritic cells generated with tofacitinib ameliorate experimental autoimmune encephalomyelitis through modulation of Th17/Treg balance. J. Immunol. Res. 2016, 2016, 5021537. [CrossRef] [PubMed]

167. Xie, Z.; Chen, J.; Zheng, C.; Wu, J.; Cheng, Y.; Zhu, S.; Lin, C.; Cao, Q.; Zhu, J.; Jin, T. 1,25-dihydroxyvitamin D3-induced dendritic cells suppress experimental autoimmune encephalomyelitis by increasing proportions of the regulatory lymphocytes and reducing T helper type 1 and type 17 cells. Immunology 2017, 152, 414-424. [CrossRef] [PubMed]

168. Papenfuss, T.L.; Powell, N.D.; McClain, M.A.; Bedarf, A.; Singh, A.; Gienapp, I.E.; Shawler, T.; Whitacre, C.C. Estriol generates tolerogenic dendritic cells in vivo that protect against autoimmunity. J. Immunol. 2011, 15, 186-3346. [CrossRef] [PubMed]

169. Menges, M.; Rößner, S.; Voigtländer, C.; Schindler, H.; Kukutsch, N.A.; Bogdan, C.; Erb, K.; Schuler, G.; Lutz, M.B. Repetitive injections of dendritic cells matured with tumor necrosis factor $\alpha$ induce antigen-specific protection of mice from autoimmunity. J. Exp. Med. 2002, 195, 15-21. [CrossRef] [PubMed]

170. Xiao, B.-G.; Huang, Y.-M.; Yang, J.-S.; Xu, L.-Y.; Link, H. Bone marrow-derived dendritic cells from experimental allergic encephalomyelitis induce immune tolerance to EAE in Lewis rats. Clin. Exp. Immunol. 2001, 125, 300-309. [CrossRef] [PubMed]

171. Kim, Y.C.; Zhang, A.-H.; Yoon, J.; Culp, W.E.; Leesa, J.R.; Wucherpfennig, K.W.; Scott, D.W. Engineered MBP-specific human Tregs ameliorate MOG-induced EAE through IL-2-triggered inhibition of effector T cells. J. Autoimmun. 2018, 92, 77-86. [CrossRef]

172. Pereira, B.d.; Fraefel, C.; Hilbe, M.; Ackermann, M.; Dresch, C. Transcriptional targeting of DCs with lentiviral vectors induces antigen-specific tolerance in a mouse model of multiple sclerosis. Gene Ther. 2013, 20, 556-566. [CrossRef]

173. Eixarch, H.; Espejo, C.; Gómez, A.; Mansilla, M.J.; Castillo, M.; Mildner, A.; Vidal, F.; Gimeno, R.; Prinz, M.; Montalban, X.; et al. Tolerance induction in experimental autoimmune encephalomyelitis using non-myeloablative hematopoietic gene therapy with autoantigen. Mol. Ther. 2009, 17, 897-905. [CrossRef]

174. Casacuberta-Serra, S.; Costa, C.; Eixarch, H.; Mansilla, M.J.; López-Estévez, S.; Martorell, L.; Parés, M.; Montalban, X.; Espejo, C.; Barquinero, J. Myeloid-derived suppressor cells expressing a self-antigen ameliorate experimental autoimmune encephalomyelitis. Exp. Neurol. 2016, 286, 50-60. [CrossRef] 
175. Tabansky, I.; Messina, M.D.; Bangeranye, C.; Goldstein, J.; Blitz-Shabbir, K.M.; Machado, S.; Jeganathan, V.; Wright, P.; Najjar, S.; Cao, Y.; et al. Advancing drug delivery systems for the treatment of multiple sclerosis. Immunol. Res. 2015, 63, 58-69. [CrossRef] [PubMed]

176. Ballerini, C.; Baldi, G.; Aldinucci, A.; Maggi, P. Nanomaterial applications in multiple sclerosis inflamed Brain. J. Neuroimmune Pharmacol. 2015, 10, 1-13. [CrossRef] [PubMed]

177. Gharagozloo, M.; Majewski, S.; Foldvari, M. Therapeutic applications of nanomedicine in autoimmune diseases: From immunosuppression to tolerance induction. Nanomed. Nanotechnol. 2015, 11, 1003-1018. [CrossRef] [PubMed]

178. Pires, L.R.; Marques, F.; Sousa, J.C.; Cerqueira, J.; Pinto, I.M. Nano- and micro-based systems for immunotolerance induction in multiple sclerosis. Hum. Vaccines Immunother. 2016, 12, 1886-1890. [CrossRef] [PubMed]

179. Veld, R.H.I.; da Silva, C.G.; Kaijzel, E.L.; Chan, A.B.; Cruz, L.J. The Potential of nano-vehicle mediated therapy in vasculitis and multiple sclerosis. Curr. Pharm. Des. 2017, 23, 1985-1992. [CrossRef]

180. Gammon, J.M.; Jewell, C.M. Engineering immune tolerance with biomaterials. Adv. Healthc. Mater. 2019, 8 , e1801419. [CrossRef]

181. Pei, W.; Wan, X.; Shahzad, K.A.; Zhang, L.; Song, S.; Jin, X.; Wang, L.; Zhao, C.; Shen, C. Direct modulation of myelin-autoreactive CD4+ and CD8+ T cells in EAE mice by a tolerogenic nanoparticle co-carrying myelin peptide-loaded major histocompatibility complexes, CD47 and multiple regulatory molecules. Int. J. Nanomed. 2018, 13, 3731-3750. [CrossRef]

182. Sestak, J.O.; Sullivan, B.P.; Thati, S.; Northrup, L.; Hartwell, B.; Antunez, L.; Forrest, M.L.; Vines, C.M.; Siahaan, T.J.; Berkland, C. Codelivery of antigen and an immune cell adhesion inhibitor is necessary for efficacy of soluble antigen arrays in experimental autoimmune encephalomyelitis. Mol. Ther. Methods Clin. Dev. 2014, 1, 14008. [CrossRef]

183. Thati, S.; Kuehl, C.; Hartwell, B.; Sestak, J.; Siahaan, T.; Forrest, M.L.; Berkland, C. Routes of Administration and dose optimization of soluble antigen arrays in mice with experimental autoimmune encephalomyelitis. J. Pharm. Sci. 2015, 104, 714-721. [CrossRef]

184. Hartwell, B.L.; Pickens, C.J.; Leon, M.; Berkland, C. Multivalent antigen arrays exhibit high avidity binding and modulation of $B$ cell receptor-mediated signaling to drive efficacy against experimental autoimmune encephalomyelitis. Biomacromolecules 2017, 18, 1893-1907. [CrossRef]

185. Hartwell, B.L.; Pickens, C.J.; Leon, M.; Northrup, L.; Christopher, M.; Griffin, J.D.; Martinez-Becerra, F.; Berkland, C. Soluble antigen arrays disarm antigen-specific B cells to promote lasting immune tolerance in experimental autoimmune encephalomyelitis. J. Autoimmun. 2018, 93, 76-88. [CrossRef] [PubMed]

186. Tostanoski, L.H.; Chiu, Y.-C.; Andorko, J.I.; Guo, M.; Zeng, X.; Zhang, P.; Royal, W., III; Jewell, C.M. Design of polyelectrolyte multilayers to promote immunological tolerance. ACS Nano 2016, 10, 9334-9345. [CrossRef] [PubMed]

187. Hess, K.L.; Andorko, J.I.; Tostanoski, L.H.; Jewell, C.M. Polyplexes assembled from self-peptides and regulatory nucleic acids blunt toll-like receptor signaling to combat autoimmunity. Biomaterials 2017, 118, 51-62. [CrossRef] [PubMed]

188. Tseveleki, V.; Tselios, T.; Kanistras, I.; Koutsoni, O.; Karamita, M.; Vamvakas, S.-S.; Apostolopoulos, V.; Dotsika, E.; Matsoukas, J.; Lassmann, H.; et al. Mannan-conjugated myelin peptides prime non-pathogenic Th1 and Th17 cells and ameliorate experimental autoimmune encephalomyelitis. Exp. Neurol. 2015, 267, 254-267. [CrossRef] [PubMed]

189. Belogurov, A.A., Jr.; Stepanov, A.V.; Smirnov, I.V.; Melamed, D.; Bacon, A.; Mamedov, A.E.; Boitsov, V.M.; Sashchenko, L.P.; Ponomarenko, N.A.; Sharanova, S.N.; et al. Liposome-encapsulated peptides protect against experimental allergic encephalitis. FASEB J. 2013, 27, 222-231. [CrossRef] [PubMed]

190. Pujol-Autonell, I.; Mansilla, M.-J.; Rodriguez-Fernandez, S.; Cano-Sarabia, M.; Navarro-Barriuso1, J.; Ampudia, R.-M.; Rius, A.; Garcia-Jimeno, S.; Perna-Barrull, D.; Martinez-Caceres, E.; et al. Liposome-based immunotherapy against autoimmune diseases: Therapeutic effect on multiple sclerosis. Nanomedicine 2017, 12, 1231-1242. [CrossRef]

191. Belogurov, A.; Zakharov, K.; Lomakin, Y.; Surkov, K.; Avtushenko, S.; Kruglyakov, P.; Smirnov, I.; Makshakov, G.; Lockshin, C.; Gregoriadis, G.; et al. CD206-targeted liposomal myelin basic protein peptides in patients with multiple sclerosis resistant to first-line disease-modifying therapies: A first-in-human, proof-of-concept dose-escalation study. Neurotherapeutics 2016, 13, 895-904. [CrossRef] 
192. Lomakin, Y.; Belogurov, A., Jr.; Glagoleva, I.; Stepanov, A.; Zakharov, K.; Okunola, J.; Smirnov, I.; Genkin, D.; Gabibov, A. Administration of myelin basic protein peptides encapsulated in mannosylated liposomes normalizes level of serum TNF- $\alpha$ and IL-2 and chemoattractants CCL2 and CCL4 in multiple sclerosis patients. Mediat. Inflamm. 2016, 2016, 2847232. [CrossRef]

193. Cappellano, G.; Woldetsadik, A.D.; Orilieri, E.; Shivakumar, Y.; Rizzi, M.; Carniato, F.; Gigliotti, C.L.; Boggio, E.; Clemente, N.; Comi, C.; et al. Subcutaneous inverse vaccination with PLGA particles loaded with aMOG peptide and IL-10 decreases the severity of experimental autoimmune encephalomyelitis. Vaccine 2014, 32, 5681-5689. [CrossRef]

194. Casey, L.M.; Pearson, R.M.; Hughes, K.R.; Liu, J.M.H.; Rose, J.A.; North, M.G.; Wang, L.Z.; Lei, M.; Miller, S.D.; Shea, L.D. Conjugation of transforming growth factor Beta to antigen-loaded Poly(lactide-co-glycolide) nanoparticles enhances efficiency of antigen-specific tolerance. Bioconjug. Chem. 2018, 29, 813-823. [CrossRef]

195. Cho, J.J.; Stewart, J.M.; Drashansky, T.T.; Brusko, M.A.; Zuniga, A.N.; Lorentsen, K.J.; Keselowsky, B.G.; Avram, D. An antigen-specific semi-therapeutic treatment with local delivery of tolerogenic factors through a dual-sized microparticle system blocks experimental autoimmune encephalomyelitis. Biomaterials 2017, 143, 79-92. [CrossRef] [PubMed]

196. Gholamzad, M.; Ebtekar, M.; Ardestani, M.S. Intravenous injection of myelin oligodendrocyte glycoprotein-coated PLGA microparticles have tolerogenic effects in experimental autoimmune encephalomyelitis. Iran J. Allergy Asthma Immunol. 2017, 16, 27-281.

197. Hunter, Z.; McCarthy, D.P.; Yap, W.T.; Harp, C.T.; Getts, D.R.; Shea, L.D.; Miller, S.D. A biodegradable nanoparticle platform for the induction of antigen-specific immune tolerance for treatment of autoimmune disease. ACS Nano 2014, 8, 2148-2160. [CrossRef] [PubMed]

198. Maldonado, R.A.; LaMothe, R.A.; Ferrari, J.D.; Zhang, A.-H.; Rossi, R.J.; Kolte, P.N.; Griset, A.P.; O’Neil, C.; Altreuter, D.H.; Browning, E.; et al. Polymeric synthetic nanoparticles for the induction of antigen-specific immunological tolerance. Proc. Natl. Acad. Sci. USA 2014, 112, E156-E165. [CrossRef]

199. McCarthy, D.P.; Yap, J.W.-T.; Harp, C.T.; Song, W.K.; Chen, J.; Pearson, R.M.; Miller, S.D.; Shea, L.D. An antigen-encapsulating nanoparticle platform for TH1/17 immune tolerance therapy. Nanomedicine 2017, 13, 191-200. [CrossRef]

200. Saito, E.; Kuo, R.; Kramer, K.R.; Gohel, N.; Giles, D.A.; Moore, B.B.; Miller, S.D.; Shea, L.D. Design of biodegradable nanoparticles to modulate phenotypes of antigen presenting cells for antigen-specific treatment of autoimmune disease. Biomaterials 2019, 222, 119432. [CrossRef]

201. Wan, X.; Pei, W.; Shahzad, K.A.; Zhang, L.; Song, S.; Jin, X.; Wang, L.; Zhao, C.; Shen, C. A Tolerogenic artificial APC durably ameliorates experimental autoimmune encephalomyelitis by directly and selectively modulating myelin peptide-autoreactive CD4 ${ }^{+}$and CD8 ${ }^{+}$T cell. J. Immunol. 2018, 201, 1194-1210. [CrossRef]

202. Zhao, H.; Kiptoo, P.; Williams, T.D.; Siahaan, T.J.; Topp, E.M. Immune response to controlled release of immunomodulating peptides in a murine experimental autoimmune encephalomyelitis (EAE) model. J. Control. Release 2010, 141, 145-152. [CrossRef]

203. Pearson, R.M.; Casey, L.M.; Hughes, K.R.; Wang, L.Z.; North, M.G.; Getts, D.R.; Miller, S.D.; Shea, L.D. Controlled delivery of single or multiple antigens in tolerogenic nanoparticles using peptide-polymer bioconjugates. Mol. Ther. 2017, 25, 1655-1664. [CrossRef]

204. Sestak, J.O.; Fakhari, A.; Badawi, A.H.; Siahaan, T.J.; Berkland, C. Structure, size, and solubility of antigen arrays determines efficacy in experimental autoimmune encephalomyelitis. AAPS J. 2014, 16, 1185-1193. [CrossRef]

205. Kuo, R.; Saito, E.; Miller, S.D.; Shea, L.D. Peptide-conjugated nanoparticles reduce positive co-stimulatory expression and T cell activity to induce tolerance. Mol. Ther. 2017, 25, 1676-1685. [CrossRef] [PubMed]

206. Getts, D.R.; Martin, A.J.; McCarthy, D.P.; Terry, R.L.; Hunter, Z.N.; Yap, W.T.; Getts, M.T.; Pleiss, M.; Luo, X.; King, N.J.C.; et al. Microparticles bearing encephalitogenic peptides induce T-cell tolerance and ameliorate experimental autoimmune encephalomyelitis. Nat. Biotechnol. 2012, 30, 1217-1224. [CrossRef] [PubMed]

207. Tostanoski, L.H.; Chiu, Y.-C.; Gammon, J.M.; Simon, T.; Andorko, J.I.; Bromberg, J.S.; Jewell, C.M. Reprogramming the local lymph node microenvironment promotes tolerance that is systemic and antigen-specific. Cell Rep. 2016, 16, 2940-2952. [CrossRef] [PubMed]

208. Büyüktimkin, B.; Wang, Q.; Kiptoo, P.; Stewart, J.M.; Berkland, C.; Siahaan, T.J. Vaccine-like controlled-release delivery of an immunomodulating peptide to treat experimental autoimmune encephalomyelitis. Mol. Pharm. 2012, 9, 979-985. [CrossRef] 
209. Northrup, L.; Sestak, J.O.; Sullivan, B.P.; Thati, S.; Hartwell, B.L.; Siahaan, T.J.; Vines, C.M.; Berkland, C. Co-delivery of autoantigen and B7 pathway modulators suppresses experimental autoimmune encephalomyelitis. AAPS J. 2014, 16, 1204-1213. [CrossRef]

210. Kuehl, C.; Thati, S.; Sullivan, B.; Sestak, J.; Thompson, M.; Siahaan, T.; Berkland, C. Pulmonary administration of soluble antigen arrays is superior to antigen in treatment of experimental autoimmune encephalomyelitis. J. Pharm. Sci. 2017, 106, 3293-3302. [CrossRef]

211. Hess, K.L.; Oh, E.; Tostanoski, L.H.; Andorko, J.I.; Susumu, K.; Deschamps, J.R.; Medintz, I.L.; Jewell, C.M. Engineering immunological tolerance using quantum dots to tune the density of self-antigen display. Adv. Funct. Mater. 2017, 27. [CrossRef]

212. Clemente-Casares, X.; Blanco, J.; Ambalavanan, P.; Yamanouchi, J.; Singha, S.; Fandos, C.; Tsai, S.; Wang, J.; Garabatos, N.; Izquierdo, C.; et al. Expanding antigen-specific regulatory networks to treat autoimmunity. Nature 2016, 530, 434-440. [CrossRef]

213. Yeste, A.; Nadeau, M.; Burns, E.J.; Weiner, H.L.; Qu, F.J. Nanoparticle-mediated codelivery of myelin antigen and a tolerogenic small molecule suppresses experimental autoimmune encephalomyelitis. Proc. Natl. Acad. Sci. USA 2012, 109, 11270-11275. [CrossRef]

214. Katsara, M.; Deraos, G.; Tselios, T.; Matsoukas, J.; Apostolopoulos, V. Design of novel cyclic altered peptide ligands of myelin basic protein MBP83-99 that modulate immune responses in SJL/J mice. J. Med. Chem. 2008, 51, 3971-3978. [CrossRef]

215. Yu, L.; Yang, F.; Jiang, L.; Chen, Y.; Wang, K.; Xu, F.; Wei, Y.; Cao, X.; Wang, J.; Cai, Z. Exosomes with membrane-associated TGF- $\beta 1$ from gene-modified dendritic cells inhibit murine EAE independently of MHC restriction. Eur. J. Immunol. 2013, 43, 2461-2472. [CrossRef] [PubMed]

216. Buerth, C.; Mausberg, A.K.; Heininger, M.K.; Hartung, H.-P.; Kieseier, B.C.; Ernst, J.F. Oral tolerance induction in experimental autoimmune encephalomyelitis with Candida utilis expressing the immunogenic MOG35-55 peptide. PLoS ONE 2016, 11, e0155082. [CrossRef] [PubMed]

217. Kappos, L.; Comi, G.; Panitch, H.; Oger, J.; Antel, J.; Conlon, P.; Steinman, L. The Altered peptide ligand in relapsing MS study group, Induction of a non-encephalitogenic type $2 \mathrm{~T}$ helper-cell autoimmune response in multiple sclerosis after administration of an altered peptide ligand in a placebo-controlled, randomized phase II trial. Nat. Med. 2000, 6, 1176-1182. [CrossRef] [PubMed]

218. Goodkin, D.E.; Shulman, M.; Winkelhake, J.; Waubant, E.; Andersson, P.; Stewart, T.; Nelson, S.; Fischbein, N.; Coyle, P.K.; Frohman, E.; et al. A phase I trial of solubilized DR2:MBP84-102 (AG284) in multiple sclerosis. Neurology 2000, 54, 1414-1420. [CrossRef] [PubMed]

219. Warren, K.G.; Catz, I.; Ferenczi, L.Z.; Krantz, M.J. Intravenous synthetic peptide MBP8298 delayed disease progression in an HLA Class II-defined cohort of patients with progressive multiple sclerosis: Results of a 24-month double-blind placebo-controlled clinical trial and 5 years of follow-up treatment. Eur. J. Neurol. 2006, 13, 887-895. [CrossRef]

220. Freedman, M.S.; Bar-Or, A.; Oger, J.; Traboulsee, A.; Patry, D.; Young, C.; Olsson, T.; Li, D.; Hartung, H.-P.; Krantz, M.; et al. A phase III study evaluating the efficacy and safety of MBP8298 in secondary progressive MS. Neurology 2011, 77, 1551-1560. [CrossRef]

221. Offner, H.; Burrows, G.G.; Ferro, A.J.; Vandenbark, A.A. RTL therapy for multiple sclerosis: A Phase I clinical study. J. Neuroimmunol. 2011, 231, 7-14. [CrossRef]

222. Yadav, V.; Bourdette, D.N.; Bowen, J.D.; Lynch, S.G.; Mattson, D.; Preiningerova, J.; Bever, C.T.; Simon, J.; Goldstein, A.; Burrows, G.G.; et al. Recombinant T-cell receptor ligand (RTL) for treatment of multiple sclerosis: A double-blind, placebo-controlled, Phase 1, dose-escalation study. Autoimmune Dis. 2012, 2012, 954739. [CrossRef]

223. Loo, E.W.; Krantz, M.J.; Agrawal, B. High dose antigen treatment with a peptide epitope of myelin basic protein modulates T cells in multiple sclerosis patients. Cell. Immunol. 2012, 280, 10-15. [CrossRef]

224. Lutterotti, A.; Yousef, S.; Sputtek, A.; Stürner, K.H.; Stellmann, J.-P.; Breiden, P.; Reinhardt, S.; Schulze, C.; Bester, M.; Heesen, C.; et al. Antigen-specific tolerance by autologous myelin peptide-coupled cells: A Phase 1 trial in multiple sclerosis. Sci. Transl. Med. 2013, 5, 188ra75. [CrossRef]

225. Bar-Or, A.; Vollmer, T.; Antel, J.; Arnold, D.L.; Bodner, C.A.; Campagnolo, D.; Gianettoni, J.; Jalili, F.; Kachuck, N.; Lapierre, Y.; et al. Induction of antigen-specific tolerance in multiple sclerosis after immunization with a DNA encoding myelin basic protein in a randomized, placebo-controlled Phase I/II trial. Arch. Neurol. 2007, 64, 1407-1415. [CrossRef] [PubMed] 
226. Juryńczyk, M.; Walczak, A.; Jurewicz, A.; Jesionek-Kupnicka, D.; Szczepanik, M.; Selmaj, K. Immune regulation of multiple sclerosis by transdermally applied myelin peptides. Ann. Neurol. 2010, 68, 593-601. [CrossRef] [PubMed]

227. Walczak, A.; Siger, M.; Ciach, A.; Szczepanik, M.; Selmaj, K. Transdermal application of myelin peptides in multiple sclerosis treatment. JAMA Neurol. 2013, 70, 1105-1109. [CrossRef] [PubMed]

228. Garren, H.; Robinson, W.H.; Krasulova', E.; Havrdova', E.; Nadj, C.; Selmaj, K.; Losy, J.; Nadj, I.; Radue, E.-W.; Kidd, B.A.; et al. Steinman, and the BHT-3009 Study Group, Phase 2 trial of a DNA vaccine encoding myelin basic protein for multiple sclerosis. Ann. Neurol. 2008, 63, 611-620. [CrossRef]

229. Papadopoulou, A.; von Felten, S.; Traud, S.; Rahman, A.; Quan, J.; King, R.; Garren, H.; Steinman, L.; Cutter, G.; Kappos, L.; et al. Evolution of MS lesions to black holes under DNA vaccine treatment. J. Neurol. 2012, 259, 1375-1382. [CrossRef]

230. Chataway, J.; Martin, K.; Barrell, K.; Sharrack, B.; Stolt, P.; Wraith, D.C. Effects of ATX-MS-1467 immunotherapy over 16 weeks in relapsing multiple sclerosis. Neurology 2018, 90, e955-e962. [CrossRef]

231. Zubizarreta, I.; Flórez-Graub, G.; Vila, G.; Cabezón, R.; España, C.; Andorra, M.; Saiza, A.; Llufriu, S.; Sepulveda, M.; Sola-Valls, N.; et al. Immune tolerance in multiple sclerosis and neuromyelitis optica with peptide-loaded tolerogenic dendritic cells in a phase $1 \mathrm{~b}$ trial. Proc. Natl. Acad. Sci. USA 2019, 116, 8463-8470. [CrossRef]

232. Willekens, B.; Presas-Rodríguez, S.; Mansilla, M.J.; Derdelinckx, J.; Lee, W.-P.; Nijs, G.; de Laere, M.; Wens, I.; Cras, P.; Parizel, P.; et al. On behalf of the RESTORE consortium, Tolerogenic dendritic cell-based treatment for multiple sclerosis (MS): A harmonized study protocol for two phase I clinical trials comparing intradermal and intranodal cell administration. BMJ Open 2019, 9, e030309. [CrossRef]

233. Seledtsova, G.V.; Ivanova, I.P.; Shishkov, A.A.; Seledtsov, V.I. Immune responses to polyclonal T-cell vaccination in patients with progressive multiple sclerosis. J. Immunotoxicol. 2016, 13, 879-884. [CrossRef]

234. Loftus, B.; Newsom, B.; Montgomery, M.; von Gynz-Rekowski, K.; Riser, M.; Inman, S.; Garces, P.; Rill, D.; Zhang, J.; Williams, J.C. Autologous attenuated T-cell vaccine (Tovaxin ${ }^{\circledR}$ ) dose escalation in multiple sclerosis relapsing-remitting and secondary progressive patients nonresponsive to approved immunomodulatory therapies. Clin. Immunol. 2009, 131, 202-215. [CrossRef]

235. Fox, E.; Wynn, D.; Cohan, S.; Rill, D.; McGuire, D.; Markowitz, C. A randomized clinical trial of autologous T-cell therapy in multiple sclerosis: Subset analysis and implications for trial design. Mult. Scler. J. 2012, 18, 843-852. [CrossRef] [PubMed]

236. Karussis, D.; Shor, H.; Yachnin, J.; Lanxner, N.; Amiel, M.; Baruch, K.; Keren-Zur, Y.; Haviv, O.; Filippi, M.; Petrou, P.; et al. T Cell vaccination benefits relapsing progressive multiple sclerosis patients: A randomized, double-blind clinical trial. PLoS ONE 2012, 7, e50478. [CrossRef] [PubMed]

237. Van der, A.A.; Hellings, N.; Medaer, R.; Gelin, G.; Palmers, Y.; Rauss, J.; Stinissen, P. T cell vaccination in multiple sclerosis patients with autologous CSF-derived activated T cells: Results from a pilot study. Clin. Exp. Immunol. 2003, 131, 155-168. [CrossRef] [PubMed]

238. Zhang, J.Z.; Rivera, V.M.; Tejada-Simon, M.V.; Yang, D.; Hong, J.; Li, S.; Haykal, H.; Killian, J.; Zang, Y.C.Q. T cell vaccination in multiple sclerosis: Results of a preliminary study. J. Neurol. 2002, 249, 212-218. [CrossRef] [PubMed]

239. Correale, J.; Lunda, B.; McMillan, M.; Koa, D.Y.; McCarthy, K.; Weiner, L.P. T cell vaccination in secondary progressive multiple sclerosis. J. Neuroimmunol. 2000, 107, 130-139. [CrossRef]

240. Achiron, A.; Lavie, G.; Kishner, I.; Stern, Y.; Sarova-Pinhas, I.; Ben-Aharon, T.; Barak, Y.; Raz, H.; Lavie, M.; Barliya, T.; et al. $\mathrm{T}$ cell vaccination in multiple sclerosis relapsing-remitting nonresponders patients. Clin. Immunol. 2004, 113, 155-160. [CrossRef]

241. Zang, Y.C.Q.; Hong, J.; Rivera, V.M.; Killian, J.; Zhang, J.Z. Preferential recognition of TCR hypervariable regions by human anti-idiotypic T cells induced by T cell vaccination. J. Immunol. 2000, 164, 4011-4017. [CrossRef]

242. Vandenbark, A.A.; Culbertson, N.E.; Bartholomew, R.M.; Huan, J.; Agotsch, M.; LaTocha, D.; Yadav, V.; Mass, M.; Whitham, R.; Lovera, J.; et al. Therapeutic vaccination with a trivalent T-cell receptor (TCR) peptide vaccine restores deficient FoxP3 expression and TCR recognition in subjects with multiple sclerosis. Immunology 2007, 123, 66-78. [CrossRef]

(C) 2020 by the authors. Licensee MDPI, Basel, Switzerland. This article is an open access article distributed under the terms and conditions of the Creative Commons Attribution (CC BY) license (http://creativecommons.org/licenses/by/4.0/). 